PUBLICATIONS

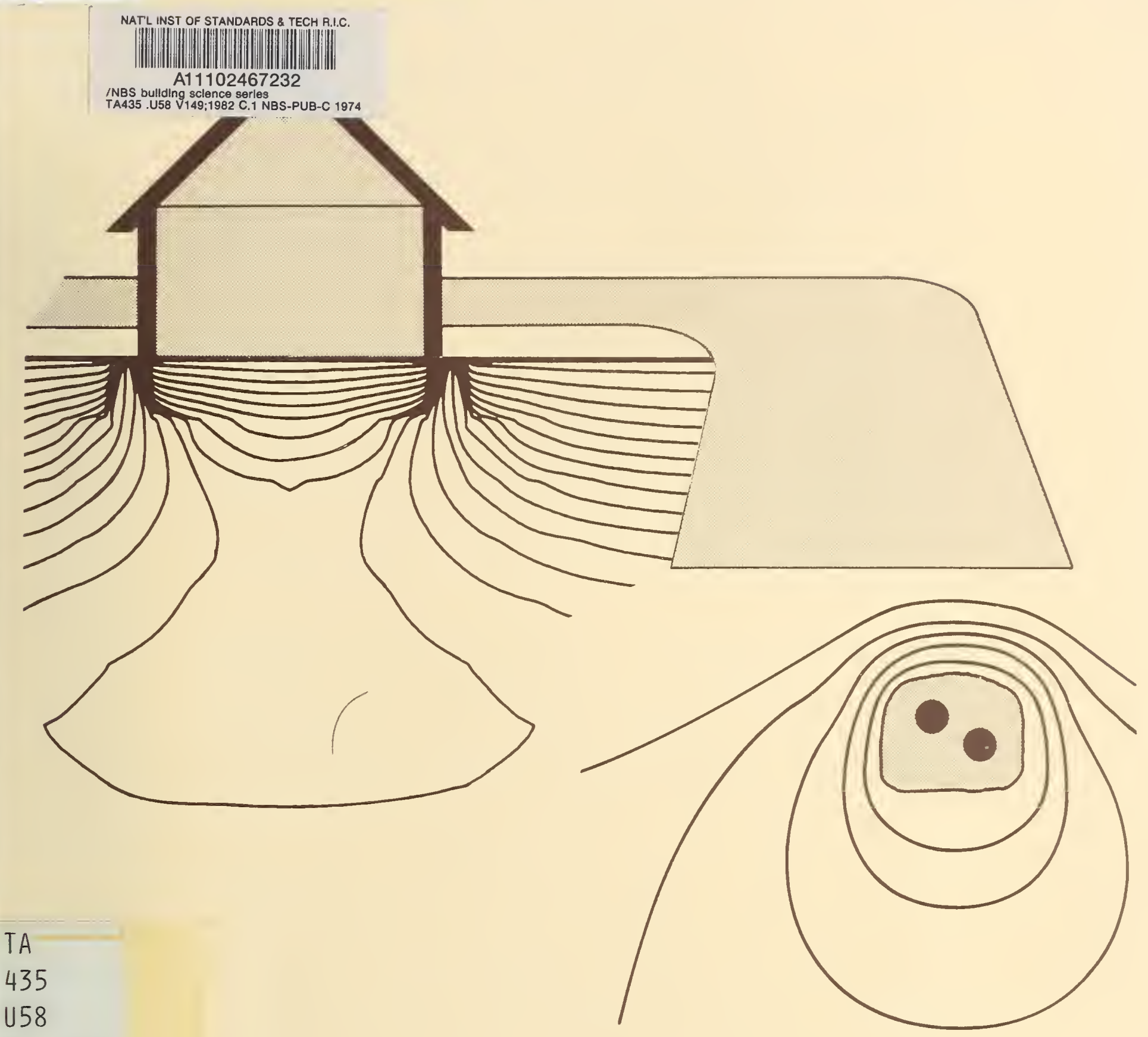

No. 149

1982

C. 2

NBS BUILDING SCIENCE SERIES BSS 149

\title{
Thermal Behavior of Fine-Grained Soils
}




\section{NATIONAL BUREAU OF STANDARDS}

The National Bureau of Standards' was established by an act of Congress on March 3, 1901. The Bureau's overall goal is to strengthen and advance the Nation's science and technology and facilitate their effective application for public benefit. To this end, the Bureau conducts research and provides: (1) a basis for the Nation's physical measurement system, (2) scientific and technological services for industry and government, (3) a technical basis for equity in trade, and (4) technical services to promote public safety. The Bureau's technical work is performed by the National Measurement Laboratory, the National Engineering Laboratory, and the Institute for Computer Sciences and Technology.

THE NATIONAL MEASUREMENT LABORATORY provides the national system of physical and chemical and materials measurement; coordinates the system with measurement systems of other nations and furnishes essential services leading to accurate and uniform physical and chemical measurement throughout the Nation's scientific community, industry, and commerce; conducts materials research leading to improved methods of measurement, standards, and data on the properties of materials needed by industry, commerce, educational institutions, and Government; provides advisory and research services to other Government agencies; develops, produces, and distributes Standard Reference Materials; and provides calibration services. The Laboratory consists of the following centers:

\section{Absolute Physical Quantities ${ }^{2}$ - Radiation Research - Chemical Physics - Analytical Chemistry - Materials Science}

THE NATIONAL ENGINEERING LABORATORY provides technology and technical services to the public and private sectors to address national needs and to solve national problems; conducts research in engineering and applied science in support of these efforts; builds and maintains competence in the necessary disciplines required to carry out this research and technical service; develops engineering data and measurement capabilities; provides engineering measurement traceability services; develops test methods and proposes engineering standards and code changes; develops and proposes new engineering practices; and develops and improves mechanisms to transfer results of its research to the ultimate user. The Laboratory consists of the following centers:

Applied Mathematics - Electronics and Electrical Engineering ${ }^{2}$ - Manufacturing Engineering - Building Technology - Fire Research - Chemical Engineering ${ }^{2}$

THE INSTITUTE FOR COMPUTER SCIENCES AND TECHNOLOGY conducts research and provides scientific and technical services to aid Federal agencies in the selection, acquisition, application, and use of computer technology to improve effectiveness and economy in Government operations in accordance with Public Law 89-306 (40 U.Ś.C. 759), relevant Executive Orders, and other directives; carries out this mission by managing the Federal Information Processing Standards Program, developing Federal ADP standards guidelines, and managing Federal participation in ADP voluntary standardization activities; provides scientific and technological advisory services and assistance to Federal agencies; and provides the technical foundation for computer-related policies of the Federal Government. The Institute consists of the following centers:

Programming Science and Technology-Computer Systems Engineering.

'Headquarters and Laboratories at Gaithersburg, MD, unless otherwise noted;

mailing address Washington, DC 20234.

${ }^{2}$ Some divisions within the center are located at Boulder, CO 80303. 


\section{Thermal Behavior of Fine-Grained Soils}

Lawrence A. Salomone

William D. Kovacs

Herbert Wechsler

Center for Building Technology

National Engineering Laboratory

National Bureau of Standards

Washington, DC 20234

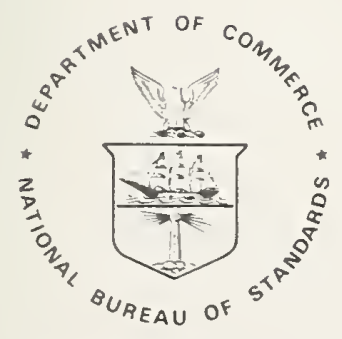

U.S. DEPARTMENT OF COMMERCE, Malcolm Baldrige, Secretary NATIONAL BUREAU OF STANDARDS, Ernest Ambler, Director

Issued November 1982 
Library of Congress Catalog Card Number: 82-600636

National Bureau of Standards Building Science Series 149

Natl. Bur. Stand. (U.S.), Bldg. Sci. Ser. 149, 102 pages (Nov. 1982)

CODEN: BSSNBV

\section{U.S. GOVERNMENT PRINTING OFFICE}

WASHINGTON: 1982

Washington, D.C. 20402 - Price $\$ 5.50$ 


\section{ABSTRACT}

Laboratory thermal probe tests performed on an AASHTO standard reference material (a silty clay) showed that thermal resistivity $\left({ }^{\circ} \mathrm{C} \cdot \mathrm{cm} / w a t t\right)$ varies with soil moisture content and dry density. The tests were performed to correlate soil thermal behavior with the limit states of fine-grained soils. Over 80 thermal resistivity measurements were rade on specimens compacted to various densities and moisture contents.

Results are presented which indicate that the optimum moisture content of solls and the Atterberg Limits can be correlated with the thermal behavior of finegrained soils. It was found that the mininum therinal resistivity (i.e. the critical moisture content) occurred at the optimum moisture content when the soils were compacted using various compactive efforts. The critical moisture content defines the knee of the thermal resistivity versus moisture content curve. When the soils were compacted using a compactive effort of $1.42 \times 10^{5}$ $\mathrm{J} / \mathrm{m}^{3}$ ( $2970 \mathrm{ft}-1 \mathrm{bs}$ per cubic foot), the mininum thermal resistivity occurred at the plastic limit of the AASHTO standard reference material. Also, indices are defined which allow comparison of the thermal behavior of fine-grained solis.

Keywords: Atterberg 1 imit tests; compaction; compaction tests; heat flow; laboratory tests; soll molsture; soll tests; tests; thermal conductivity; thermal resistivity.

COVER: Temperature contours beneath a house and around underground electric transmission lines. 


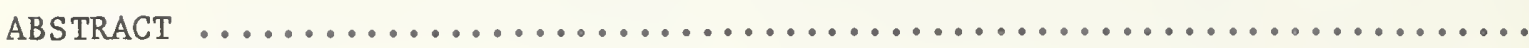

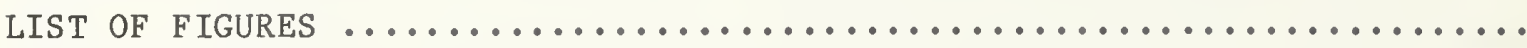

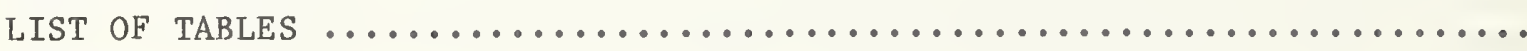

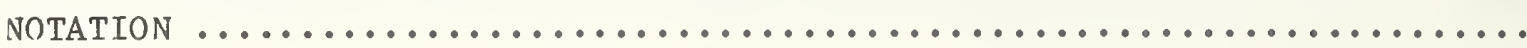

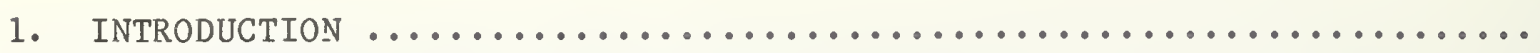

1.1 GENERAL ...........................................

1.2 LIMITATIONS OF PRESENT PROCEDURES USED TO EVALUATE THERMAL

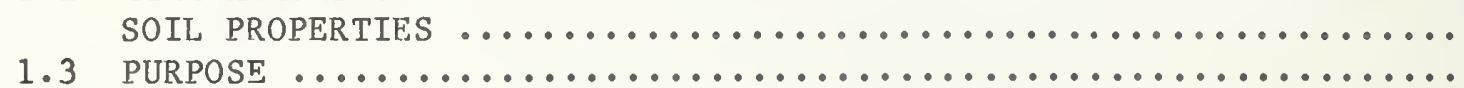

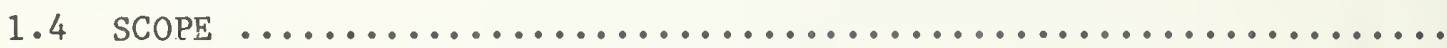

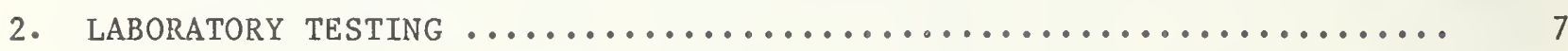

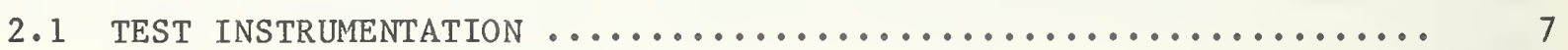

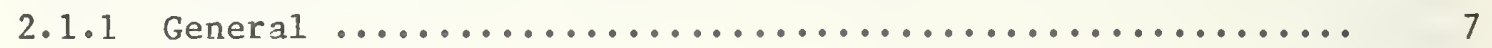

2.1 .2 Thermal probes .................................. 8

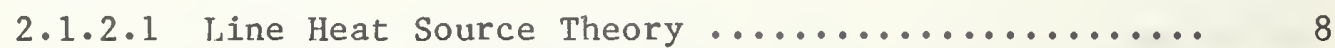

2.1.3 EPRI Thermal Property Analyzer ....................... 9

2.2 DESCRIPTION OF AMRL REFERENCE SOIL ........................ 10

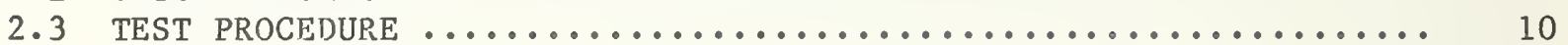

2.3 .1 General ......................................... 10

2.3.2 Selection of Molding Moisture Content ............... 11

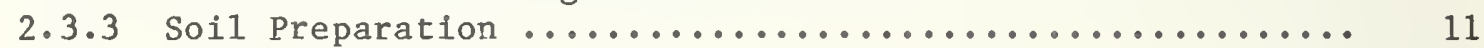

2.3.4 Sample Preparation ................................ 12

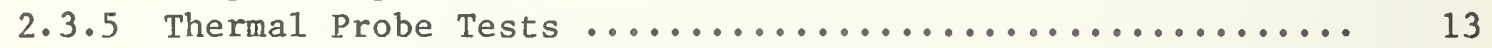

2.3.6 Moisture and Density Determinations ................. 14

3. THEORETICAL CONSIDERATIONS AFFECTING THERMAL PERFORMANCE OF SOILS ... 19

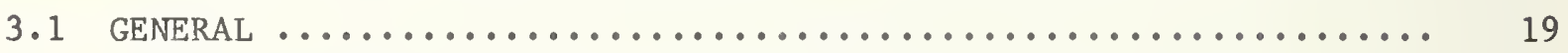

3.2 PRIMARY FACTORS AFFECTING THE THERMAL RESISTIVITY OF SOILS .... 20

3.2.1 Soil Composition ................................ 20

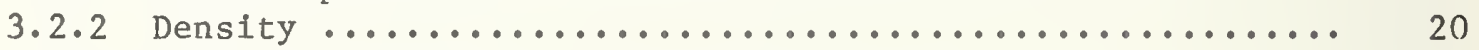

3.2.3 Moisture Content .................................. 21

3.3 ASSESSING THE ENGINEERING PROPERTIES OF SOILS ............... 22

3.4 DETERMINING THE THERMAL BEHAVIOR OF SOILS ................. 24

3.4 .1 Genera1 ........................................ 24

3.4 .2 Approach ..................................... 24

4. PRESENTATION AND DISCUSSION OF TEST RESULTS ................... 31

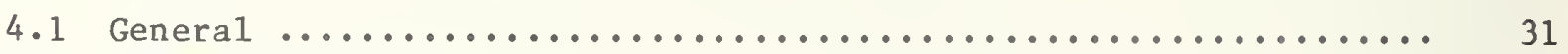

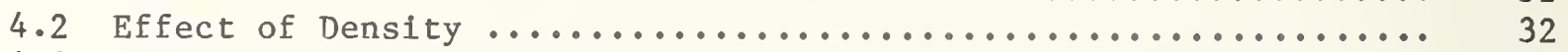

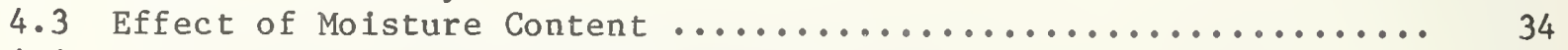

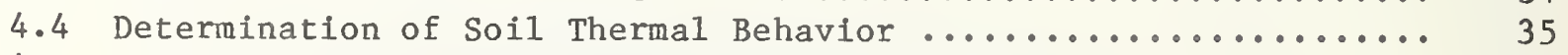

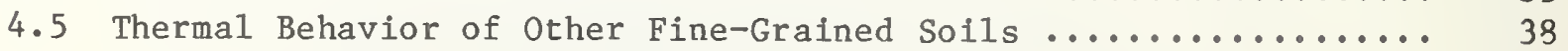


TABLE OF CONTENTS (Continued)

Page

5.

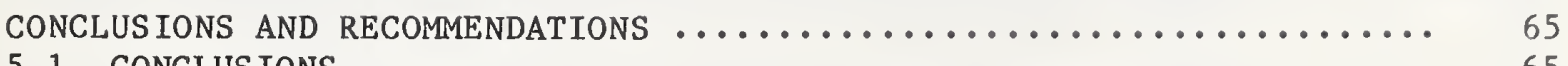

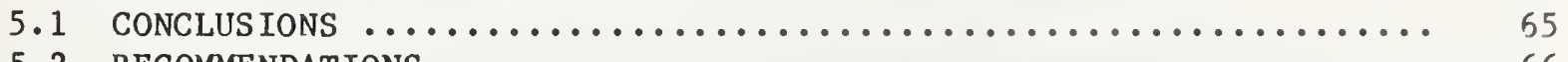

$$
\begin{aligned}
& 5.2 \text { RECOMMENDATIONS } \\
& 66
\end{aligned}
$$

6. ACKNOWLEDGMENTS

67

7. REFERENCES

69

8. APPENDIX A - TABULATION OF DATA

An

v 
Figure 1-1. A qualitative comparison of the differences in terminology used by agronomists and geotechnical engineers ..........

Figure 1-2. Correlation of thermal resistivity with the Atterberg



Figure 2-1. Sectional view of a laboratory thermal probe .......... 16

Figure 2-2. Front-panel layout of EPRI Thermal Property Analyzer ...... 17

Figure 3-1. The effect of soll molsture on the heat flow path ....... 26

Figure 3-2. The effect of moisture content and dry density on the thermal resistivity of soils $\ldots \ldots \ldots \ldots \ldots \ldots \ldots \ldots \ldots \ldots$

Figure 3-3. Soll molsture scale showing soil moisture terms used by

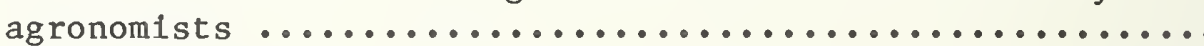

Figure 3-4. Soil moisture scale showing soil moisture terms (Atterberg Limits) used by geotechnical engineers for fine-grained

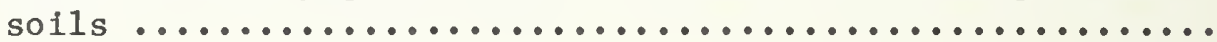

Figure 3-5. Molsture content continuum showing the various states of fine-grained solls and the generalized stress-strain



Figure 4-1. Variation of thermal resistivity with molsture content and dry density for AMRL Reference Soil ................

Figure 4-2. Variation of thermal conductivity with dry density for

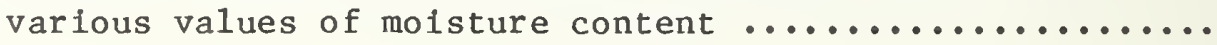

Figure 4-3. Variation of thermal resistivity with dry density for molsture contents of 3 percent to $18-1 / 2$ percent .........

Figure 4-4. Variation of thermal resistivity with dry density for molsture contents of 21 percent to $50-1 / 2$ percent .......

Figure 4-5. Variation of thermal conductivity with moisture content for various values of dry density ................. 45

Figure 4-6. Diagram of thermal conductivity for AMRL reference soil .... 46

Figure 4-7. Compaction curves for modified, standard, and s6 energies ..

Figure 4-8. Correlation of modified energy moisture - density curve with thermal resistivity - moisture content curve ....... 
Figure 4-9. Correlation of intermediate energy molsture - density curve with thermal resistivity - molsture content

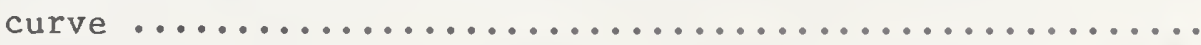

Figure 4-10. Correlation of standard plus energy moisture - density curve with thermal resistivity - molsture content

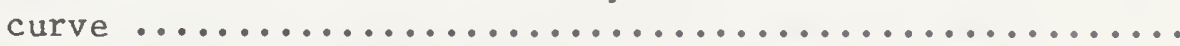

Figure 4-11. Correlation of standard energy moisture - density curve with thermal resistivity - moisture content curve ......

Figure 4-12. Correlation of S12 energy moisture - density curve with thermal resistivity - moisture content curve ..........

Figure 4-13. Correlation of S6 energy moisture - density curve with thermal resistivity - moisture content curve .........

Figure 4-14. Correlation of S4 energy moisture - density curve with thermal resistivity - moisture content curve .........

Figure 4-15. Variation of minimum thermal resistivity with compactive

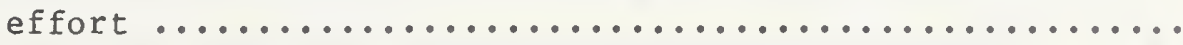

Figure 4-16. Correlation of thermal resistivity and Atterberg Limit test data using $\mathrm{S} 6$ compactive effort $\ldots \ldots \ldots \ldots \ldots \ldots$

Figure 4-17. Thermal behavior of AMRL reference soil sample using S6

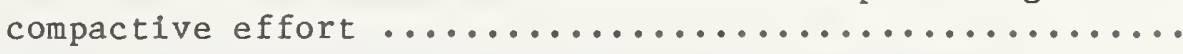

Figure 4-18 Georgia clay thermal resistivity test data .......... 58

Figure 4-19. Niagara clay thermal resistivity test data ............ 59

Figure 4-20. Northway silt loam thermal resistivity test data

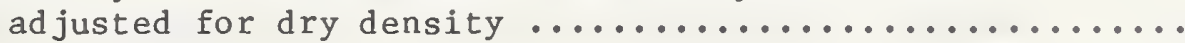

Figure 4-21. Fairbanks silt loam thermal resistivity test data

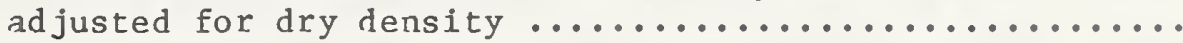

Figure 4-22. Fairbanks silty clay loam thermal resistivity test data

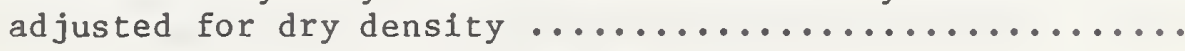

Figure 4-23. Healy clay thermal resistivity test data adjusted for

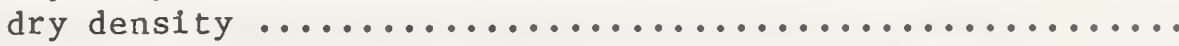

Figure 4-24. Ramsey sandy loam thermal resistivity test data adjusted

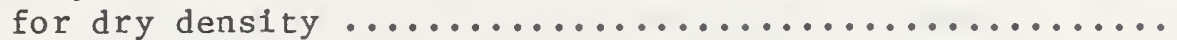


LIST OF TABLES

$\underline{\text { Page }}$

Table 2-1. Summary of Index Property Test Data, AMRL Soil Reference

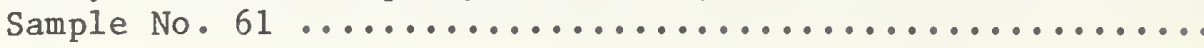

Table 2-2. Summary of Compactive Efforts Used During Laboratory

Testing Program

Table $3-1$. Textural and Other Characteristics of Soils ............

Table 4-1. Thermal Conductivity - Density Relationships ............

Table 4-2. Thermal Conductivity - Moisture Content Relationships ......

Table 4-3. Thermal Performance Regions of AMRL Reference Soil ........

Table 4-4. Thermal Stability Index for AMRL Reference Soil .........

Table 4-5. Correlation of Critical Moisture Content and Optimum Moisture Content for Other Fine-Grained Soils ..........

Table 4-6. Correlation of Critical Moisture Content and Plastic



Table A-1. Summary of Laboratory Test Data, Modified Compaction

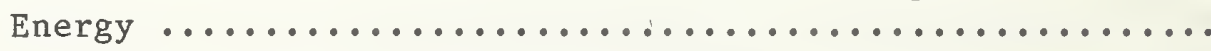

Table A-2. Summary of Laboratory Test Data, Intermediate Compaction

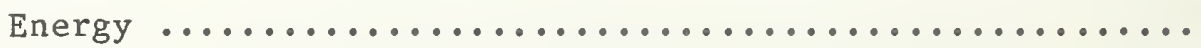

$A-3$

Table A-3. Summary of Laboratory Test Data, Standard Plus Compaction

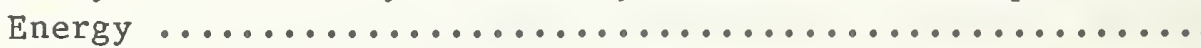

$A-4$

Table A-4. Summary of Laboratory Test Data, Standard Compaction

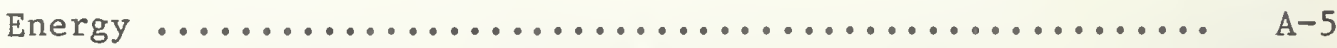

Table A-5. Summary of Laboratory Test Data, S12 Compaction Energy .... A-6

Table A-6. Summary of Laboratory Test Data, S6 Compaction Energy ..... A-7

Table A-7. Summary of Laboratory Test Data, S4 Compaction Energy ...... A-8

Table A-8. Computed Values for the Zero Air Voids Curve for

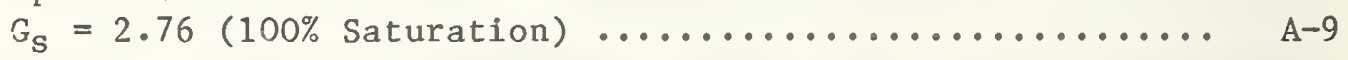

Table A-9. Summary of Moisture Content Data, Modified Compaction Energy ................................ A-10

Table A-10. Summary of Moisture Content Data, Intermediate Compaction Energy .......................... A-10 
Table-A-11. Summary of Moisture Content Data, Standard Plus

Compaction Energy ........................ $4-11$

Table A-12. Summary of Molsture Content Data, Standard Compaction

Energy ................................ $\mathrm{A}-11$

Table A-13. Summary of Moisture Content Data, S12 Compaction Energy .... A-12

Table A-14. Summary of Moisture Content Data, S6 Compaction Energy ..... A-13

Table A-15. Summary of Molsture Content Data, 54 Compaction Energy ..... A-14

Table A-16. Moisture Loss (Gain) of the Test Samples During the

Thermal Probe Test, Modified Compaction Energy ......... A-15

Table A-17. Moisture Loss (Gain) of the Test Samples During the

Thermal Probe Test, Intermediate Compaction Energy ...... A-16

Table A-18. Molsture Loss of the Test Samples During the Thermal

Probe Test, Standard Plus Compaction Energy ........... A-16

Table A-19. Molsture Loss (Gain) of the Test Samples During the

Thermal Probe Test, Standard Compaction Energy ........ A-17

Table A-20. Molsture Loss of the Test Samples During the Thermal

Probe Test, 112 Compaction Energy ...................... A-17

Table A-21. Moisture Loss (Gain) of the Test Samples During the

Thermal Probe Test, s6 Compaction Energy ............. A-18

Table A-22. Moisture Loss of the Test Samples During the Thermal

Probe Test, 54 Compaction Energy ..................... A-19 


\section{NOTATION}

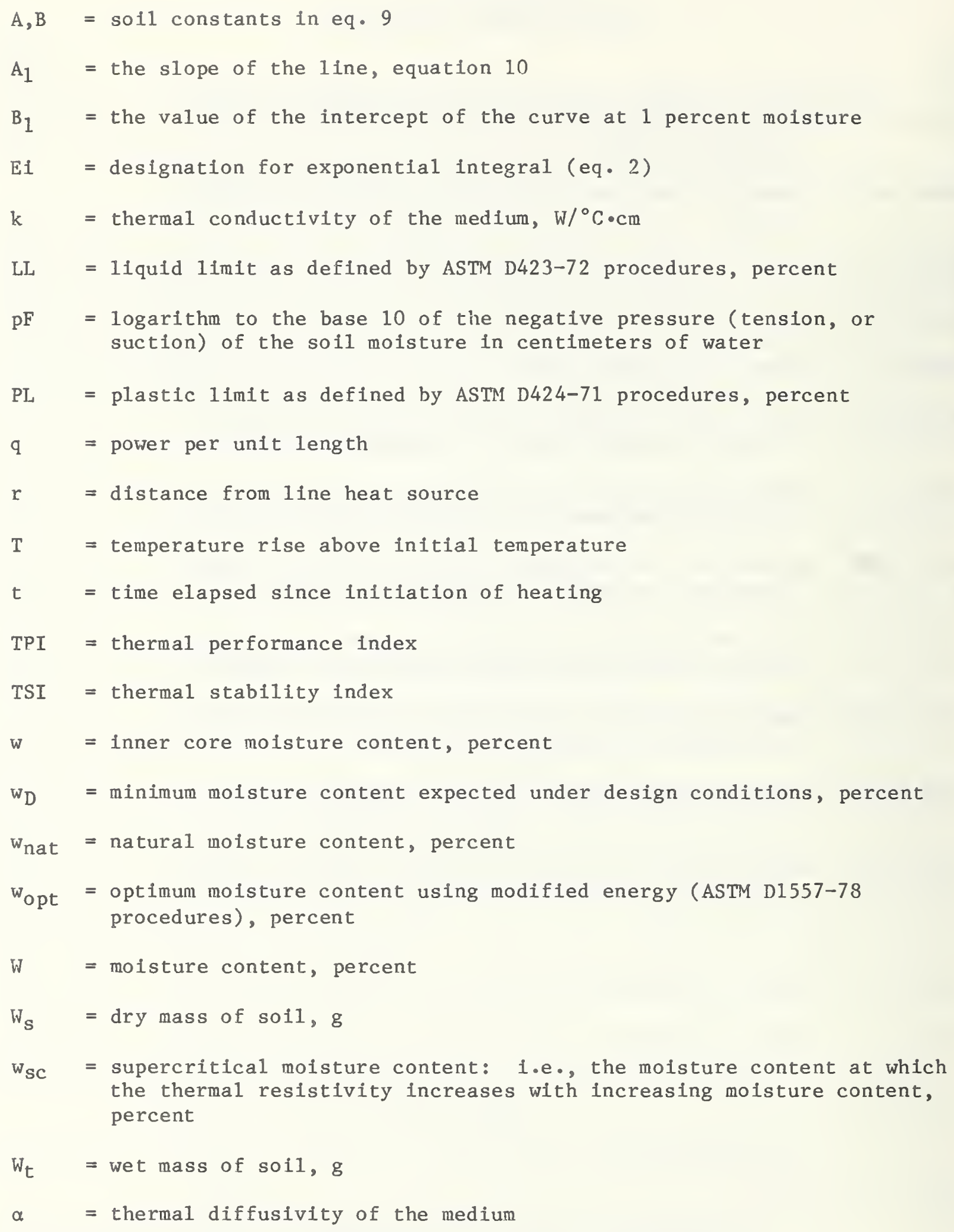


$\gamma \quad=$ Euler's constant $=0.5772$

$\rho_{\mathrm{d}} \quad=$ dry density, $\mathrm{Mg} / \mathrm{m}^{3}$

$\rho_{\mathrm{M}} \quad=$ thermal resistivity of a sample prepared using modified energy (ASTM D 1557-78 procedures) and a moisture content equal to the modified optimum moisture content, ${ }^{\circ} \mathrm{C} \cdot \mathrm{cm} / \mathrm{W}$

$\rho_{\mathrm{S}} \quad=$ thermal resistivity of a sample prepared using standard energy (ASTM D 698-78 procedures) and a moisture content equal to the 1iquid 1 imit, ${ }^{\circ} \mathrm{C} \cdot \mathrm{cm} / \mathrm{W}$ 
FACING PAGE: Sample compacted using the 102-mm (4-in) mold and the 5.5-1 bf $(2.49-\mathrm{kg})$ hammer according to ASTM D698-78 procedures. 




\section{INTRODUCTION}

\subsection{GENERAL}

Evaluation of the thermal properties of solls is a problem facing many geotechnical engineers. Selection of suitable backfill soils for nuclear waste disposal sites requires a thorough knowledge of the thermal properties of the material that surrounds the contalnment areas and of the factors which affect these properties. Likewise, knowledge of the thermal properties of solls is necessary to predict the heat loss in burled structures and in residential housing with slab-on-grade construction. Through an understanding of thermal soil properties, energy savings are being obtalned by using solls 
to moderate the temperature to which a structure is subjected. The importance of evaluating thermal properties of solls surrounding buried electric power cables is evident when one considers that temperatures greater than $50^{\circ} \mathrm{C}$ to $60^{\circ} \mathrm{C}$ may lead to breakdown of burled cable insulation if the soil surrounding the cable is unable to conduct the heat away as it is generated. It is this need to use soil as an insulating material or as a conductor to dissipate heat that requires an understanding of the soil characteristics that affect thermal soil behavior.

In simple terms, solls with a high thermal resistance will not dissipate heat from a heat source as rapidly as low resistivity soils. The thermal resistivity of soil is a measure of the thermal performance of soll. It is the reciprocal of thermal conductivity. The thermal resistivity of the soil is primarily influenced by: soil composition, moisture content and dry density. When it is considered that the resistivity (in thermal ohms*) of quartz is 11 , water 165 and air 4000, the need for examining each of the three phases (solid material, water, and air) and their interrelationship is evident. The laboratory testing program described herein was designed for the purpose of finding low cost, simple, index property tests and defining soil indices that establish the thermal behavior of fine-grained solls.

\subsection{LIMITATIONS OF PRESENT PROCEDURES USED TO EVALUATE THERMAL SOIL PROPERTIES}

Progress in the prediction of thermal soil properties is limited by the fact that relevant information is scattered in a variety of technical fields. Also, authors have not used a common language to describe the results of field and laboratory measurements of these properties.

Geotechnical investigations consisting of in situ and laboratory thermal probe tests, soil sampling and determinations of moisture and density are frequently performed to evaluate the thermal resistivity of soils. These investigations often are conducted using routine procedures adopted over the years, based on research done in the late fifties and early sixties [1], 1 but not necessarily reflecting all the information and techniques now available. Furthermore, much of the valuable work performed by or under the direction of the Power industry in the above periods and on which these procedures are based, is reported in language more familiar to agronomists and electrical engineers [1]. On the other hand, more recent contributions to the state-of-the-art by geotechnical engineers are not documented using similar terminology nor correlated with the findings of the earlier work [2]. This communication barrier limits present progress in the prediction of thermal soll properties because of possible duplication of efforts with earlier researchers and the inability of researchers and engineers to exchange information easily and to compile their accumulated experience using common terminology.

* The thermal ohm is the unit of resistivity. It is defined as the number of degrees centigrade of temperature drop that occurs when heat flows through a 1 centimeter cube at the rate of 1 watt. The unit of thermal resistivity is ${ }^{\circ} \mathrm{C} \cdot \mathrm{cm} / \mathrm{W}$. Note: $100^{\circ} \mathrm{C} \cdot \mathrm{cm} / \mathrm{W}=1{ }^{\circ} \mathrm{K} \cdot \mathrm{m} / \mathrm{W}$ and $.01731^{\circ} \mathrm{C} \cdot \mathrm{cm} / \mathrm{W}=1 \mathrm{hr} \cdot \mathrm{ft} \cdot{ }^{\circ} \mathrm{F} / \mathrm{Btu}$.

1 Numbers in brackets indicate the 1iterature references at the end of the paper. 
The key to improving our predictive capability in the fleld of thermal soll mechanics is to have a thorough understanding of the soll characteristics that affect soll thermal behavior and to use this knowledge to develop a common language which will eliminate the communication barrier.

\subsection{PURPOSE}

The purpose of this study is to provide an approach for determining the thermal behavior of fine-grained soils using index property tests.

\subsection{SCOPE}

The index properties of solls (e.g., particle-size distribution and Atterberg Limits) have been found to correlate well with engineering properties (strength, stiffness, and compressibility) of soils [3]. By knowing the index properties of soils, the engineer is able to obtain an indication of the performance of various types of soils under various engineering situations. At the present time index property tests are not used in the field of thermal soll mechanics to provide an indication of the thermal performance of various types of solls. This is true even though tests, which measure the changes in the state of soll relative to changes in moisture content, could provide an indication of thermal soll behavior as a result of the influence of molsture content on the thermal resistivity of soil. Identification of index property tests to achieve this purpose was accomplished in this study by:

1. Examining those soll molsture concepts from the flelds of agronomy and geotechnical engineering, that were considered applicable to understanding better the Atterberg Limits (i.e. the limit states of soil behavior).

2. Measuring the thermal resistivity of a fine-grained soil whose index properties were known from the AASHTO Materials Reference Laboratory (AMRL) using laboratory thermal probe tests and establishing the relationships of thermal resistivity to moisture content at various densities for this soil. Over 80 thermal resistivity measurements were made on specimens compacted to various moisture contents and densities.

3. Obtaining index property and thermal resistivity test data for fine-grained soils from the literature.

4. Correlating the thermal resistivity test data obtained from 1 tems 2 and 3 above with the agronomy and geotechnical limit states shown in figure 1-1.*

An example of how this can be done is shown in figure 1-2 from Salomone [4] which presents Atterberg Limits and thermal resistivity test data showing the correlation between the Atterberg Limits and soil thermal resistivity for fine-grained soils.

\footnotetext{
* Figures are provided at the end of the section in which they are first cited.
} 


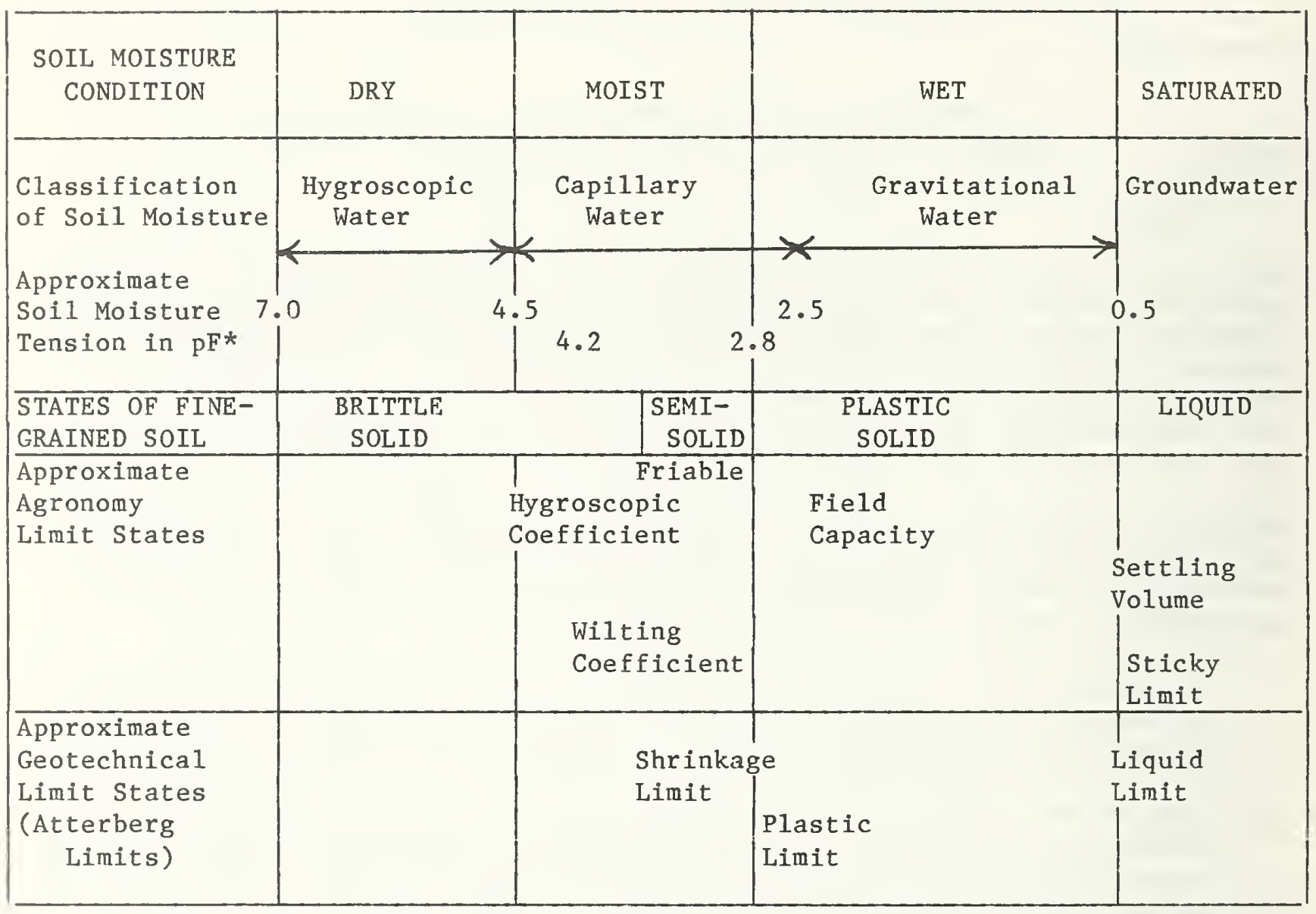

* $\mathrm{pF}$ is the logarithm to the base 10 of the negative pressure (tension, or suction) of the soil moisture in centimeters of water.

Figure 1-1. A qualitative comparison of the differences in terminology used by agronomists and geotechnical engineers (modified from [4]). 


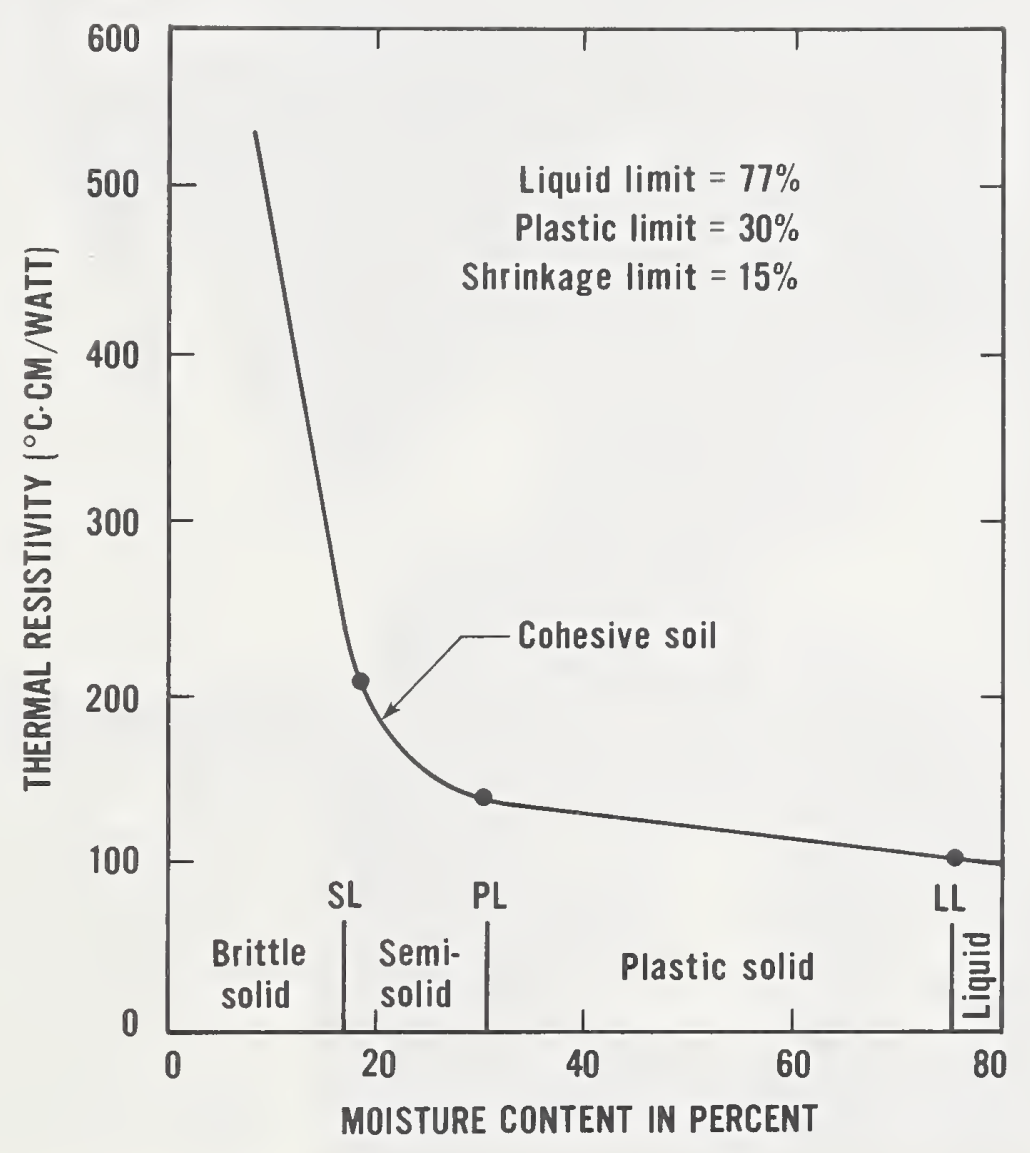

Figure 1-2. Correlation of thermal resistivity with the Atterberg Limits (from [4]). 
FACING PAGE: Using drill press to push laboratory thermal probe into compacted sample. 


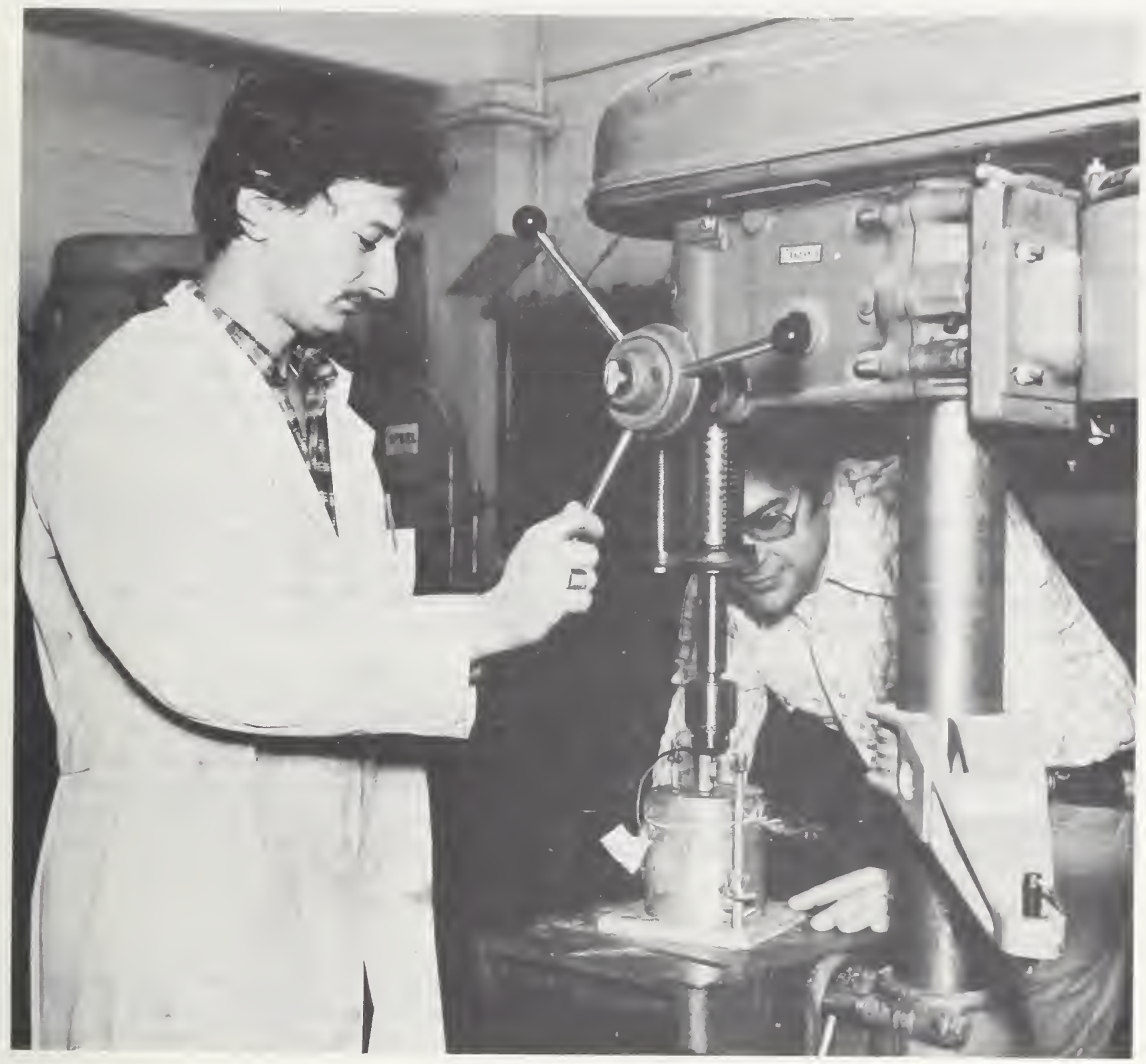

2. LABORATORY TESTING

\subsection{TEST INSTRUMENTATION}

\subsubsection{General}

The equipment used to determine the thermal conductivity (or thermal resistivity) of the laboratory soil samples tested included: 
1. Six laboratory thermal probes, and

2. Electric Power Research Institute (EPRI) Thermal Property Analyzer.*

\subsubsection{Thermal Probes}

Figure 2-1 shows a sectional view of a laboratory thermal probe similar to those used in this study. Because the interpretation of probe readings depends on the validity of line heat source theory, exact specifications of the probe with respect to: uniformity of cross-section along the probe length, thermocouple placement, heater resistance and length, proper insulation against electrical short circuits and mechanical durability must be followed when constructing a thermal probe to comply with the major assumptions of line heat source theory. The theory is based on the assumptions that the heating element is a straight line of infinite length and infinitely small diameter. The heating element is homogeneous and isotropic and is embedded in a homogeneous and isotropic medium of infinite extent. Also, the heating element possesses the same thermal properties as the surrounding medium.

Wechsler [5] has made recommendations about the construction of thermal probes. He also presented an abridged version of the line heat source theory upon which the interpretation of the probe reading is based. For convenience to the reader, Wechsler's [5] presentation of line heat source theory is provided in the next section. This derivation is based on information found in Ref. [6].

\subsubsection{Line Heat Source Theory}

Consider an infinite line source of heat placed in an infinite homogeneous medium initially at uniform temperature. Beginning at time $t=0$, heat is released by this source at a rate q per unit source length. The temperature rise $T$ (above the initial temperature) at a distance $r$ from the line source of heat is given [6] as a function of time $t$ by:

$$
T=\frac{-q}{4 \pi k} \text { Ei }\left(\frac{-r^{2}}{4 a t}\right)
$$

where $k$ is the thermal conductivity and $\alpha$ the thermal diffusivity of the medium and Ei indicates the exponential integral evaluated by eq. 2 [6] and tabulated in the literature [7]:

$$
-E i\left(\frac{-r^{2}}{4 \alpha t}\right)=\int_{\frac{r}{4 \alpha t}}^{\infty} \frac{e^{-u}}{u} d u .
$$

* Trade names are identified to specify adequately the experimental procedures. In no case does such identification imply recommendation or endorsement by the National Bureau of Standards, nor does it imply that the material identified is necessarily the best available for the purpose. 
For large values of time, the exponential integral may be approximated by a series expansion as follows:

$$
-E 1\left(\frac{-r^{2}}{4 \alpha t}\right) \cong \ln \left(\frac{4 \alpha t}{r^{2}}\right)-\left(\frac{r^{2}}{4 \alpha t}\right)+\frac{1}{4}\left(\frac{r^{2}}{4 \alpha t}\right)^{2}+\cdots-\gamma
$$

where $\gamma=$ Euler's constant $=0.5772$. By neglecting the term $\frac{1}{t}$ of first order and higher in equation 3 , and substituting in equation 1 , we obtain:

$$
T=\frac{q}{4 \pi k}\left[\ln \left(\frac{4 \alpha t}{r^{2}}\right)-\gamma\right]
$$

or

$$
T=\frac{q}{4 \pi k}\left[\ln t+\ln \frac{4 \alpha}{r^{2}}-\gamma\right]
$$

For fixed values of $\mathrm{r}$ and $\alpha$, the temperature rise increases logarithmically with time. A plot of temperature rise versus logarithm of time should give a straight line of slope $\frac{q}{4 \pi k}$. This technique is customarily used with the Iine heat source method to evaluate the thermal conductivity. At any point in the medium, the temperature rise $T_{1}$, at time $t_{1}$, is related to the temperature rise $\mathrm{T}_{2}$, at time $t_{2}$, by the following equation:

$$
\mathrm{T}_{2}-\mathrm{T}_{1}=\frac{\mathrm{q}}{4 \pi \mathrm{k}} \ln \left(\frac{\mathrm{t}_{2}}{\mathrm{t}_{1}}\right)
$$

Thus, in theory, it is possible to obtain a conductivity value if the temperature rises at only two experimental times are known. To apply eqs. 4, 5, and 6, sufficient times must be allowed so that the exponential integral is approximately equal to the simple logarithmic expression.

\subsubsection{EPRI Thermal Property Analyzer}

The EPRI Thermal Property Analyzer was developed by Ontario Hydro Research Laboratory under an EPRI contract. A manual for the operation and use of the Thermal Property Analyzer (TPA) was prepared by Ontario Hydro Research Laboratory [8]. This report describes the TPA as follows.

"The TPA consists of an electric current source and a six-input thermocouple reader under microprocessor control, housed in a rugged type of attache case. The front-panel layout is shown in figure 2-2. The probe current is determined on the basis of the resistance/unit length and on the anticipated thermal resistivity to give one of three probe powers per unit length appropriate for soils of high, medium, and low thermal resistivity. The thermal resistivity is calculated by the microprocessor from a least squares fit to time-temperature data collected between 300 and 1000 seconds. A special function keyboard is available so that all parameters such as probe powers, times, etc., can be varied from the pre-set (default) values stored in the microprocessor memory (ROM). An RS 232 interface which is capable of supporting a printer or other digital accessories, along with an appropriate printer to produce hard copy of time- 
temperature data and thermal properties, is provided. During a "run", the elapsed time is continuously displayed along with any one of the thermocouple temperatures, probe power per unit length, or thermal resistivity for any thermocouple input, based on data accumulated to that time in the run. When the reset button is depressed, all six thermocouple inputs are scanner and those without thermocouples attached are ignored in future measurements. If the temperature of any thermocouple goes over $100^{\circ} \mathrm{C}$, the thermal resistivity for input is "frozen" and future data from that input are ignored. If the temperture goes over $140^{\circ} \mathrm{C}$, the probe power is removed to protect the stability of the heater. The entire system is designed to operate on 90-140 V rms sine wave, or 100-160 V rms square wave; 47-65 $\mathrm{Hz}$.

Numerous error-reducing features are incorporated into the software. For example, probe power cannot be initiated until the probe has come to thermal equilibrium with the soil. Also, a coefficient of determination is calculated for the least squares fit, and an error message is sent if the coefficient of determination is less than a predetermined value (0.92). Automation of all aspects of thermal property measurement greatly reduces the likelihood of error in data acquisition and reduction."

\subsection{DESCRIPTION OF AMRL REFERENCE SOIL}

Participants in the AASHTO Soil Reference Sample Program were provided two boxes of Soil Reference Samples. Each box was a separate sample of soil marked with a card stamped either 非1 or 非2. Soil from boxes marked 非1 were used for this study. Each individual test performed by the participating laboratories was conducted by the same operator. However, it was not required that the different tests be conducted by the same person. Participating laboratories performing these tests were asked to report the results of a single determination only, not the average of two or more. All tests were conducted according to the AASHTO Standards Methods and Instructions [9]. The results are summarized in table 2-1 [10].

In general, the soil can be described as a silty clay. The Unified Soil Classification [11] is CL.

\subsection{TEST PROCEDURE}

\subsubsection{General}

The laboratory testing program included:

1. Selection of Molding Moisture Content,

2. Soll Preparation,

3. Thermal Probe Sample Preparation,

4. Thermal Probe Tests, and

5. Moisture and Density Determinations.

The procedures used during each of these steps are described below. 
Table 2-1. Summary of Index Property Test Data

AMRL Soil Reference Sample No. 61 (from [10])

\begin{tabular}{|ll|c|c|c|r|}
\hline \multicolumn{2}{|c}{ TEST TITLE } & & NO. OF & \multicolumn{3}{c|}{ SAMPLE NO.61 } \\
\cline { 5 - 6 } & & LABS & AVERAGE & STAND. DEV. & $\begin{array}{c}\text { C.V. } \\
\text { (PERCENT) }\end{array}$ \\
\hline PASS NO. 10 & PRCNT & 146 & $9.8398+01$ & $1.4415+00$ & 1.465 \\
PASS NO. 40 & PRCNT & 140 & $9.6014+01$ & $1.1897+00$ & 1.239 \\
PASS NO. 200 & PRCNT & 140 & $8.9855+01$ & $1.8107+00$ & 2.015 \\
PASS .02MM & PRCNT & 116 & $8.0406+01$ & $5.0292+00$ & 6.255 \\
PASS .002MM & PRCNT & 116 & $4.5463+01$ & $4.6154+00$ & 10.152 \\
PASS .001MM & PRCNT & 116 & $3.6035+01$ & $4.4790+00$ & 12.430 \\
LIQUID LIMIT & PRCNT & 157 & $4.5121+01$ & $3.6110+00$ & 8.003 \\
PLASTIC LIMIT & PRCNT & 157 & $2.3513+01$ & $1.9520+00$ & 8.302 \\
OPT MOISTURE & PRCNT & 150 & $1.8396+01$ & $1.3899+00$ & 7.555 \\
MAX DENSITY & LB/CF & 152 & $1.0800+02$ & $1.7500+00$ & 1.620 \\
SP GR - NO. 10 & & 125 & $2.7669+00$ & $4.4041-02$ & 1.592 \\
R-VALUE 300 PSI & & 17 & $1.1618+01$ & $6.0396+00$ & 51.986 \\
\hline
\end{tabular}

\subsubsection{Selection of Molding Moisture Content}

The moisture contents for the thermal probe tests were selected initially based on those moisture contents required to establish the moisture-density relationship at compactive efforts of standard $\left(5.92 \times 10^{5} \mathrm{~J} / \mathrm{m}^{3}\right)$ intermediate $\left(16.16 \times 10^{5} \mathrm{~J} / \mathrm{m}^{3}\right)$ and modified $\left(26.93 \times 10^{5} \mathrm{~J} / \mathrm{m}^{3}\right)$ energies. Moisture contents from 17.5 to 32.5 percent at three percent increments were used for each of these compactive efforts until the relationship among moisture-density and compactive efforts were known. With these relationships determined it became apparent that additional compactive efforts were required to obtain samples at a wide range of moisture content and density. The compactive efforts used are summarized in table 2-2 in section 2.3.4. Moisture contents required to determine the relationship of moisture and density for these additional compactive efforts were then selected. With the compaction curves known for the various compactive efforts, the various molding moisture contents (and densities) at which thermal probe tests were to be made were selected by a study of the compaction curves to obtain thermal resistivity test data for a wide range of moisture content and density.

\subsubsection{Soil Preparation}

The soil to be tested was air-dried and a sample was taken to determine the initial moisture content of the air-dried soil. This was used to establish the quantity of water required to produce the molding moisture content.

After the desired moisture content (and density) for a test had been selected, a quantity of air-dried soil equivalent to $2500 \mathrm{~g}$ oven-dry weight (or $2000 \mathrm{~g}$ for 5 of the 56 samples tested at the end of the program) was thoroughly mixed with the necessary amount of water to achieve the molding moisture content. The soil was then stored in an airtight pan for a minimum curing time of 16 
hours to absorb the moisture. To provide a controlled environment for the airtight pan during the curing period, the pan was stored in a plastic bag in which a minimum of $20 \mathrm{~g}$ of water was placed.

\subsubsection{Sample Preparation}

When the soll test sample had completed curing, a compactive effort was selected from those listed in table 2-2, after reviewing the moisture-density data, to achieve the desired density. The equipment used for sample preparation is described in detail in ASTM D 698-78 [Standard Test Methods for Moisture-Density Relations of Soils and Soil-Aggregate Mixtures Using 5.5-1bf (2.49-kg) Rammer and 12-in (305-mm) Drop] and ASTM D 1557-78 [Standard Test Methods for Moisture-Density Relations of Solls and Soil-Aggregate Mixtures Using 10-1bf (4.54 kg) Rammer and 18-in (457-mm) Drop] procedures [12].

The following steps were used to prepare the sample:

a. Placed plastic wrap on the baseplate for the 102-mm (4-in) compaction mold to prevent evaporation of moisture from the bottom of the sample.

b. Attached the mold to the baseplate and recorded the mass on the data sheet to the nearest $0.1 \mathrm{~g}$.

c. Attached the extension collar to the mold.

d. Placed a sufficient amount of the prepared soil in the mold in layers to give a total compacted depth of approximately $130 \mathrm{~mm}$ ( $5 \mathrm{in}$ ). The number of layers, weight of hammer, drop height, and blows per layer used depending on the compactive effort chosen are listed in table 2-2.

e. Removed the extension collar from the mold and removed the exposed compacted soil with a stiff metal straightedge until the surface was even with the top of the mold. The trimmings (i.e., excess soil when preparing the test specimen) were recovered and their moisture content determined.

f. Weighed the mold and baseplate plus wet soil to the nearest tenth of a gram.

g. Covered the sample with plastic wrap to prevent evaporation of moisture from the top of the sample during the thermal probe test. 
Table 2-2. Summary of Compactive Efforts Used During Lahoratory Testing Program

\begin{tabular}{|l|c|c|c|c|c|}
\hline $\begin{array}{c}\text { Weight } \\
\text { of Hammer } \\
(1 \mathrm{bf}) *\end{array}$ & $\begin{array}{c}\text { Fal1 } \\
(\mathrm{ft}) *\end{array}$ & $\begin{array}{c}\text { No.of } \\
\text { Layers }\end{array}$ & $\begin{array}{c}\text { No. of } \\
\text { Blows } \\
\text { per } \\
\text { Layers }\end{array}$ & $\begin{array}{c}\text { Energy } \\
\mathrm{ft} \cdot 1 \mathrm{bf} / \mathrm{ft} 3 *\end{array}$ \\
\hline $\begin{array}{l}\text { Modified } \\
\text { (ASTM D1557-78) }\end{array}$ & 10 & 1.5 & 5 & 25 & 56250 \\
Intermediate & 10 & 1.5 & 3 & 25 & 33750 \\
Standard Plus & 5.5 & 1.0 & 4 & 27 & 17820 \\
Standard \\
(ASTM D698-78)
\end{tabular}

* NOTE: 1 lbf $=4.448 \mathrm{~N}$

$1 \mathrm{ft}=0.3048 \mathrm{~m}$

$1 \mathrm{ft} \cdot 1 \mathrm{bf} / \mathrm{ft}^{3}=47.88 \mathrm{~J} / \mathrm{m}^{3}$

\subsubsection{Thermal Probe Tests}

Laboratory thermal probe tests were performed using the thermal probes described in section 2.1.2 and the EPRI Thermal Property Analyzer described in section 2.1.3. The method of making these tests was changed slightly as experience was gained with this equipment. The procedures that finally evolved are explained below:

a. Plugged in the TPA and printer and turned power switch on. Allowed a minimum of 10 minutes for warm up.

b. Set the $R / L$ ratio (Probe Resistance) of $610 \mathrm{~m} \Omega / \mathrm{cm}(61 \Omega / \mathrm{m})$ by the thumbwheel switches. This is a probe constant which did not change during the testing program.

c. Set the anticipated thermal resistivity to Low (thermal resistivity less than $60^{\circ} \mathrm{C} \cdot \mathrm{cm} /$ watt). This setting provided the highest coefficient of determination for the moist samples tested. For the air dried samples the MEDIUM setting (thermal resistivity between 60 and $120^{\circ} \mathrm{C} \cdot \mathrm{cm} /$ watt) provided the best results. 
d. Set the toggle switch to SINGLE run. SINGLE run indicates one 16 minute-45 second run at a probe power that is determined by step c. A setting of LOW provides a power of 0.359 watt $/ \mathrm{cm}(35.9 \mathrm{w} / \mathrm{m})$ while the MEDIUM setting provides a power of 0.196 watt $/ \mathrm{cm}(19.6 \mathrm{w} / \mathrm{m})$.

e. Inserted the thermal probe into the center of the soil sample using a drill press and in some cases a specially designed cap for the compaction mold to ensure good soil/probe contact. (The drill press and cap aides in preventing lateral movement of the probe as it is inserted into the soil sample.)

f. Connected the probe cables.

g. Depressed the RESET button. This inftiated the thermocouple in the probe being used. (Note that up to six samples can be tested simultaneously.)

h. Waited a minimum of 20 seconds and then pressed RUN button to start the test. The RUN button initiates probe currents and data acquisition.

i. Observed the probe power, thermal resistivity and coefficient of determination for the sample(s) being tested during the run (as required) by using the Data Selector and Thermocouple Selector.

j. Noted the thermal resistivity associated with the highest value of the coefficient of determination recorded by the printer for each sample tested following the 1005 second run.

\subsubsection{Moisture and Density Determinations}

Moisture content and density determinations were performed after the completion of the thermal probe tests using the following approach:

a. Removed plastic wrap from top of sample and weighed the mold and baseplate plus wet soil again to determine moisture loss (gain) during the thermal probe test.

b. Removed a 25-mm (1-in) diameter core of soll from the center of the sample using a 25-mm ( $1-i n)$ diameter thin wall tube and determined the moisture content of the inner soil core using ASTM D 2216-80 [Laboratory Determination of Water (Moisture) Content of Soil, Rock, and Soil-Aggregate Mixtures] procedures [12].

c. Separated the baseplate from the mold.

d. Removed a 51-mm (2-in) diameter core of soil from the center of the sample using a 51-mm (2-in) diameter soil extruder or a 51-mm (2-in) diameter thin wall tube depending on the consistency of the soil to be extruded. The thin wall tube was used for soft soil samples. The moisture content of this outer soil core was determined using ASTM D 2216-80 procedures. 
e. Extruded the remaining soil from the mold using a 102-mm (4-in) diameter soil extruder and determined the molsture content of the sample using ASTM D 2216-80 procedures.

f. Compared the moisture contents for the inner core, outer core, and total sample to determine differences in molsture in the thermal probe test sample.

g. Determined the wet density of the thermal probe test sample using the wet weight of soil determined in step a. and the volume of the mold (measured at the beginning of the testing program).

h. Determined the dry mass of soil using the equation:

$$
W_{s}=\frac{100 W_{t}}{100+w}
$$

where

$$
\begin{aligned}
& W_{s}=\text { dry mass of soil, } g \\
& W_{t}=\text { wet mass of soil, } g \\
& w=\text { inner core moisture content, expressed in percent }
\end{aligned}
$$

i. Determined the dry density of the thermal probe test sample using the dry weight of soil determined in step $h$. and the measured volume of the mold. 


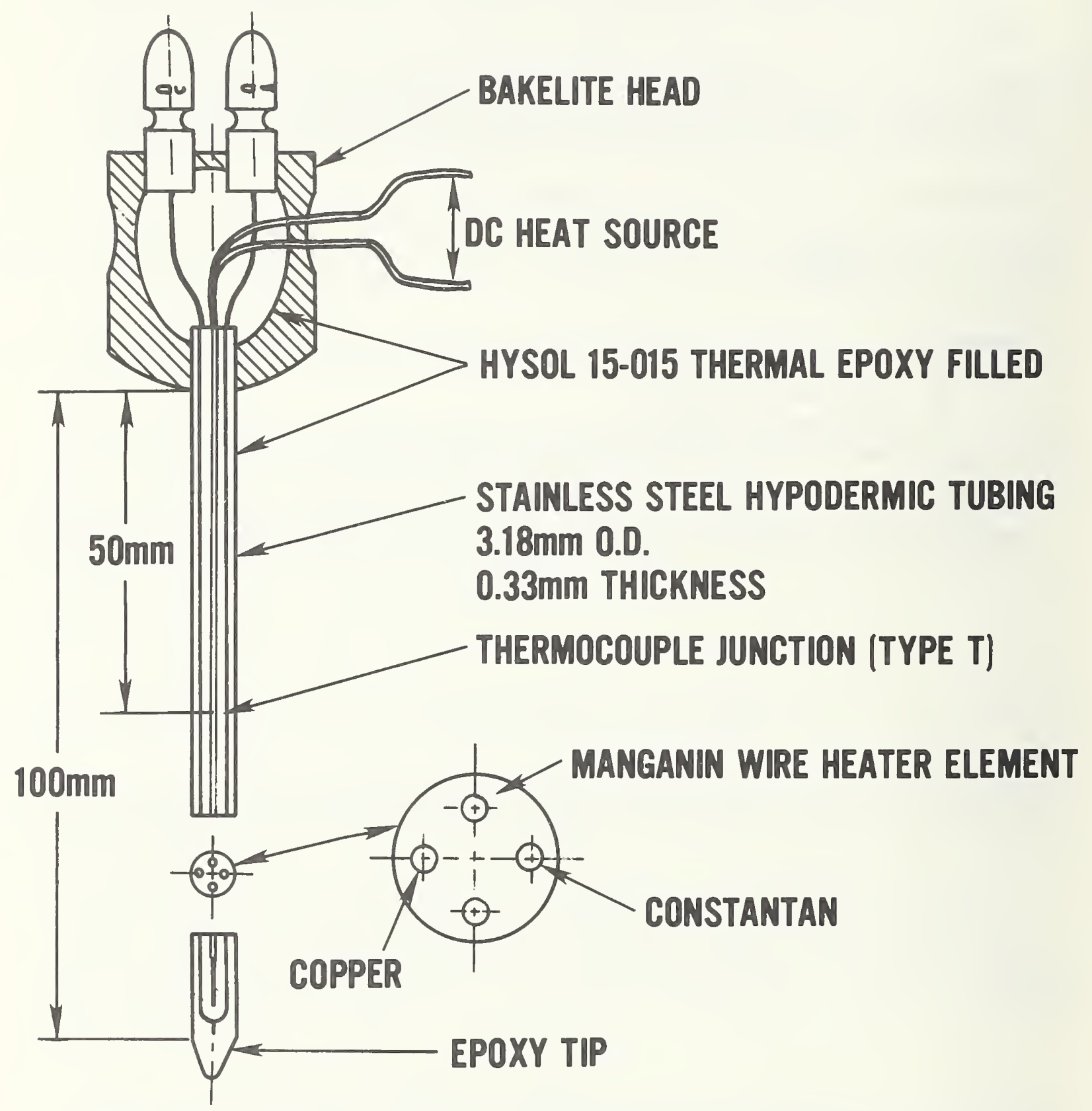

Figure 2-1. Sectional view of a laboratory thermal probe (from [27]) 




Figure 2-2. Front-panel layout of EPRI Thermal Property Analyzer (from [8]) 
FACING PAGE: Connecting the thermal property analyzer to the laboratory thermal probe. 




3. THEORETICAL CONSIDERATIONS AFFECTING THERMAL PERFORMANCE OF SOILS

\subsection{GENERAL}

To provide the readers a better understanding of the findings from this study, a review of the factors affecting thermal resistivity is presented. Techiques used by agronomists and geotechnical engineers to predict soil hehavior that are applicable to this study are discussed. This background information which is derived from Ref. [4] serves as the basis for the discussion of test results in section 4 . 


\subsection{PRIMARY FACTORS AFFECTING THE THERMAL RESISTIVITY OF SOILS}

The thermal resistivity of a soil is primarily influenced by the following parameters:

a. Soil composition,
b. Density, and
c. Moisture content.

The importance of these parameters is discussed below.

\subsubsection{Soil Composition}

Soil is a three-phase medium composed of solid materials (inorganic and/or organic), liquid (water) and gases (air). Because heat flowing through soil must flow through the solid mineral grains and the medium in which they are embedded in a complex system of series and parallel paths, the thermal resistivity of the soil depends on the thermal resistivity of its component materials and the soil structure. This point is important because of the difference in the thermal resistivity of the various components of the medium. The thermal resistivity, in thermal ohms $\left({ }^{\circ} \mathrm{C} \cdot \mathrm{cm} /\right.$ watt), of a mineral such as quartz is 11, water 165, air 4000 and for organic matter approximately twice as much as that of the mineral components. Because the resistivities of most minerals are significantly less than that of water and air, the soll mass should consist of as much solids as possible if low resistivity is desired. Another consideration is the amount of water that can be adsorbed and/or absorbed by the soil since we shall see later the importance of soll moisture on soil thermal resistivity. The amount of adsorbed water is affected by the grain size and mineral content and depends on the geometry of the soil particle surfaces and their physico-chemical character, as well as on temperature.

\subsubsection{Density}

Sinclair et al. [13] explained the importance of density when they stated that "In a dry soil, the solid particles form a system of series-parallel paths with each other and with the air-filled voids between them. The presence of air with its high thermal resistivity greatly increases the overall thermal resistivity of the soil as compared with its soil components because: (1) part of the heat path is necessarily through the high-resistivity air, in parallel with the low-thermal-resistivity solid material instead of being all through the low-thermal-resistivity solid material; and (2) because the air makes for poor contact between the solid particles introducing high-thermal-resistivity air paths in series with the low-thermal-resistivity paths through the solid particles." Thus, by reducing the total void volume and improving the contact between the solid grains through densification of the soll mass a reduction in the thermal resistivity of the material will be achieved. The density of soils may be changed by artificial means such as compaction or disturbance of in situ solls (e.g., during electric cable installation) and by such natural factors as consolidation, shrinkage, or swelling. The least resistivity is achieved in the case of the greatest amount of solid material per unit volume. At porosities greater than 50 percent to 65 percent, the normal silt-clay soils in a 
dry state have a thermal behavior determined by the addition of the resistivities of the component phases while below porosities of 50 percent to 65 percent the thermal behavior is determined from the addition of the thermal conductivities of the component phases [14]. The transition occurs at lower porosities for well-graded crushed quartz systems and for sands used as backfill around underground cables (thermal sands). The larger the range of particle sizes, the smaller is the porosity at which this transition occurs. This transition occurs at a porosity when a contacting granular skeleton is formed by the grains of the better conducting quartz sands.

Another factor which should be considered when attempting to improve the thermal stability of a soil is its permeability which determines the potential moisture movement under thermal gradients. This movement of moisture could be critical if moisture restoration is curtailed thereby causing the thermal resistivity to increase. Consequently, an optimum thermal density which is characterized by a high amount of solid material per unit volume and yet a permeability sufficiently great to allow for moisture restoration should be used. Also, the type of fine-grained material present is a factor when attempting to reduce soil thermal resistivity because an expansive clay mineral such as montmorillonite would cause the sand particles to be forced apart during compaction by swelling action when moisture is added thereby increasing the thermal resistivity of the soil.

\subsubsection{Moisture Content}

Recalling the difference in the thermal resistivity between air and water, another important factor to consider is the extent to which the voids (or pore spaces) are filled with water. The terms usually used to characterize this soil property are moisture content and degree of saturation. The moisture content is defined as the mass of free water expressed as a percentage of dry mass of a given soil volume while the degree of saturation is defined as the volume of free water expressed as a percentage of the volume of voids.

The importance of soil moisture is illustrated in figures $3-1$ and $3-2$. As moisture is added to the soil as a thin film around the soil particles or wedges at the contacts, a path for the flow of heat which bridges the air gaps between the solid particles is provided. By Increasing the effective contact areas between particles these films or wedges greatly reduce the thermal resistivity of the soil.

When the moisture condition in the soil approaches the wet condition shown in figure 3-1, the effective contact area no longer increases with increasing moisture content. Consequently, the significant decrease in thermal resistivity is not evident when additional moisture is added to fill the pore space.

The moisture content at which the bridge mechanism breaks down (with a resulting disproportionate increase in the thermal resistivity with a small reduction in moisture content) has been referred to as the "critical moisture content" by Radhakrishna et al. [16]. This critical moisture content depends on the particle size distribution, particle shape and density. These trends are shown in figure 3-2. 
Moisture migration is also an important consideration. Thermal gradients existing in the soll cause a redistribution of moisture in the soil thereby changing the thermal resistivity of the soll. Because moisture migration under a thermal gradient involves capillary moisture, $1 . e$. , moisture in excess of adsorbed (hygroscopic) water that is held against the force of gravity [17], the existing moisture content in the soil is an important consideration in deciding whether moisture migration is a problem. The rate of moisture migration under thermal gradients is zero outside the limits of the capillary moisture range. In the field of agronomy, the limits of the capillary moisture range are defined by the hygroscopic coefficient and the field capacity. The hygroscopic coefficient is the boundary between moist-appearing and dryappearing soil. The field capacity represents the maximum amount of water that can be held against the force of gravity. The maximum migration rate occurs at an intermediate moisture level between the hygroscopic coefficient and the field capacity, near the wilting coefficient. The wilting coefficient is defined as the soil-moisture condition at which the ease of release of water to the plant roots is just barely too small to counter-balance the transpiration losses. The previously discussed limits are determined by measurements of soil moisture tension as given by Kohnke [18]. The soil moisture scale which provides the approximate relationship of soil moisture terms that have been referred to is presented in figure 3-3. Figure 1-1 also provides a qualitative comparison of the differences in terminology used by agronomists and geotechnical engineers, and it shows that the plastic limit of fine-grained soils is in the vicinity of the upper limit of the capillary moisture range. Hence, the plastic limit seems to coincide with the negative pressure (tension or suction) of the soil moisture at which considerable moisture migration occurs upon application of a thermal gradient [19]. Furthermore, Salomone [4] has presented data that suggest that the plastic limit defined by geotechnical engineers can be correlated with the critical moisture content. Results from this study, as discussed in section 4 provide additional insight into the relationship among the critical moisture content, optimum moisture content and the plastic limit of fine-grained soils.

In summary, we see that the primary factors affecting the thermal resistivity of soils are: soil composition, density, and molsture content. Empirical correlations between these factors and thermal resistivity are available (e.g., fig. 3-2). However, the key to improving our predictive capability in the field of thermal soil mechanics is a thorough understanding of the soil characteristics which affect thermal soil behavior. A discussion of these characteristics follows.

\subsection{ASSESSING THE ENGINEERING PROPERTIES OF SOILS}

Soil texture, plasticity and cohesiveness form the basis for the soil classification schemes commonly used by geotechnical engineers. Texturally, soils are classified as either coarse-grained (sands and gravels) or finegrained (silts and clays) with the dividing line being whether the soil is retained on/or passes through the $75 \mu \mathrm{m}$ (no. 200) sieve. The particle size distribution of sands and gravels have an important influence on their engineering behavior. For fine-grained soils the engineering properties are greatly affected by the presence of water rather than by the texture alone. 
The presence of water affects the plasticity and cohesiveness of fine-grained soils by affecting the interaction between the mineral grains. The plasticity and cohesion of a soil are indicators of soll type. Clays are both plastic and cohesive while sands are non-plastic and noncohesive (cohesionless). Silts are intermediate between sands and clays. Silts are fine-grained yet non-plastic and cohesionless. These relationships have been summarized by Holtz and Kovacs [3] ( table 3-1).

Table 3-1. Textural and Other Characteristics of Soils (from [3])

\begin{tabular}{|c|c|c|c|}
\hline Soil name: & Gravel, Sands & Silts & Clays \\
\hline Grain size: & $\begin{array}{l}\text { Coarse grained } \\
\text { Can see individual } \\
\text { grains by eye }\end{array}$ & $\begin{array}{l}\text { Fine grained } \\
\text { Cannot see } \\
\text { individual } \\
\text { grains }\end{array}$ & $\begin{array}{l}\text { Fine grained } \\
\text { Cannot see } \\
\text { individual } \\
\text { grains }\end{array}$ \\
\hline \multirow[t]{2}{*}{ Characteristics: } & Cohesionless & Cohesionless & Cohesive \\
\hline & $\begin{array}{l}\text { Nonplastic } \\
\text { Granular }\end{array}$ & $\begin{array}{l}\text { Nonplastic } \\
\text { Granular }\end{array}$ & $\begin{array}{c}\text { Plastic } \\
-\end{array}$ \\
\hline $\begin{array}{l}\text { Effect of water } \\
\text { on engineering } \\
\text { behavior: }\end{array}$ & $\begin{array}{l}\text { Relatively unimportant } \\
\text { (exception: loose sat- } \\
\text { urated granular materi- } \\
\text { als and dynamic } \\
\text { loadings) }\end{array}$ & Important & Very important \\
\hline $\begin{array}{l}\text { Effect of grain } \\
\text { size distribution } \\
\text { on engineering } \\
\text { behavior: }\end{array}$ & Important & $\begin{array}{l}\text { Relatively } \\
\text { unimportant }\end{array}$ & $\begin{array}{l}\text { Relatively } \\
\text { unimportant }\end{array}$ \\
\hline
\end{tabular}

By mechanical analysis the particle size distribution (texture) of a soll is obtained. Detailed procedures for this test have been specified by ASTM D 422-72 (Standard Method for Particle-Size Analysis of Soils) procedures [12]. Atterberg Limit tests $[12,20,21]$ are used to measure the plasticity of finegrained soils. The Atterberg Limits are moisture contents which represent important limit states of engineering behavior (fig. 3-4). By knowing the natural moisture content of a soil in relation to its Atterberg Limits, the engineering response of a soil can be predicted. Because Atterberg Limits are limiting moisture contents, these limits of engineering behavior can be shown on a moisture content continuum (fig. 3-5).

From figure 3-5 we see how geotechnical engineers use the results of classification tests to show: a) types of soil behavior for given ranges of moisture contents, and b) changes in the state of soil as moisture content changes. This figure serves to demonstrate the need to establish classification 
tests which indicate the thermal behavior of soils. Results from this study discussed in section 4 begin to meet this need for fine-grained soils.

\subsection{DETERMINING THE THERMAL BEHAVIOR OF SOILS}

\section{$3.4 .1 \cdot$ General}

Progress in the determination of the thermal behavior of soils has been hampered by the fact that information on thermal soil properties that is scattered in a variety of technical fields has not been consolidated, and professionals lack a common language to describe the thermal behavior of soils.

Procedures used to evaluate the thermal properties of soils are based on routine methods adopted over the years but do not necessarily reflect all the information and techniques now available in the various disciplines faced with the problem of soll characterization and the prediction of heat transfer in soils. As part of these routine procedures, heat flow problems are frequently solved using constant values of soil thermal conductivity from "handbooks" without considering the factors which affect soil thermal conductivity previously discussed. Also, researchers have not always documented their findings in terminology that is consistent nor correlated their results with the findings of earlier work [2].

Use of soil as an insulating material or a material to dissipate heat requires that progress be made in this area and a systematic approach be developed.

\subsubsection{Approach}

After reviewing the factors that influence the thermal resistivity of soil and the methods available to assess the type and properties of soils, the hypothesis is advanced that thermal soil behavior can be correlated with the soil limit states associated with moisture content, which in turn can be identified by methods developed by geotechnical engineers and agronomists. The program reported herein was designed to test this hypothesis for one cohesive soil and examine existing data for other fine-grained soils to determine whether the findings of the tests also apply to other materials.

The following approach was used:

1. Select one fine-grained soil whose index properties are well known. Hence, AMRL Reference Soil No. 61 described in section 2.2 was selected.

2. Investigate in detail the influence of moisture and density on the thermal resistivity of the AMRL reference soil and correlate the trends with the limit states of soil behavior (Atterberg Limits) and other index properties used by geotechnical engineers.

3. Identify the concepts, methods and tests which aid in the determination of the thermal behavior of the AMRL reference soil using the results from step 2, above. 
4. Obtain index property and thermal resistivity test data for other fine-grained soils. Apply the concepts, methods, and tests identified for for the AMRL reference soil to these solls and establish whether they are also appropriate for these solls. 


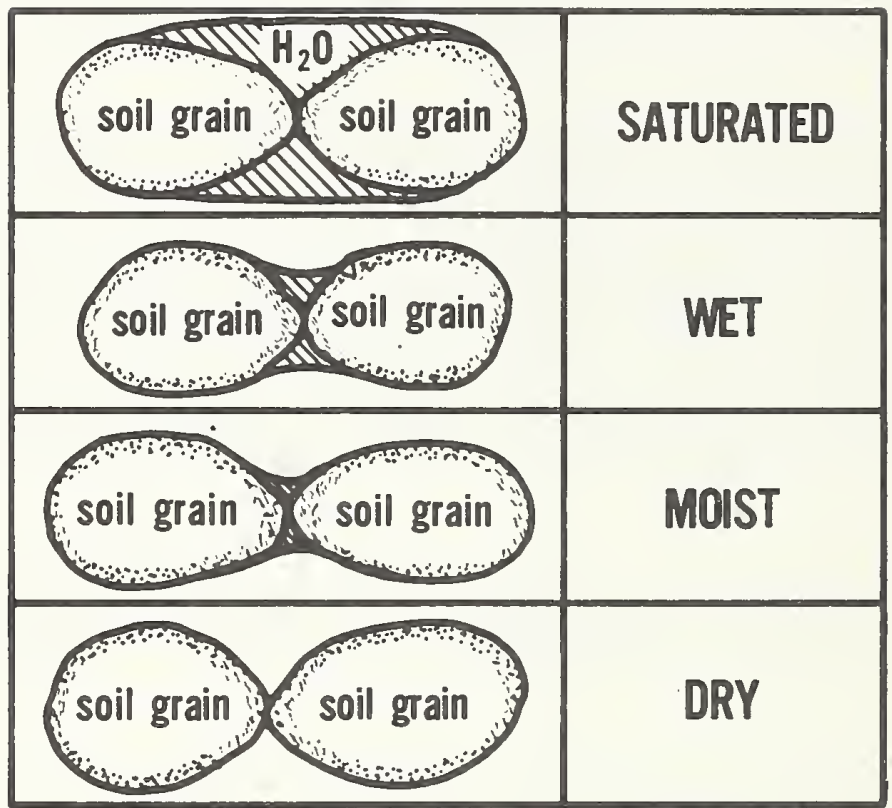

Figure 3-1. The effect of soll moisture on the heat flow path (from [4]) 


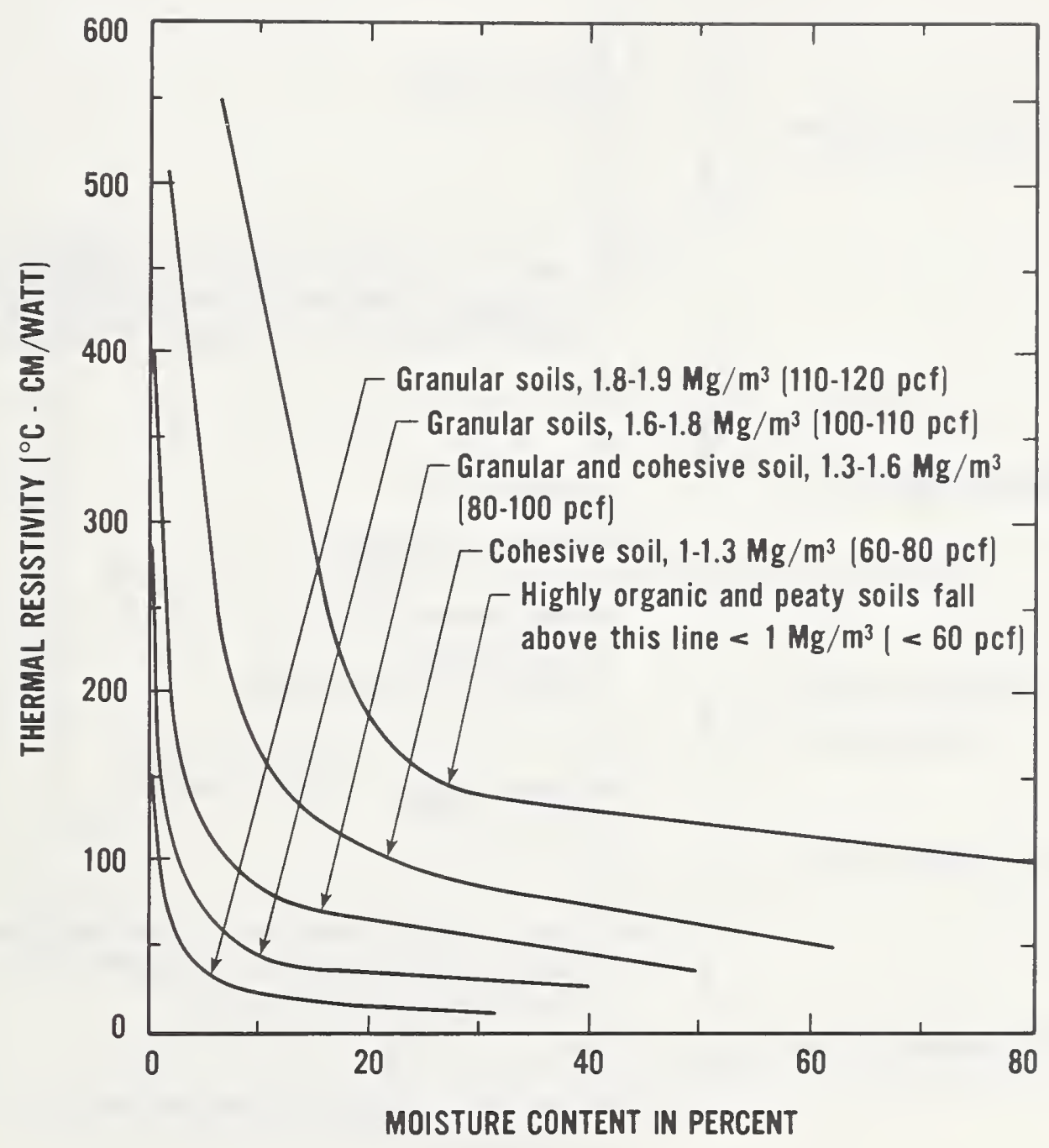

Figure 3-2. The effect of moisture content and dry density on the thermal resistivity of soils (from [15]) 


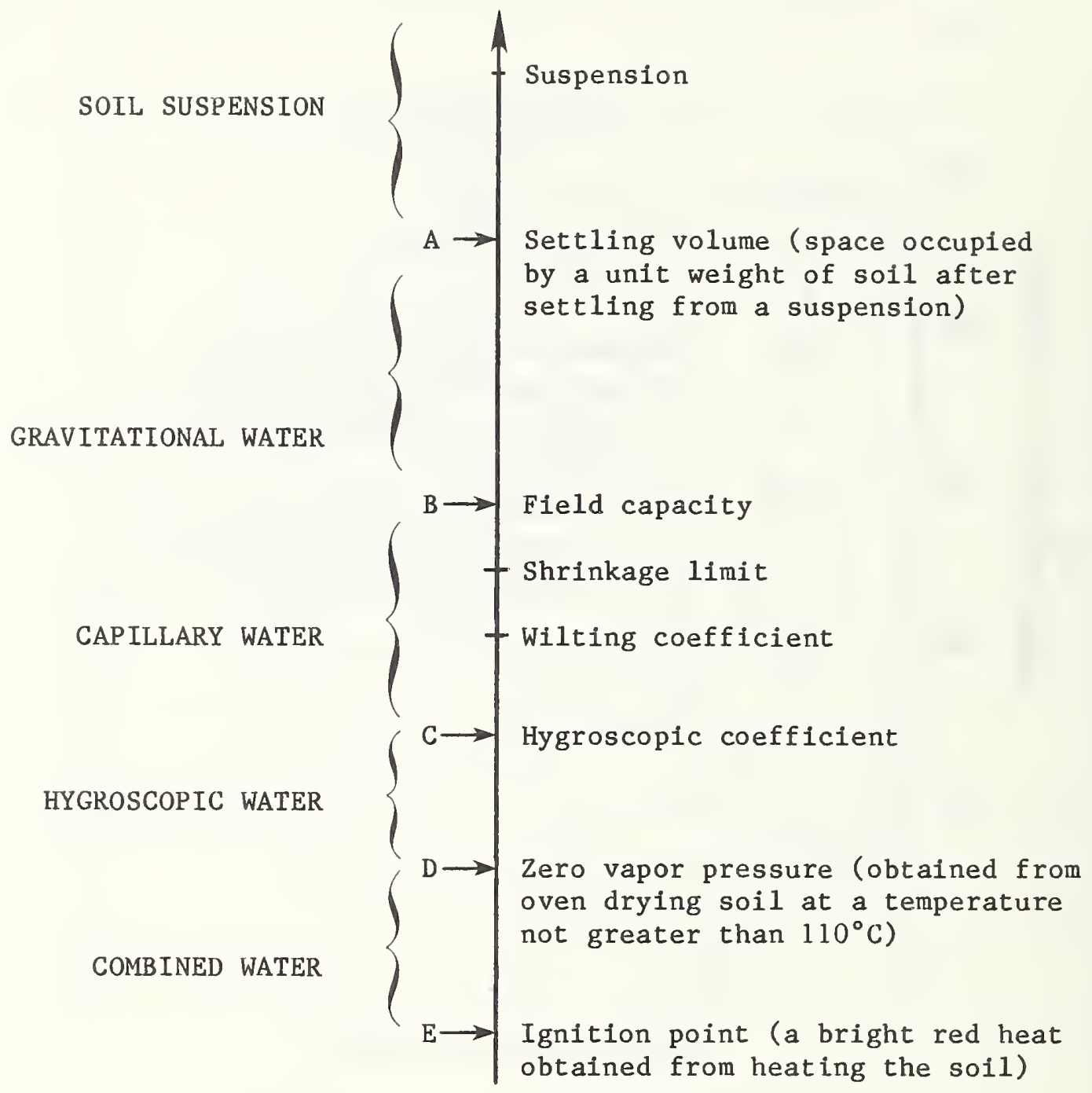

Figure 3-3. Soll moisture scale showing soil moisture terms used by agronomists (modified from [17]) 


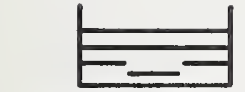

FLUID SOIL-WATER MIXTURE

\section{LIQUID}

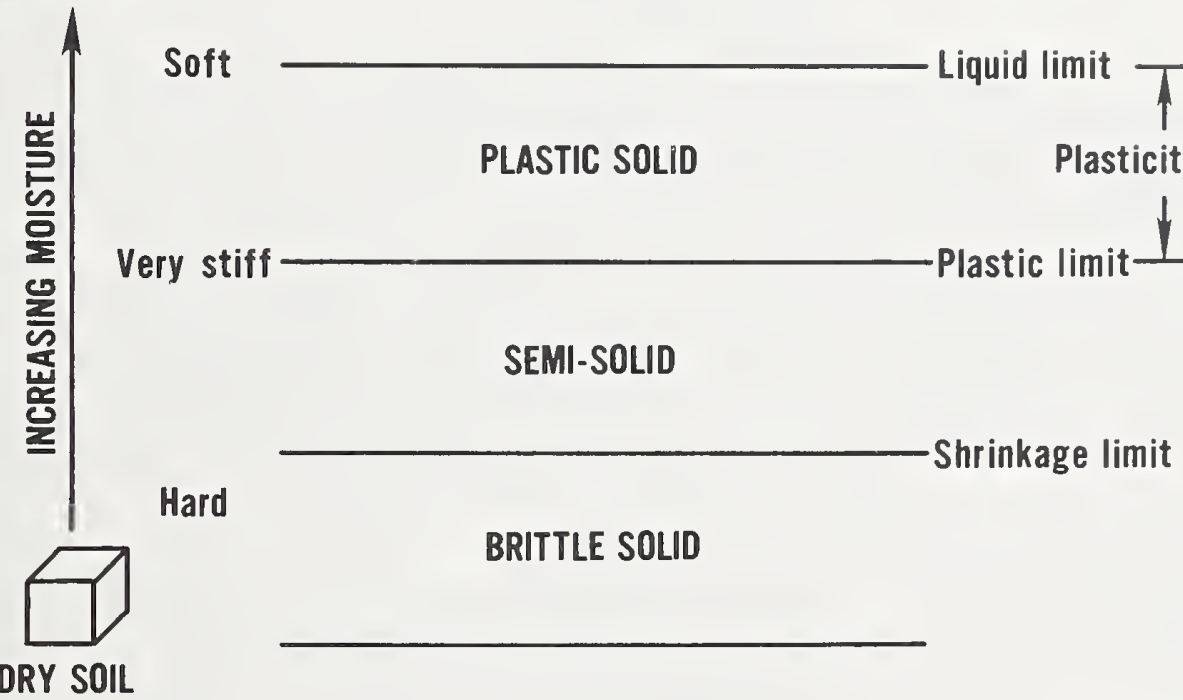

Figure 3-4. Soil moisture scale showing soll moisture terms (Atterberg Limits) used by geotechnical engineers for fine-grained soils (from [4]) 
FACING PAGE: The Laboratory Equipment Used to Determine the Thermal Properties of Soils.

Shown are the thermal property analyzer with printout device, and two soil samples with laboratory thermal probes inserted.



Figure 3-5. Moisture content continuum showing the various states of fine-grained solls and the generalized stress-strain response (modified from [3]) 


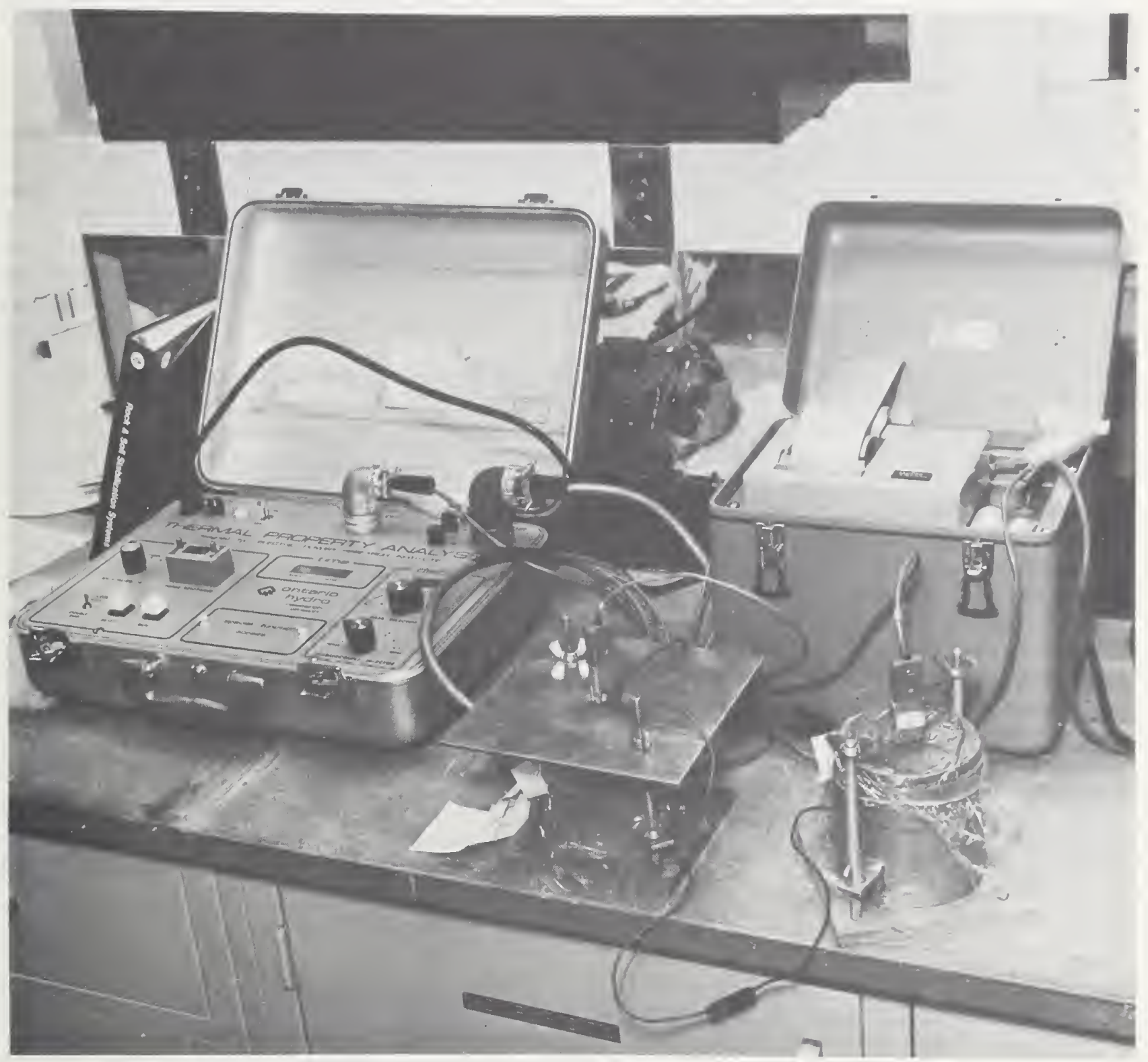

\section{PRESENTATION AND DISCUSSION OF TEST RESULTS}

\subsection{GENERAL}

The tables and figures in this section provide information on: a) the influence of density and moisture content on the thermal resistivity of the AMRL reference soil, b) the correlation of the trends observed in part a above with the compaction characteristics and the Atterberg Limits of the soil used in the study, and $c$ ) the index property and thermal resistivity test data for other fine-grained soils. A discussion of the data tabulated according to compactive effort in tables A-1 through A-8 in appendix A follows. It should be pointed out that, in most instances, no significant differences in measured values of thermal resistivity were observed for specimens compacted to the 
same moisture content and density. However, when comparing thermal resistivity test data from specimens remolded using S6 and $\$ 4$ compactive efforts (see section 2.3.4) with thermal resistivity test data from specimens remolded using S12 compactive effort or greater, additional scatter in measured thermal resistivity were observed for specimens with the same moisture content and dry density. These differences could be caused by differences in soil fabric of the specimens tested. Voids were observed on the outer surface of the specimens compacted using the S6 and S4 compactive efforts. Therefore, the data for compactive efforts of $\mathrm{S} 6$ and 54 were not used in constructing figures 4-1

through 4-6.

\subsection{EFFECT OF DENSITY}

The influence of density on the thermal resistivity of the AMRL reference soil can be seen in figures 4-1 through 4-4. Figure 4-1 shows the variation of thermal resistivity with changes in moisture content for constant values of density. By reducing the total void volume and improving the contact between the solid grains through densification of the soll mass, a reduction in the thermal resistivity of the material can be achieved. We also see that the minimum thermal resistivity for a given density occurs as the zero air voids curve (100 percent saturation) is approached. Examination of the data for the modified and standard energies in appendix A provides additional insight into the thermal behavior of this material. The minimum and maximum thermal resistivity under saturated conditions can be approximated by measuring the thermal resistivity of two samples. One sample should be tested at the optimum moisture content* and maximum dry density* determined using the modified energy and the other sample should be tested at the liquid limit and that density which results from using standard energy. A thermal performance index can then be defined by the slope of the dashed line in figure 4-1. Eq. 8 approximates the slope of this line as follows:

$$
T P I=\frac{\rho_{3}-\rho_{M}}{L L-w_{o p t}}
$$

where

$\mathrm{TPI}=$ thermal performance index

$\rho_{S}=$ thermal resistivity of a sample prepared using standard energy (ASTM D 698-78 procedures, [12]) and a moisture content equal to the liquid limit, ${ }^{\circ} \mathrm{C} \cdot \mathrm{cm} / \mathrm{W}$

$\rho_{\mathrm{M}} \quad=$ thermal resistivity of a sample prepared using modified energy (ASTM D 1557-78 procedures, [12]) and a moisture content equal to the modified optimum moisture content, ${ }^{\circ} \mathrm{C} \cdot \mathrm{cm} / \mathrm{W}$

LL = liquid limit as defined by ASTM D 423-72 procedures, [12], percent

$\mathrm{w}_{\text {opt }}=$ optimum moisture content using modified energy (ASTM D 1557-78 procedures, [12]), percent.

* The terms optimum moisture content and maximum dry density are explained in section 4.4 . 
For the AMRL reference soil, the thermal performance index is:

$\frac{75-48}{45-14}=0.87 \approx 1$. The Thermal Performance Index, TPI, provides an indication of the thermal performance of the ARML reference soll under saturated conditions. It measures the change in thermal resistivity per unit change in moisture content over the range of densities expected under natural or artificial (man-made) field conditions. By taking into account the compaction characteristics and the thermal behavior of the soil, it is expected that this index may help in comparing quantitatively the thermal behavior of other fine-grained soils. Figure 4-2 presents the effect of density on the thermal conductivity of the AMRL reference soll for the purpose of comparison with Kersten data [22]. By keeping the moisture content constant and examining the change in thermal conductivity with density, the relationships in figure 4-2 and table 4-1 are obtained.

Table 4-1. Thermal Conductivity-Density Relationships

\begin{tabular}{|c|l|}
\hline $\begin{array}{c}\text { MOISTURE CONTENT } \\
\text { IN PERCENT }\end{array}$ & \multicolumn{1}{|c|}{$\begin{array}{c}\text { EQUATION OF CURVE FOR } \\
\text { CONDUCTIVITY IN } \\
\text { WATT } /{ }^{\circ} \mathrm{C} \cdot \mathrm{Cm}^{*}\end{array}$} \\
\hline 9.5 & $\mathrm{k}=0.00007144(10) 1.304 \rho \mathrm{d}$ \\
13.0 & $\mathrm{k}=0.001448(10) 0.597 \rho_{\mathrm{d}}$ \\
17.0 & $\mathrm{k}=0.002803(10) 0.472 \rho \mathrm{d}$ \\
22.5 & $\mathrm{k}=0.01802$ \\
27.0 & $\mathrm{k}=0.01657$ \\
\hline
\end{tabular}

In general, in accordance with Kersten [22], the thermal conductivity varied with density according to the following equation:

where

$$
\mathrm{k}=\mathrm{A} 10^{\mathrm{B} \cdot \rho_{\mathrm{d}}}
$$

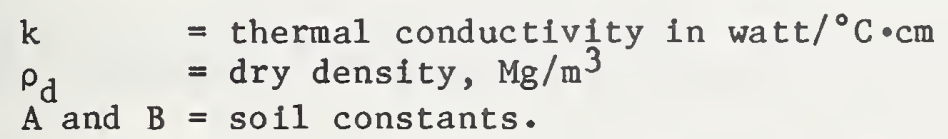

The results in figure 4-2 are in general agreement with the trends observed by Kersten [22]. However, in contrast to the Kersten [22] data, it was found that at moisture contents greater than 22.5 percent, the thermal conductivity was not significantly affected by density. Because the change in the Kersten [22] trend occurred at a moisture content close to the plastic limit ( 23.5 percent), the significance and validity of this finding should be confirmed with thermal probe tests on other fine-grained soils. This trend is also observed when the thermal resistivity versus dry density for constant moisture contents is plotted as shown on figures 4-3 and 4-4. The influence of density on the thermal resistivity continues to decrease until a moisture content in the vicinity of the plastic limit is reached. At molsture contents close to the plastic limit the effect of density is minimal. 


\subsection{EFFECT OF MOISTURE CONTENT}

The influence of moisture content on the thermal resistivity of the AMRL reference soil is shown in figures $4-1$ and $4-5$ and table 4-2. Figure 4-1 shows that for a given density the thermal resistivity decreases with increasing moisture content until the critical moisture content (knee of the curve) is reached or, as in the case for the high densities (e.g. $1.84 \mathrm{Mg} / \mathrm{m}^{3}$ ), until the zero air voids curve is approached. The trend in figure 4-1 suggests that if we want to explore the relationship between thermal resistivity and moisture content over a wide range of moisture contents for the purpose of correlating the observed trend with the limit states of soil behavior (Atterberg Limits), low density samples should be used. Also, a compactive effort which results in relatively constant density values over a wide range of moisture contents would be desirable to eliminate the influence of density on the test results.

Figure 4-5 is a plot of the thermal conductivity versus the logarithm of the moisture content. Such a plot ordinarily gives a straight line for that part of the data above a certain minimum moisture content. Kersten's [22] data suggests that this minimum moisture content is 7 percent for silt or clay soils. Considering this fact, straight lines for constant values of density were drawn on figure 4-5. This type of plot appears to fit the data as it did the Kersten's [22] data, and equations have been developed for the relationships shown in figure 4-5 (see table 4.2).

Table 4-2. Thermal Conductivity-Moisture Content Relationships

\begin{tabular}{|c|c|c|}
\hline $\begin{array}{l}\text { DRY DENSITY } \\
\left(\mathrm{Mg} / \mathrm{m}^{3}\right)\end{array}$ & \begin{tabular}{|c|} 
MOISTURE CONTENT \\
RANGE IN WHICH APPLICABLE \\
(PERCENT)
\end{tabular} & $\begin{array}{l}\text { EQUATION FOR CONDUCTIVITY } \\
\text { IN Watt } /{ }^{\circ} \mathrm{C} \cdot \mathrm{cm}^{*}\end{array}$ \\
\hline $\begin{array}{l}1.84 \\
1.72 \\
1.66 \\
1.54\end{array}$ & $\begin{array}{r}12 \text { to } 17 \\
9 \text { to } 21 \\
14 \text { to } 23 \\
14 \text { to } 27\end{array}$ & $\begin{array}{l}\mathrm{k}=0.0215 \log \mathrm{w}-0.00506 \\
\mathrm{k}=0.0186 \log \mathrm{w}-0.00576 \\
\mathrm{k}=0.0169 \log \mathrm{w}-0.00487 \\
\mathrm{k}=0.0146 \log \mathrm{w}-0.00441\end{array}$ \\
\hline & & * For $\mathrm{k}$ in $\mathrm{W} / \mathrm{m} \cdot{ }^{\circ} \mathrm{K}$ multiply by 100 \\
\hline
\end{tabular}

The equations are of the Kersten [22] form:

$$
\mathrm{k}=\mathrm{A}_{1} \log (W)+\mathrm{B}_{1}
$$

where

$$
\begin{aligned}
& \mathrm{k}=\text { thermal conductivity, } \mathrm{W} /{ }^{\circ} \mathrm{C} \cdot \mathrm{cm} \\
& \mathrm{A}_{1}=\text { the slope of the } 1 \text { ine, } \\
& \mathrm{B}_{1}=\text { the value of the intercept of the curve at } 1 \text { percent moisture, and } \\
& W^{\prime}=\text { moisture content, expressed as a percent. }
\end{aligned}
$$


These equations allow determination of the molsture content of the AMRL soll if the thermal conductivity is measured and the approximate density is known for the purposes of selecting the appropriate equation. Once again it should be pointed out that the moisture content referred to in the preceding discussion is the inner moisture content of the center core soil sample as defined in section 2.3.6. A comparison of the inner, outer, and total molsture content and the moisture content of the trimmings is provided in tables A-9 through A-15 in appendix A. There was no significant difference observed among the inner, outer and total moisture contents. This observation is consistent with the trend expected for fine-grained, laboratory cured soil samples. Any difference between the moisture content of the trimings with the other moisture contents determined results from the rapid rate of drying observed for the trimmings while the thermal probe test sample was being trimmed. Therefore, a lower initial weight was measured for the trimmings.

The moisture losses (or gains) of the thermal probe test samples during the thermal probe test are shown on tables A-16 through A-22. The average moisture loss was -0.04 percent. Seven samples gained moisture during the thermal probe test. The average moisture gain was 0.01 percent.

\subsection{DETERMINATION OF SOIL THERMAL BEHAVIOR}

After determining the influence of density and moisture content on the thermal resistivity of the AMRL reference soil, an attempt can be made to define an approach which will aid in determining the thermal behavior of fine-grained soils. Figure 4-6 constructed using the same data as figures 4-2 and 4-5 serves as an aid in estimating the thermal conductivity of the AMRL reference soil using the moisture content and dry density of the soil. It is also interesting to note that figure 4-6 can be used with the equations in tables $4-1$ and 4-2 to estimate the moisture content and dry density of the AMRL reference soil if the thermal conductivity is known. This concept is important because as data on other fine-grained soils become available using the form of data presentation shown, engineers may be able to use the thermal conductivity of the soil to estimate its moisture content and dry density.

The next step in determining the thermal behavior of the AMRL reference soil is to correlate its trends in thermal resistivity versus moisture content and dry density, with its compaction characteristics and Atterberg Limits. When the dry densities of each sample are determined and plotted versus the moisture contents for each sample and compactive effort, curves called compaction curves are obtained (figure 4-7). Each data point on the curves shown represents a single compaction test for which the thermal resistivity was determined. Each curve is unique for the AMRL reference soil and the method of impact compaction and compactive effort used in the program. The peak point corresponding to the maximum dry density is an important point. It is known as the optimum moisture content. Note that the maximum dry density is only a maximum for a specific compactive effort. Increasing the compactive effort increases the maximum dry density, as expected, but also decreases the optimum moisture content. The compaction curves flatten out with a decrease in compactive effort. Note too that the compaction curves, even at higher moisture contents and compactive efforts, never actually reach the curve for "100 percent saturation" (traditionally 
called the zero air voids curve). Test specimens were prepared by 7 different compaction energies as described in section 2.3 .4 to obtain the thermal resisitivity/conductivity data over a wide range of density and moisture.

The modified energy (ASTM D 1557-78 [Standard Test Methods for Moisture Density Relations of Soils and Soil - Aggregate Mixtures Using 10-1b (4.54-kg) Rammer and 18-in (454-mm) Drop] procedures, [12]) and the standard energy (ASTM D 698-78 [Standard Test Methods for Moisture - Density Relations of Soils and Soil - Aggregate Mixtures Using 5.5-1b (2.49-kg) Rammer and 12-in (305-mm) Drop] procedures, [12]) are commonly used by engineers to determine the moisture-density relation of fine-grained soils. Hence, these energies were selected from the compactive efforts used to mold samples for presentation in figure 4-7. The S6 energy was selected for presentation because it met the criteria stated in section 4.3 , $1 . e .$, it causes a relatively small fluctuation of density over a range of moisture contents from 10 percent to 30 percent. As we will see later, this characteristic will be helpful in correlating the thermal resistivity versus moisture content relationship of this soil with its Atterberg Limits.

The thermal resistivity of test specimens compacted at the dry density and moisture content shown on the compaction curve are shown on figures 4-8 through 4-14 for each of the compactive efforts used in this study. The minimum thermal resistivity for each compactive effort generally occurs at the point of optimum moisture content and maximum density. When a plot of minimum thermal resistivity versus compactive effort is made, the importance of compactive effort (or density) in achieving the minimum thermal resistivity during placement of this material is seen (figure 4-15).

The correlation of the thermal resistivity versus moisture content relationship of the AMRL reference soil with its Atterberg Limits is shown on figure 4-16. When the S6 energy is used to mold the test specimens, the thermal resistivity increases very rapidly with a slight reduction in moisture content below the plastic limit of the soil. Thus, the "critical moisture content" at a low density ( 1.4 to $1.5 \mathrm{Mg} / \mathrm{m}^{3}$ ) can be found using the plastic limit of the soil under investigation. For those involved in soil heat transfer problems, this finding is important. Recalling from figure $1-1$ and section 3.2.3 that the plastic limit generally defines the upper boundary of capillary moisture and that moisture migration under a thermal gradient involves capillary moisture, the negative pressure potential (often termed capillary potential, and more recently matric potential) of soil water defined by the plastic limit can be used to determine the thermal performance and stability of a fine-grained soil. If the measured negative pressure potential of soil water exceeds the negative pressure potential defined by the plastic limit [23], the soil would be expected to be thermally unstable and moisture migration under thermal gradients would be likely.

Because geotechnical engineers do not often measure the matric potential of soil water which results from the capillary and adsorptive forces due to the soil matrix, figure 4-17 presents an approximate approach for evaluating the thermal performance and stability of the AMRL reference soil using the moisture 
content of the soil. Four distinct regions shown on figure 4-17 establish the thermal performance of this soil. The regions are defined by the molsture contents shown in table 4-3. Also, the trend in therial resistivity with increasing moisture content for each of the regions is described.

Figure 4-17 can also be used to define an index which is a measure of the thermal stabllity of the AMRL reference soll at a dry density of 1.4 to $1.5 \mathrm{Mg} / \mathrm{m}^{3}$ and at a particular moisture content. This moisture content should be the minimum moisture content of the soll that is expected under design conditions. Note that thermal instability occurs in a molst soil as a result of signiflcant moisture movement when the soil is subjected to therral gradients and the moisture content of the soil falls below the critical molsture content. Therefore a large increase in the thermal resistivity occurs.

The index is called by the authors the thermal stabllity index and is defined as follows:

$$
T S I=\frac{w_{D}-P L}{w_{S C}-P L}
$$

where:

$$
\begin{aligned}
\text { TSI = } & \text { Thermal Stability Index } \\
W_{D}= & \text { minimum moisture content expected under design conditions, percent } \\
P L= & \text { Plastic Limit as defined by ASTM D } 424-71 \text { procedures [12], percent } \\
{ }^{W_{S C}=} & \text { supercritical moisture content: } 1 . e \cdot \text {, the moisture content at } \\
& \text { which the thermal resistivity increases with increasing moisture } \\
& \text { content, percent. }
\end{aligned}
$$

\begin{tabular}{|c|c|c|}
\hline $\begin{array}{l}\text { REGION OF } \\
\text { THERMAL } \\
\text { PERFORMANCE } \\
\end{array}$ & $\begin{array}{c}\text { DESCRIPTION OF TREND } \\
\text { IN } \\
\text { THERMAL RESISTIVITY }\end{array}$ & $\begin{array}{l}\text { BOUNDARY } \\
\text { MOISTIRE } \\
\text { CONSTANT }\end{array}$ \\
\hline 1 & $\begin{array}{l}\text { Rapid decrease with increasing } \\
\text { moisture content }\end{array}$ & $\begin{array}{l}\text { PT. A - Oven dry } \\
\text { PT. B - Shrinkage linit }\end{array}$ \\
\hline 2 & $\begin{array}{l}\text { Moderate decrease with } \\
\text { increasing moisture content }\end{array}$ & $\begin{array}{l}\text { PT. B - Shrinkage limit } \\
\text { PT. C - Plastic limit }\end{array}$ \\
\hline 3 & $\begin{array}{l}\text { No change with increasing } \\
\text { moisture content }\end{array}$ & $\left\{\begin{aligned} \text { PT. C - Plastic limit } \\
\text { PT. D - Supercritical } \\
\text { moisture content }\end{aligned}\right.$ \\
\hline 4 & $\begin{array}{l}\text { Moderate increase with } \\
\text { increasing molsture content }\end{array}$ & $\begin{array}{l}\text { PT. D - Supercritical } \\
\text { molsture content } \\
\text { PT. E - Liquid limit }\end{array}$ \\
\hline
\end{tabular}

Table 4-3. Thermal Performance Regions of AMRL Reference Soil (See Fig. 4-17) 
Using the Thermal Stability Index, the thermal stability of this fine-grained soil can be evaluated according to table 4-4. If the supercritical moisture constant was not known, the Liquid Limit of the soil could have been substituted for the supercritical moisture content in equation 11.

Table 4-4. Thermal Stability Index for AMRL Reference Soil

\begin{tabular}{|c|c|}
\hline $\begin{array}{l}\text { THERMAL STABILITY } \\
\text { INDEX (TSI) }\end{array}$ & $\begin{array}{l}\text { DESCRIPTION OF THERMAL } \\
\text { STABILITY }\end{array}$ \\
\hline $\mathrm{TSI} \leq 0$ & $\begin{array}{l}\text { - Unstable } \\
\text { - Moisture migration under thermal } \\
\text { gradients likely }\end{array}$ \\
\hline $0<\mathrm{TSI} \leq 1$ & $\begin{array}{l}\text { - Stable } \\
\text { - Moisture migration under thermal } \\
\text { gradients is unlikely } \\
\text { - Thermal resistivity of the soil is } \\
\text { essentially constant }\end{array}$ \\
\hline TSI $>1$ & $\begin{array}{l}\text { - Stable } \\
\text { - Thermal resistivity increases with } \\
\text { increasing moisture content }\end{array}$ \\
\hline
\end{tabular}

\subsection{THERMAL BEHAVIOR OF OTHER FINE-GRAINED SOILS}

The literature was examined to obtain data on soils with known index and thermal properties. This was accomplished after the concepts, methods and tests described in the preceding sections were identified as being useful when predicting the thermal behavior of the AMRL reference soil. Because the available information is quite limited and authors measuring the thermal properties of soils often do not classify the soils tested using a common soil classification system, nor do they provide the index properties and compaction characteristics of the soil they tested, the information presented was obtained through the cooperation of other researchers. Information in the literature generally fell into two groups. Group 1 contained those soils in which stage drying of one sample was performed to determine the thermal resistivity versus moisture content relationship. Group 2 contained those soils in which the thermal resistivities of samples at different moisture contents and densities were measured. The thermal resistivity versus moisture content relationship using data from [22] had to be determined by adjusting each thermal resistivity reported for density. The Kersten equation for fine-grained soils [22] was used to adjust the measured thermal resistivity for density. The Kersten equation is:

Thermal conductivity, $\mathrm{k}=[0.9 \log$ (Moisture Content) -0.2$] 100.01 \mathrm{x}$ Unit Wgt.

A summary of the data found in the literature is provided in tables $4-5$ and 4-6 and figures 4-18 through 4-24. It should be pointed out that because the available data were quite limited, only the concepts of correlating the critical moisture content with the optimum moisture content and plastic limit was evaluated. 
Table 4-5. Correlation of Critical Moisture Content and Optimum Moisture Content for Other Fine-Grained Soils

\begin{tabular}{|c|c|c|c|c|c|c|}
\hline CATEGORY & $\begin{array}{c}\text { SOIL } \\
\text { DESCRIPTION } \\
\end{array}$ & $\begin{array}{c}\text { UNIFIED } \\
\text { SOIL } \\
\text { CLASSIFICATION } \\
\end{array}$ & $\begin{array}{l}\text { CRITICAL } \\
\text { MOISTURE } \\
\text { CONTENT } \\
\text { (PERCENT) } \\
\end{array}$ & $\begin{array}{c}\text { DRY } \\
\text { DENSITY } \\
\text { OF } \\
\text { SAMPLE }\end{array}$ & $\begin{array}{c}\text { OPT IMUM } \\
\text { MOISTURE } \\
\text { CONTENT } \\
\text { (PERCENT) } \\
\end{array}$ & $\begin{array}{c}\text { FIGURE } \\
\text { AND } \\
\text { REFERENCE } \\
\end{array}$ \\
\hline Group 1 & Georgia Clay & ML & 18 & $\begin{array}{l}77 \% \text { of } \\
\text { standard } \\
\text { maximum } \\
\text { density }\end{array}$ & $\begin{array}{c}19 \\
\text { (standard } \\
\text { energy) }\end{array}$ & $\begin{array}{l}\text { 4-18 Black, } \\
1982 \text {, private } \\
\text { communication }\end{array}$ \\
\hline \multirow{7}{*}{ Group 2} & Niagara Clay & CL & 20 & NA & $\begin{array}{c}20 \\
\text { (standard } \\
\text { energy) }\end{array}$ & $4-19,[24]$ \\
\hline & $\begin{array}{l}\text { P4505 Northway } \\
\text { Silt Loam }\end{array}$ & ML & 16 & NA & $\begin{array}{l}16 \\
\text { (modified } \\
\text { energy }\end{array}$ & $4-20,[22]$ \\
\hline & $\begin{array}{l}\text { P4602 Fairbanks } \\
\text { Silt Loam }\end{array}$ & ML & 16 & NA & $\begin{array}{c}16 \\
\text { (modified } \\
\text { energy) }\end{array}$ & $4-21,[22]$ \\
\hline & $\begin{array}{l}\text { P4710 Fairbanks } \\
\text { Silty Clay Loam }\end{array}$ & ML & 18 & NA & $\begin{array}{c}18 \\
\text { (modified } \\
\text { energy) }\end{array}$ & $4-22,[22]$ \\
\hline & P4708 Healy Clay & CL & 17 & NA & $\begin{array}{c}17 \\
\text { (modified } \\
\text { energy) }\end{array}$ & $4-23,[22]$ \\
\hline & $\begin{array}{l}\text { P4713 Ramsey } \\
\text { Sandy Loạm }\end{array}$ & CL & 9 & NA & $\begin{array}{c}9 \\
\text { (modified } \\
\text { energy) }\end{array}$ & $4-24,[22]$ \\
\hline & Little Long Till & $\mathrm{CL}$ & 12 & NA & $\begin{array}{c}12 \\
\text { (standard } \\
\text { energy) }\end{array}$ & [24] \\
\hline
\end{tabular}

The index property and thermal resistivity test data obtained for the other fine-grained soils shown in Table 4-5 indicate that the critical moisture content of fine-grained soils can be defined by the optimum moisture content. To use the optimum moisture content to define the critical moisture content it is important to understand that:

1) a dry density must be specified when defining the critical moisture content of a soil because the critical moisture content increases as density decreases 
(figure 4-1). (The dry density specified can be the in situ dry density (natural) or a dry density which is a percentage of the laboratory maximuin dry density deternined by some standard test, e.g. standard Proctor test (ASTM D698-78 procedires) ur the nodified Proctor test (ASTM D1557-78 procedures).

2) The compactive effort chosen to determine the optimun moisture content will depend on the dry density for which the critical moisture content is being defined.

3) The critical moisture content is the moisture content at which the minimum value of thermal resistivity is observed. The index property and thermal resistivity test data obtained for the other fine-grained soils shown in table 4-6 indicate that the critical moisture content of fine-grained soils can be defined by the plastic limit for marine sediments that have low natural dry densities. Hence, it appears that the critical moisture content correlates with the optimum moisture content for soils over a wide range of densities. However, as the density of the fine-grained soil decreases to densities typical of unconsolidated marine deposits, a correlation between the critical moisture content and the plastic limit is evident.

Table 4-6. Correlation of Critical Moisture Content and Plastic Limit for Other Fine-Grained Soils

\begin{tabular}{l|l|c|c|c|c}
\hline Gategory & Soil Description & $\begin{array}{c}\text { Unified } \\
\text { Soil } \\
\text { Classification }\end{array}$ & $\begin{array}{c}\text { Critical } \\
\text { Moisture } \\
\text { Content } \\
\text { Percent) }\end{array}$ & $\begin{array}{l}\text { Plastic } \\
\text { Limit } \\
\text { (Percent) }\end{array}$ & Reference \\
\hline & $\begin{array}{l}\text { Lake Erie } \\
\text { Bottom Sediments } \\
\text { (very soft clay) }\end{array}$ & $\mathrm{CH}$ & $30-40$ & $35-45$ & [25] \\
\hline $\begin{array}{l}\text { Lake Erie } \\
\text { Bottom Sediments } \\
\text { (soft clay) }\end{array}$ & $\mathrm{CH}$ & $25-30$ & $25-30$ & [25] \\
\hline $\begin{array}{l}\text { Atlantic City } \\
\text { Marine Sediments }\end{array}$ & $\mathrm{CH}$ & 30 & 30 & [4] \\
\hline $\begin{array}{l}\text { Georgia Strait } \\
\text { Bottom Sediments }\end{array}$ & OH & 66 & 68 & [26] \\
\hline $\begin{array}{l}\text { Malaspina Strait } \\
\text { Bottom Sediments }\end{array}$ & OH & 74 & 68 & [26] \\
\hline
\end{tabular}

The limited amount of data in the literature, that are available to corroborate the concepts presented in this report, points to the need for researchers to consider these concepts when planning the laboratory testing programs for determining the thermal properties of soils and when reporting their findings. 


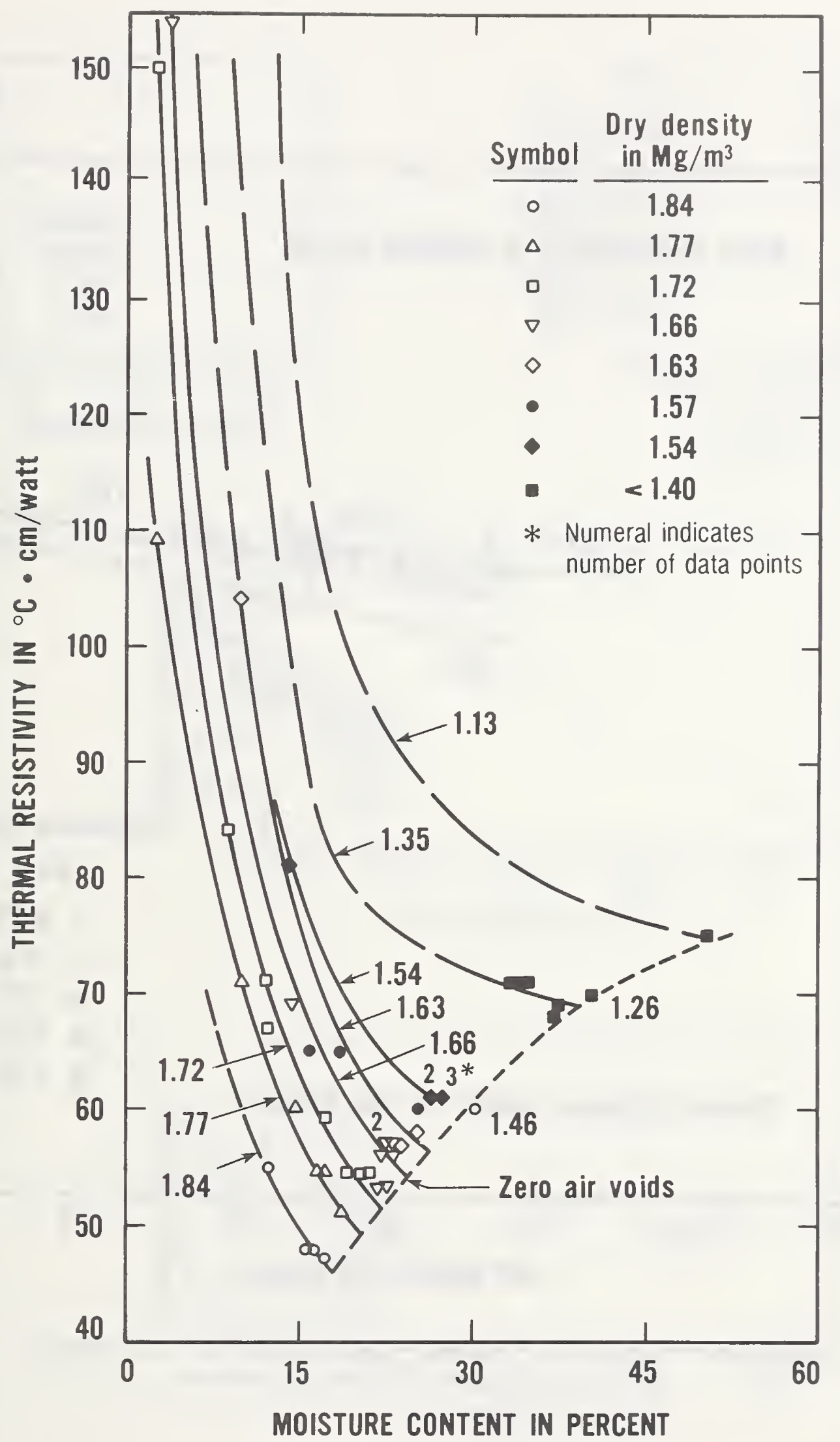

Figure 4-1. Variation of thermal resistivity with moisture content and dry density for AMRL Reference Soil 




Figure 4-2. Variation of thermal conductivity with dry density for various values of moisture content 

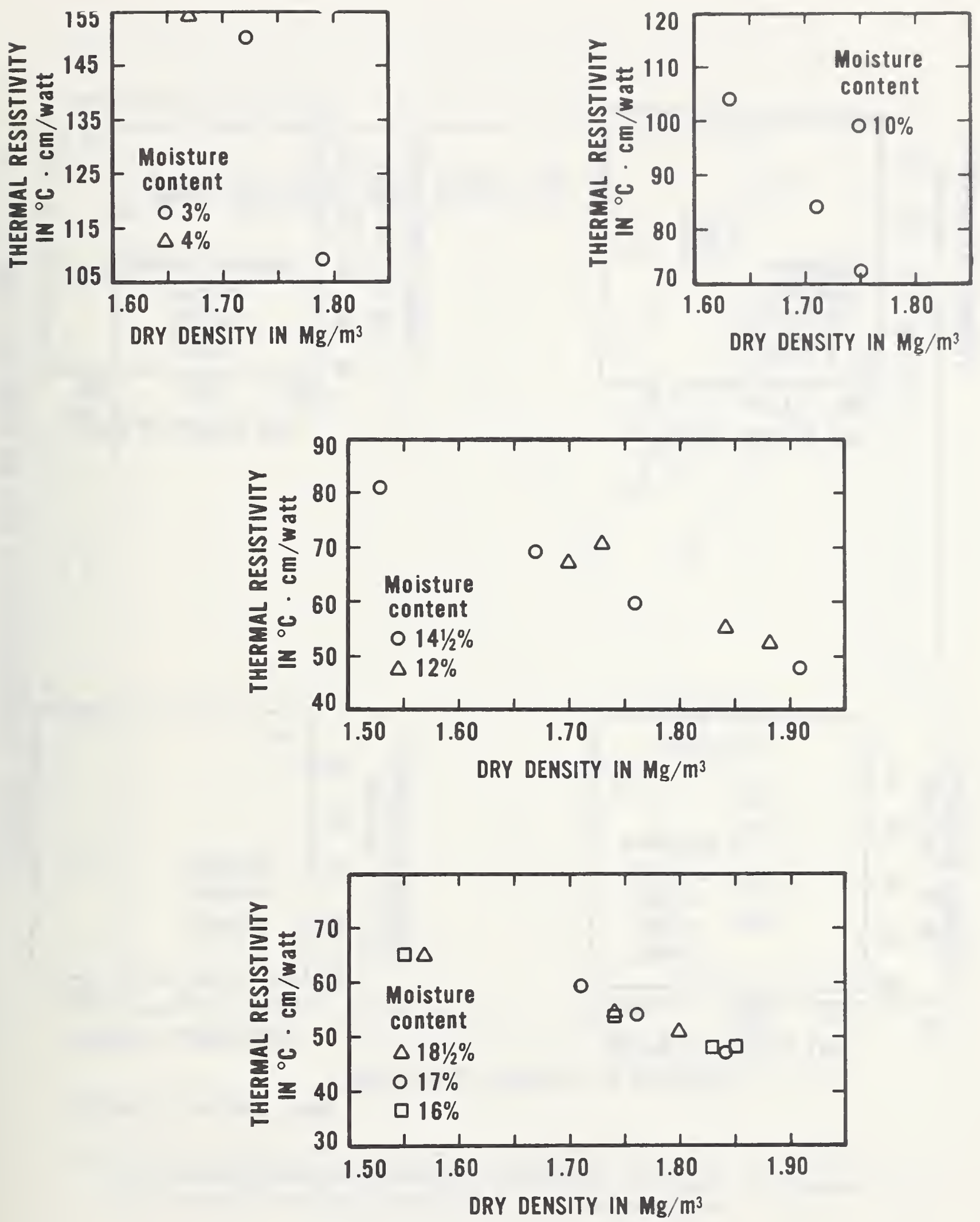

Note: $1 \mathrm{Mg} / \mathrm{m}^{3}=62.4 \mathrm{PCF}$

Figure 4-3. Variation of thermal resistivity with dry density for moisture contents of 3 percent to $18-1 / 2$ percent 

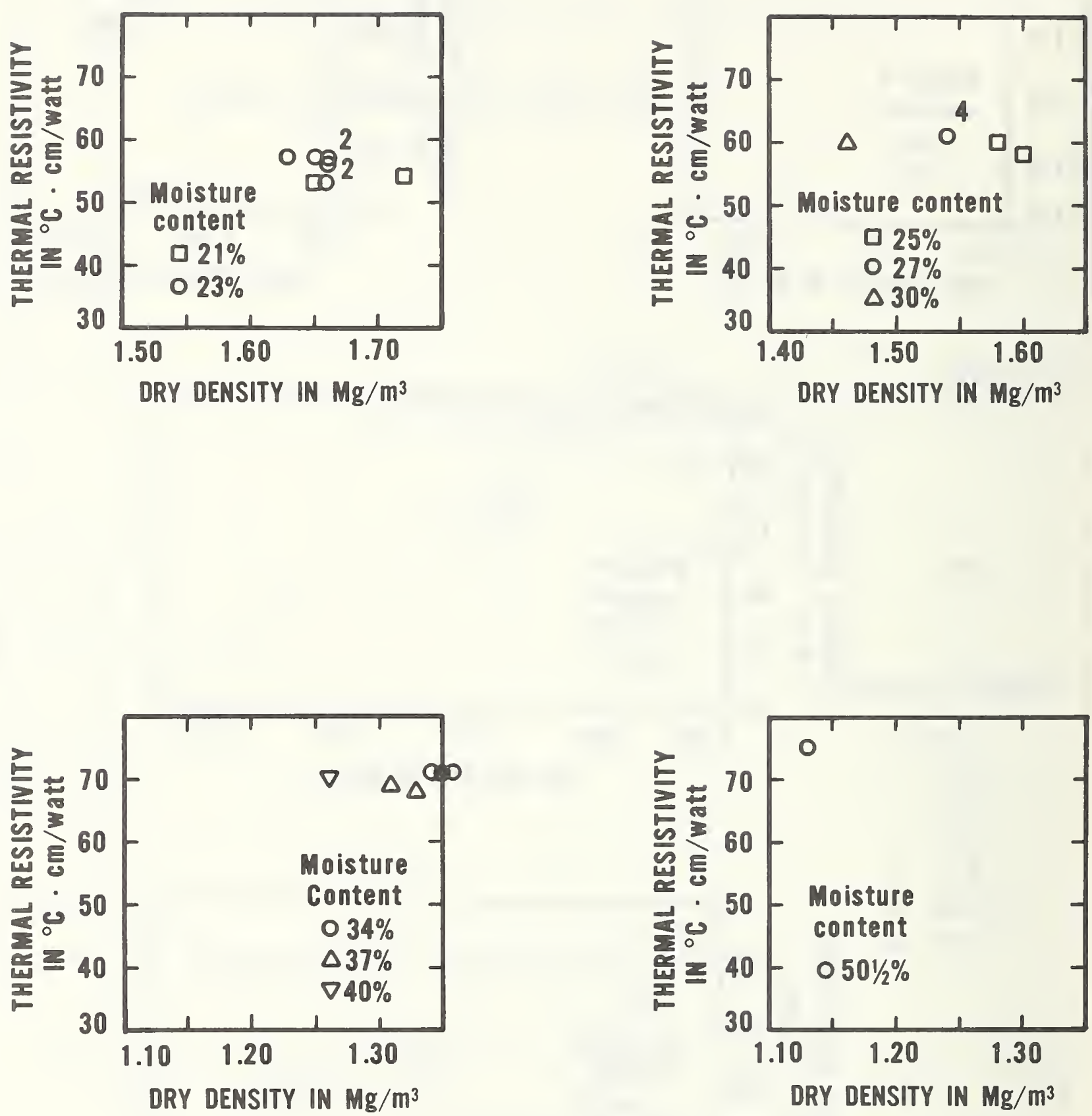

Note: $1 \mathrm{Mg} / \mathrm{m}^{3}=62.4 \mathrm{PCF}$

Figure 4-4. Variation of thermal resistivity with dry density for moisture contents of 21 percent to 50-1/2 percent 


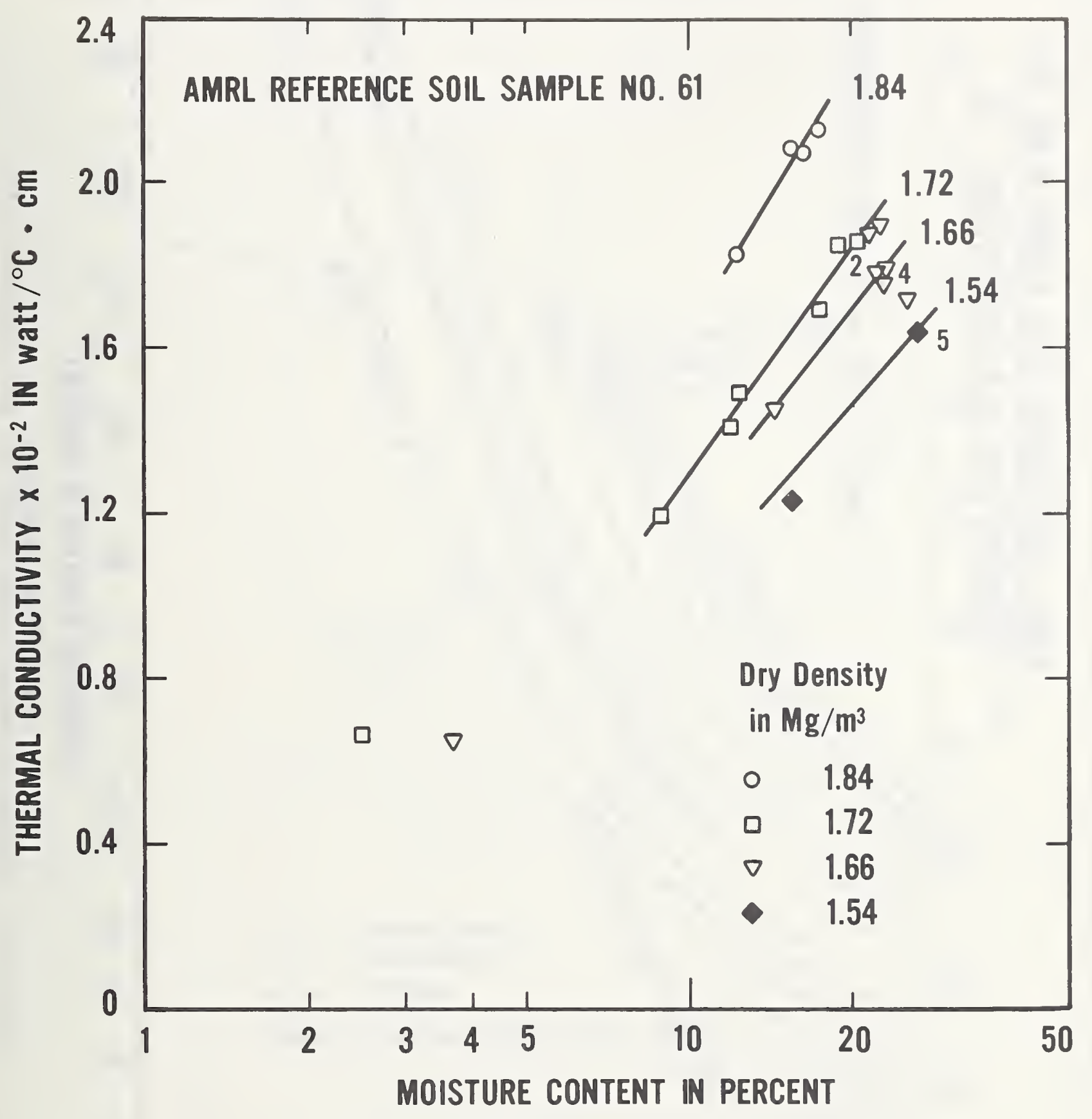

Figure 4-5. Variation of thermal conductivity with moisture content for various values of dry density 


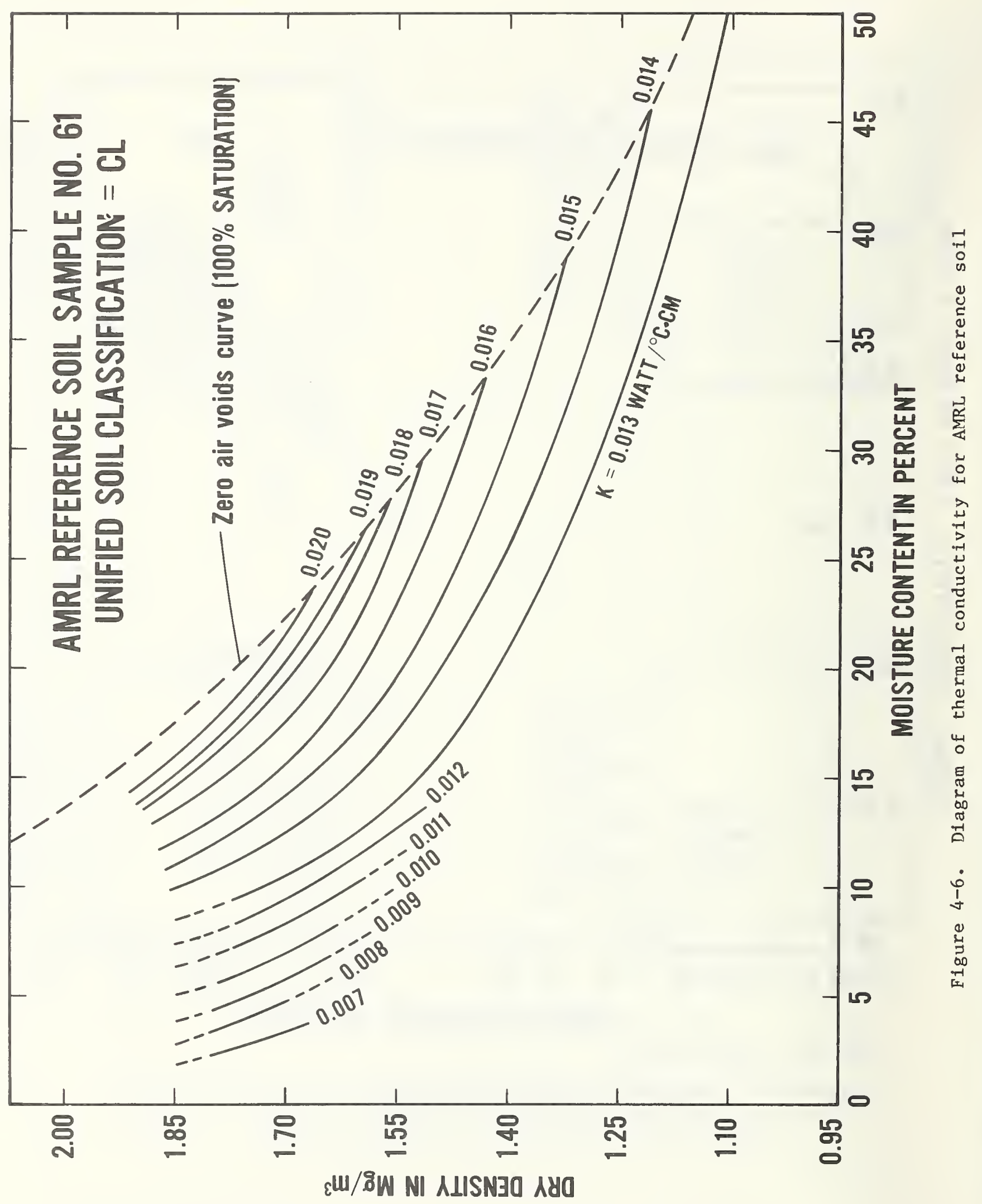




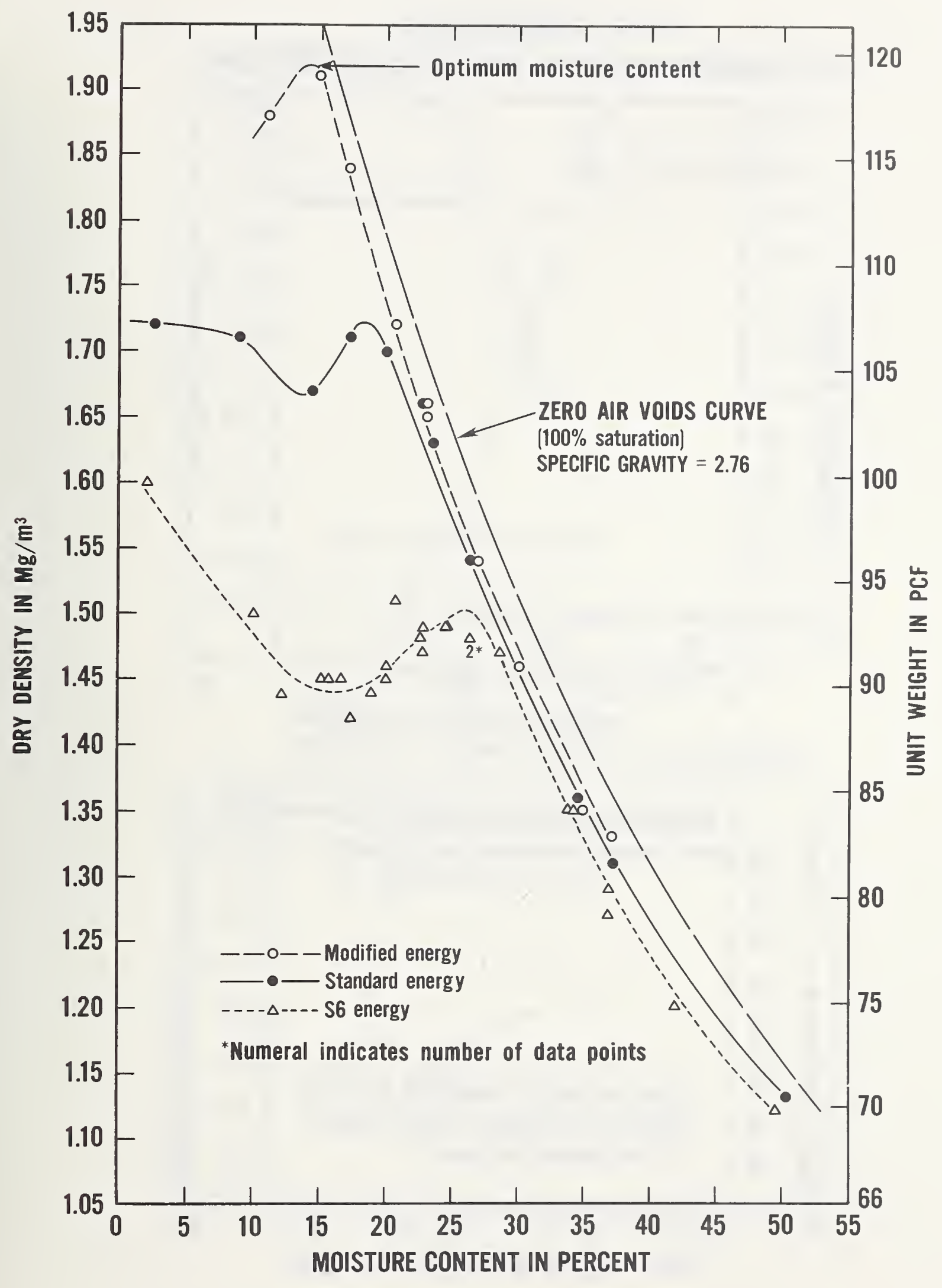

Figure 4-7. Compaction curves for modified, standard, and S6 energies 
MODIFIED ENERGY

MOISTURE - DENSITY RELATIONSHIP (COMPACTION CURVE)
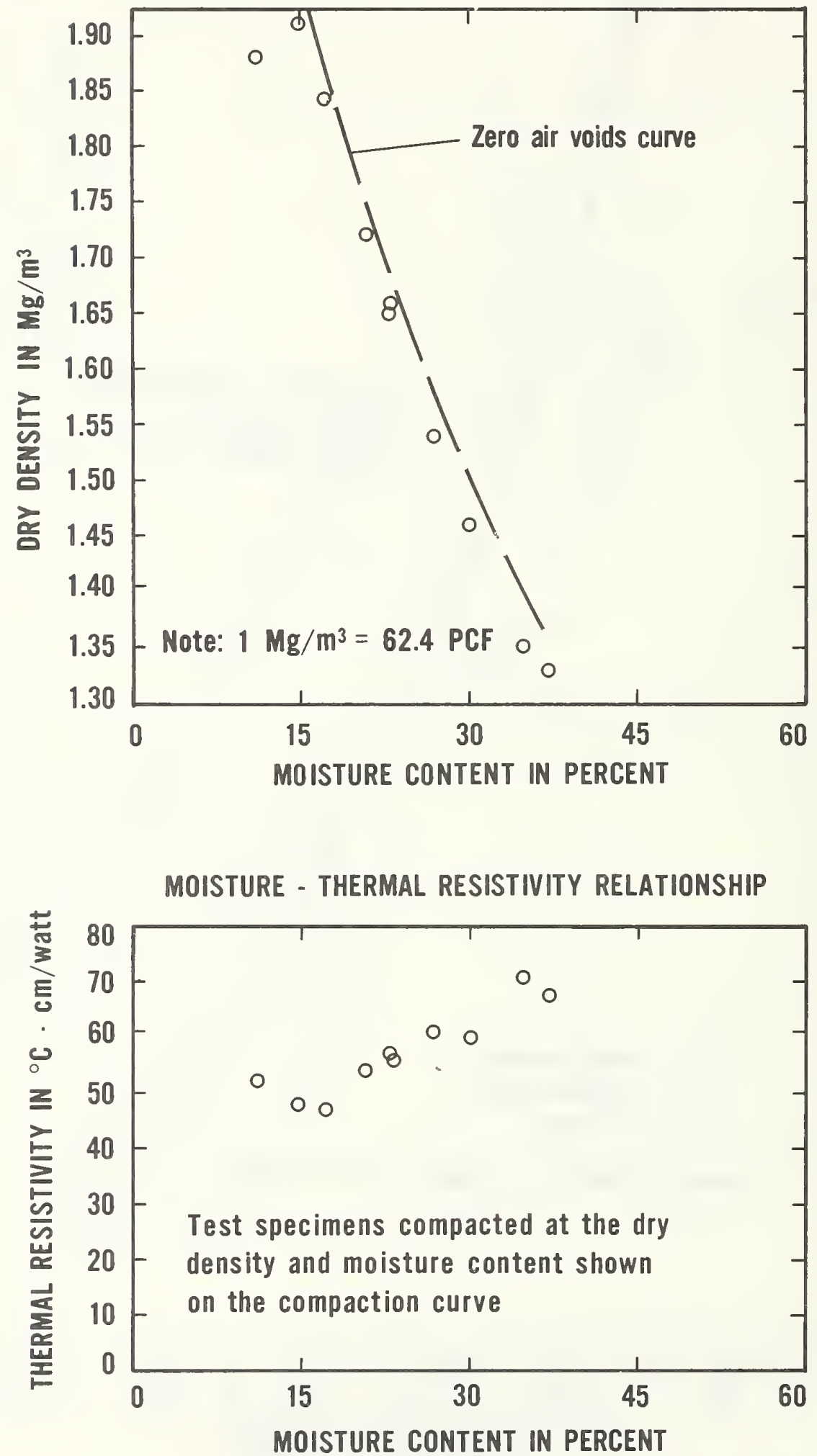

Figure 4-8. Correlation of modified energy moisture - density curve with thermal resistivity - moisture content curve 

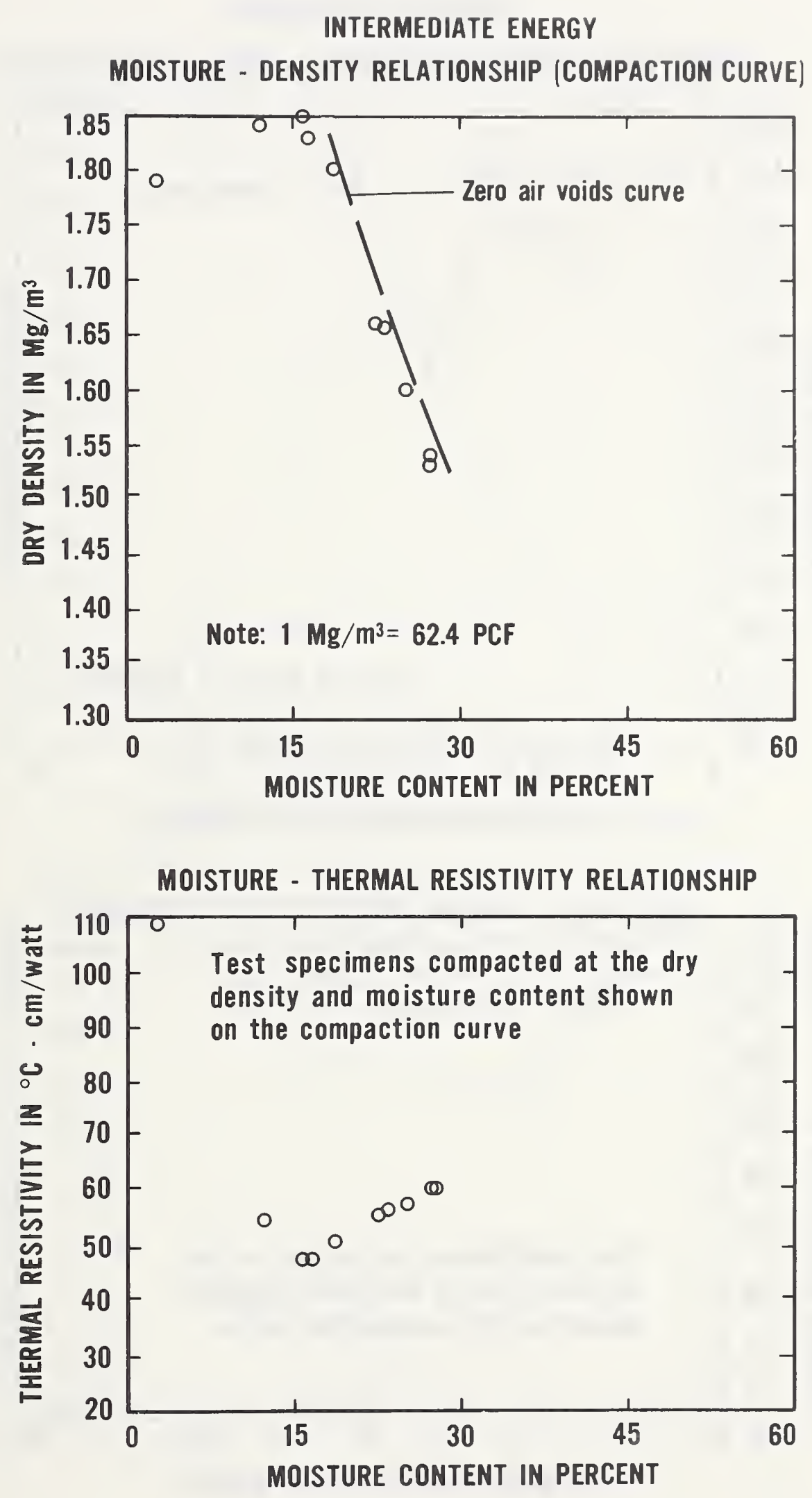

Figure 4-9. Correlation of intermediate energy moisture - density curve with thermal resistivity - moisture content curve 
STANDARD PLUS ENERGY

MOISTURE - DENSITY RELATIONSHIP (COMPACTION CURVE)
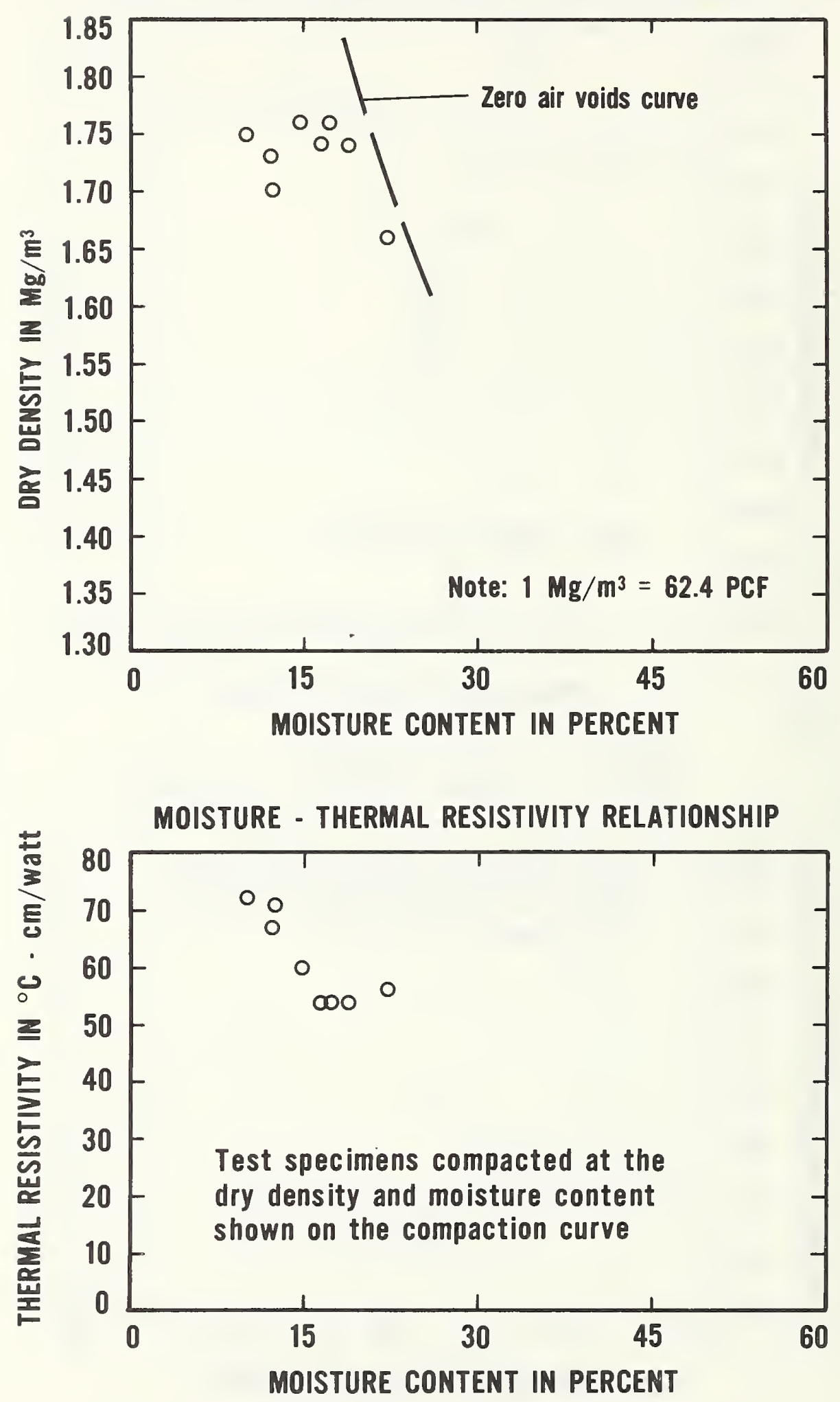

Figure 4-10. Correlation of standard plus energy moisture - density curve with thermal resistivity - moisture content curve 


\section{STANDARD ENERGY}

\section{MOISTURE - DENSITY RELATIONSHIP (COMPACTION CURVE)}

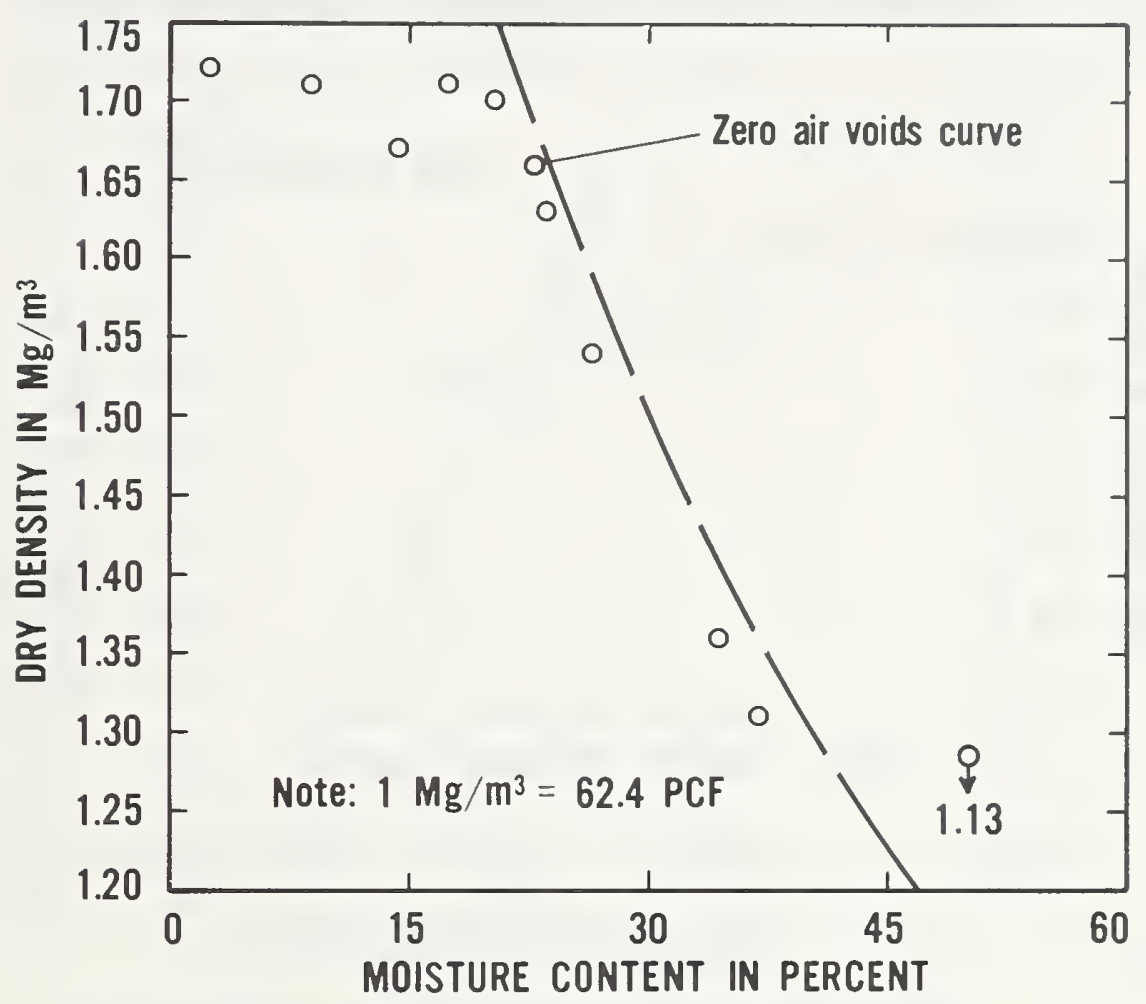

MOISTURE - THERMAL RESISTIVITY RELATIONSHIP

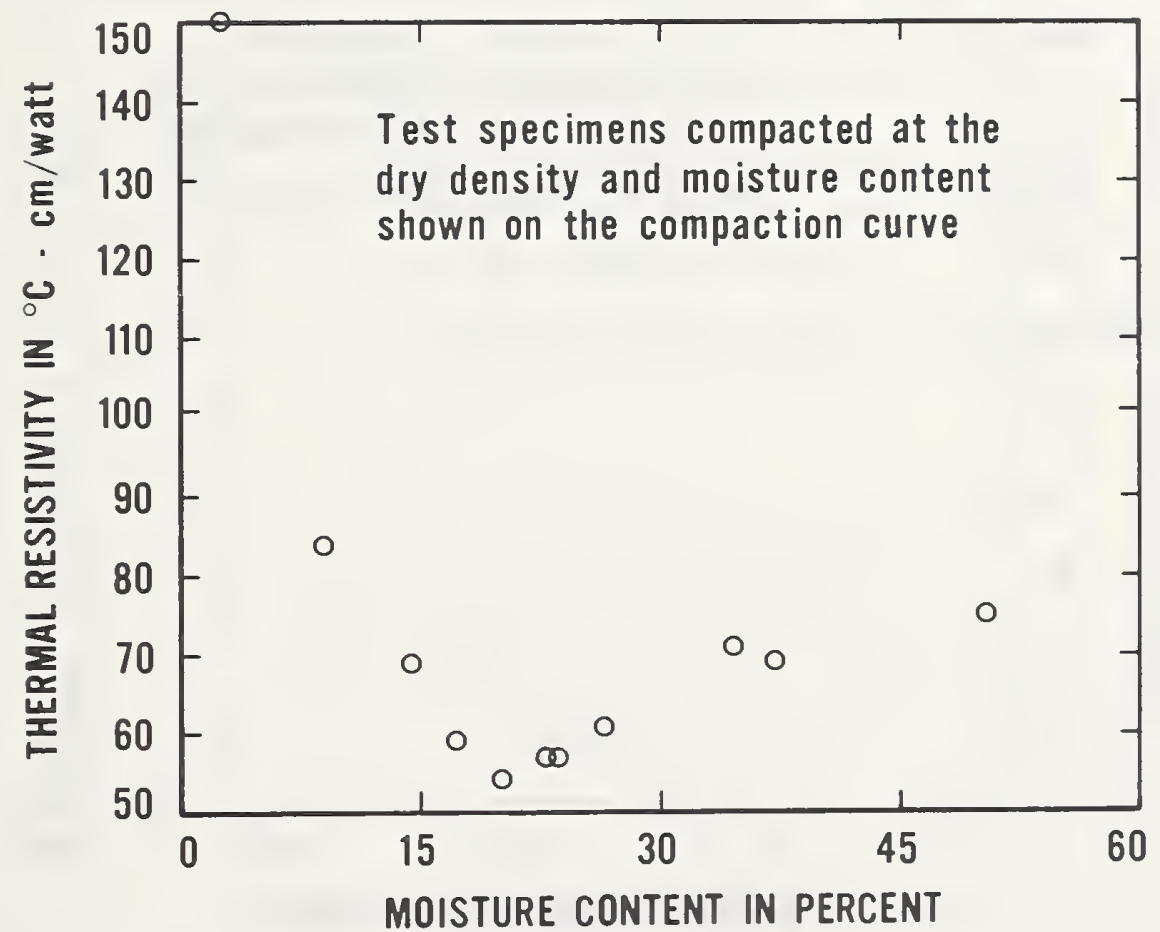

Figure 4-11. Correlation of standard energy moisture - density curve with thermal resistivity - molsture content curve 
S 12 ENERGY

MOISTURE -DENSITY RELATIONSHIP (COMPACTION CURVE)



MOISTURE - THERMAL RESISTIVITY RELATIONSHIP



F1gure 4-12. Correlation of S12 energy moisture - density curve with thermal resistivity - moisture content curve 
S6 ENERGY

MOISTURE - DENSITY RELATIONSHIP (COMPACTION CURVE)

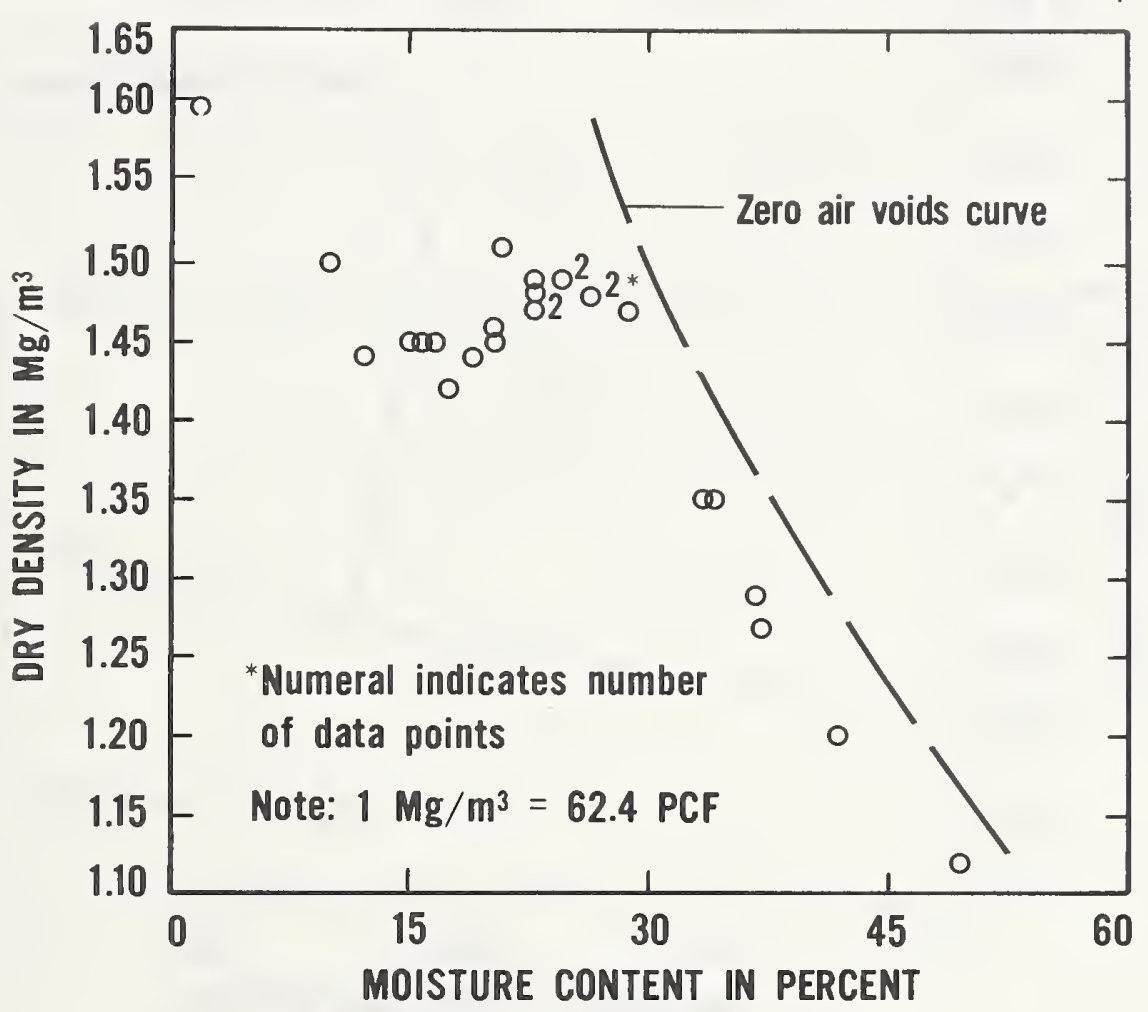

MOISTURE - THERMAL RESISTIVITY RELATIONSHIP



Figure 4-13. Correlation of S6 energy moisture - density curve with thermal resistivity - moisture content curve 


\section{S4 ENERGY}

MOISTURE - DENSITY RELATIONSHIP (COMPACTION CURVE)
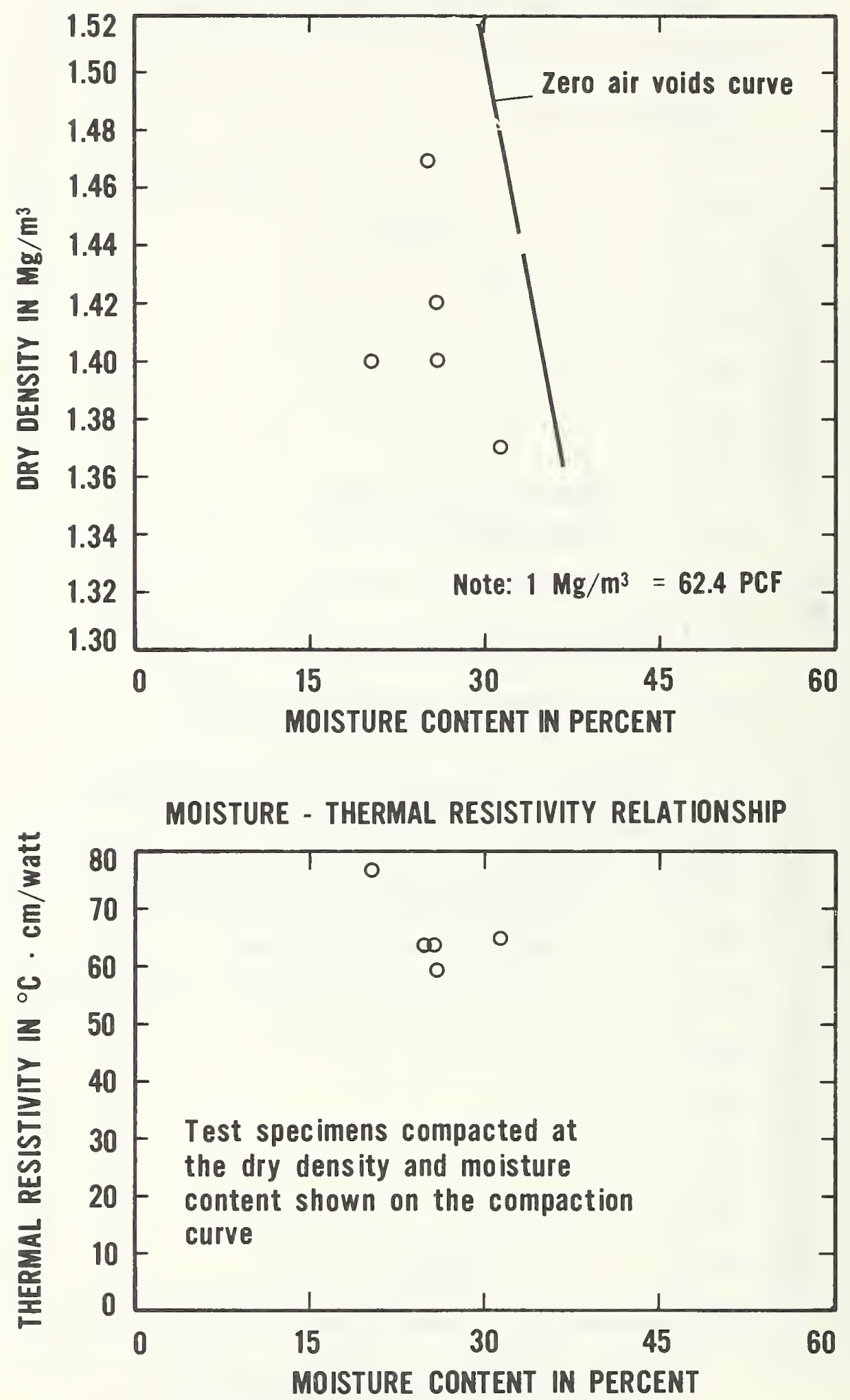

Figure 4-14. Correlation of S4 energy moisture - density curve with thermal resistivity - moisture content curve 




Figure 4-15. Variation of minimum thermal resistivity with compactive effort 


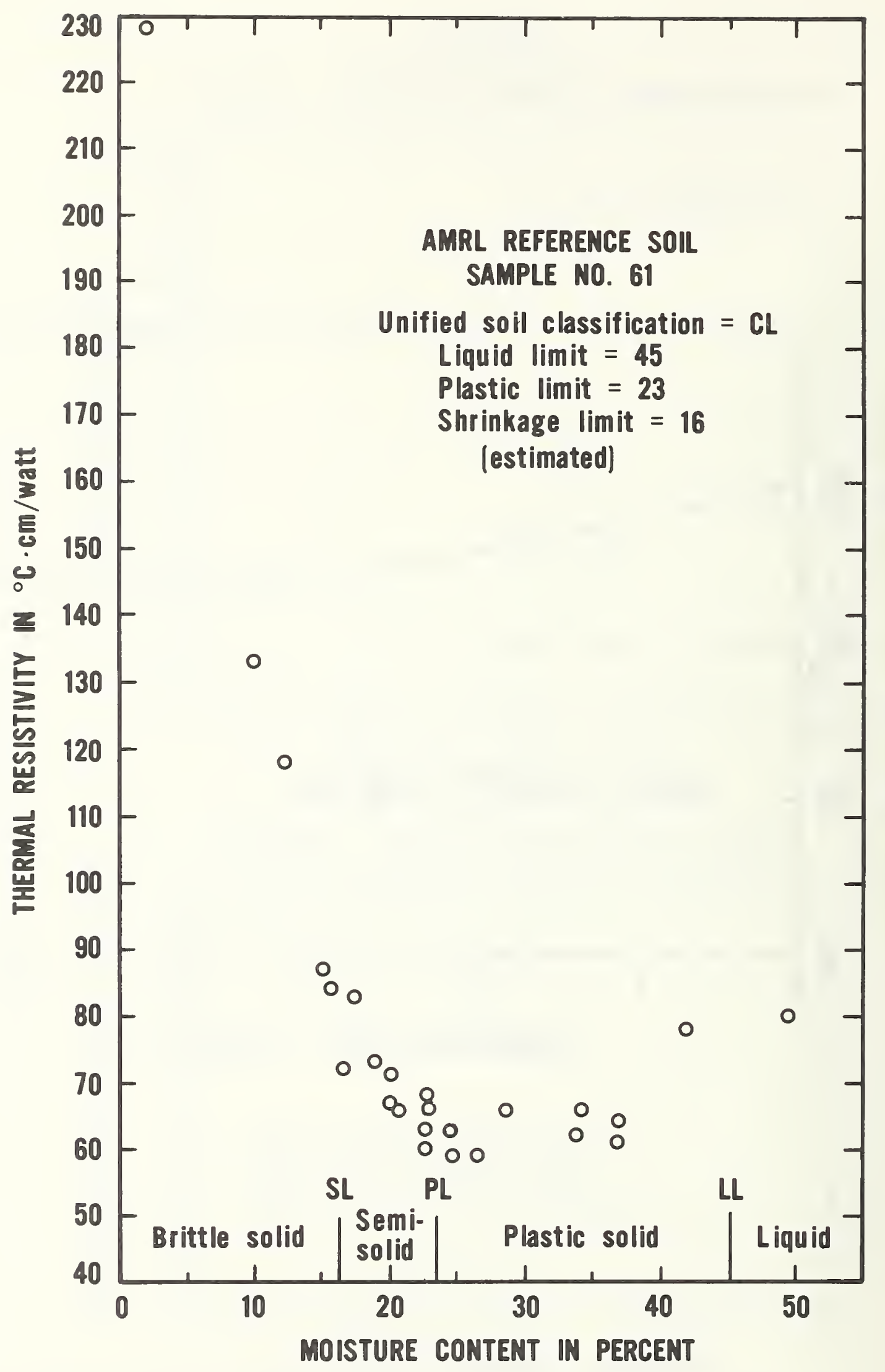

Figure 4-16. Correlation of thermal resistivity and Atterberg Limit test data using $\mathrm{S} 6$ compactive effort 


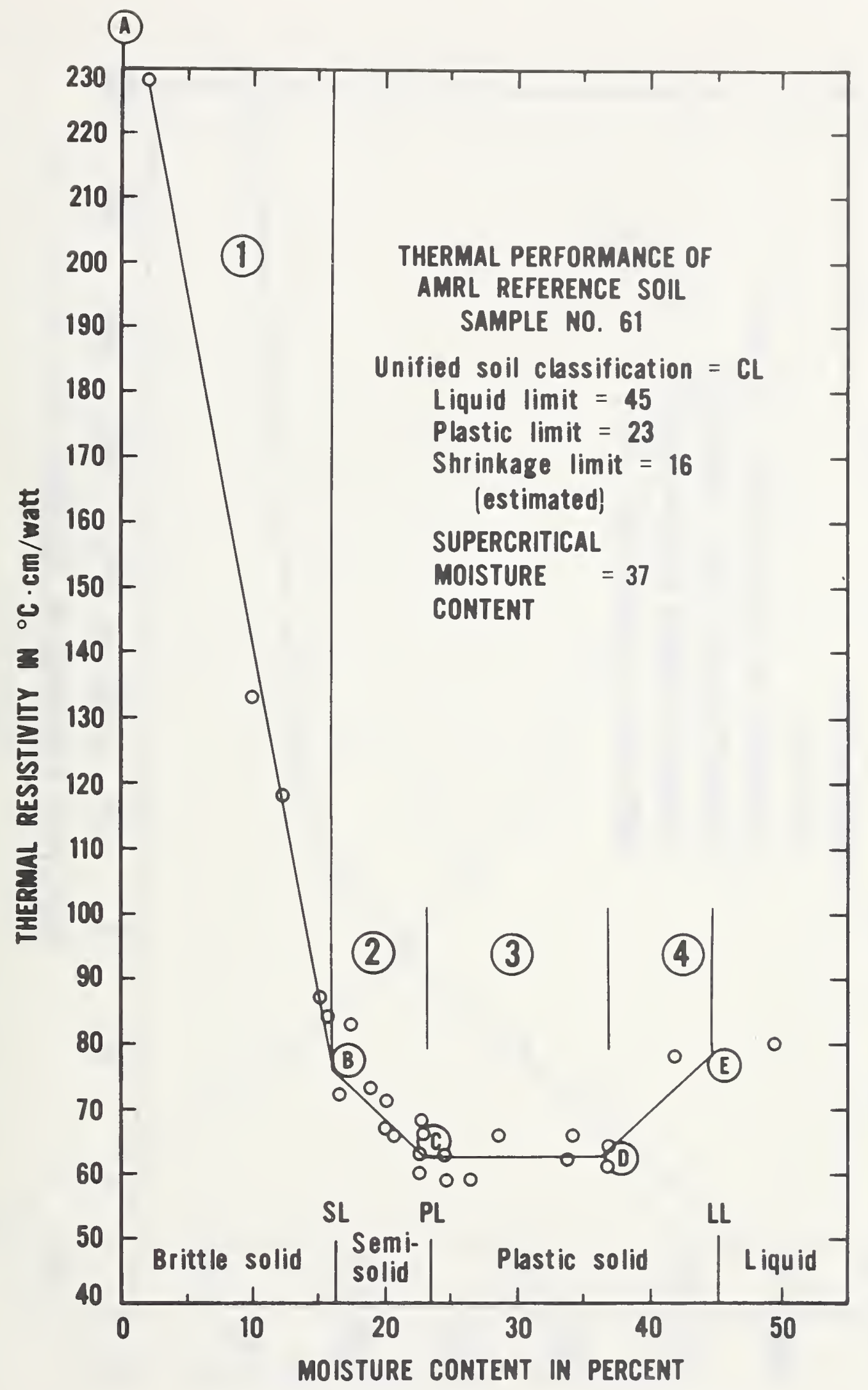

Figure 4-17. Thermal behavior of AMRL reference soil sample using 56 compactive effort 


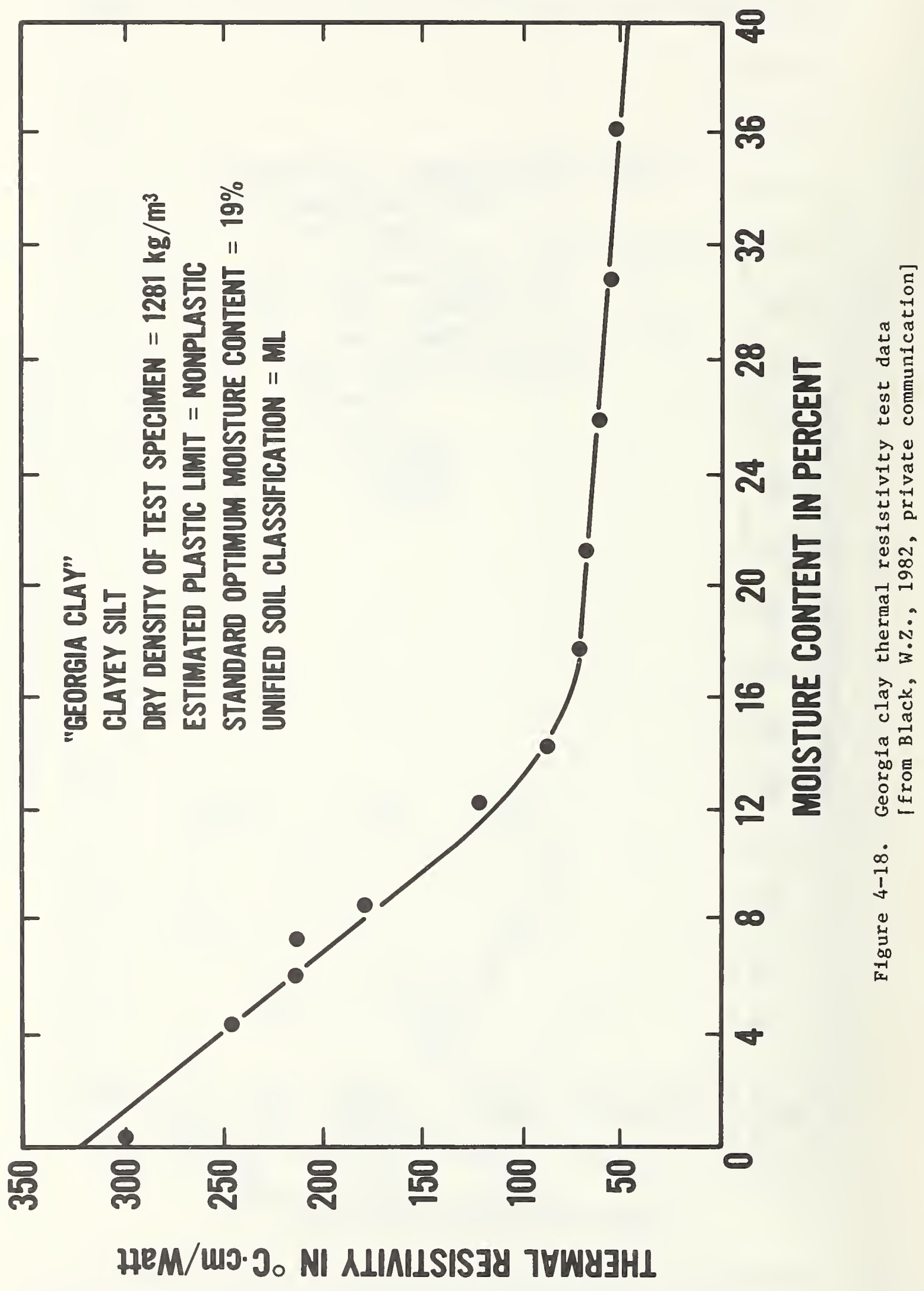




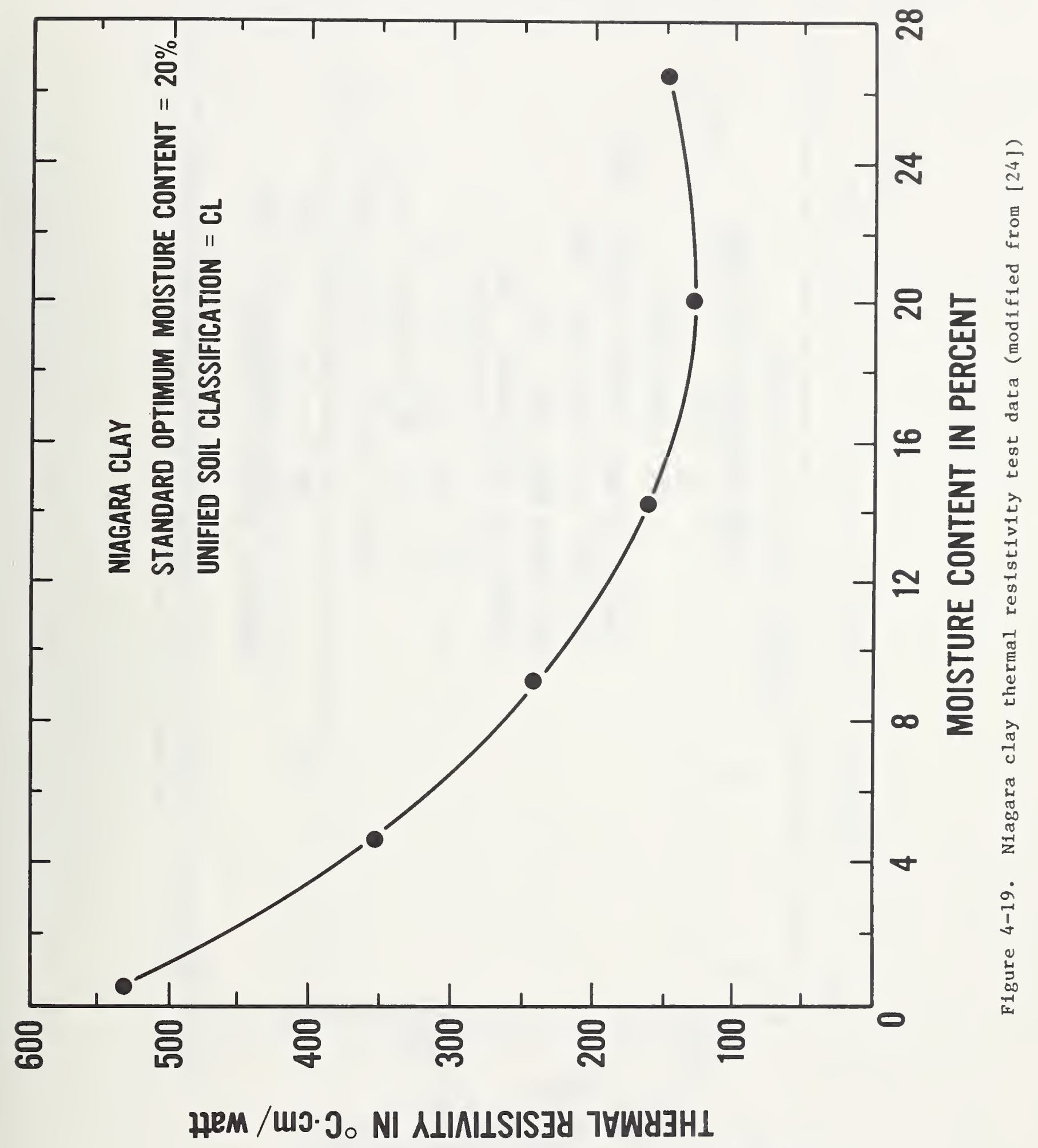




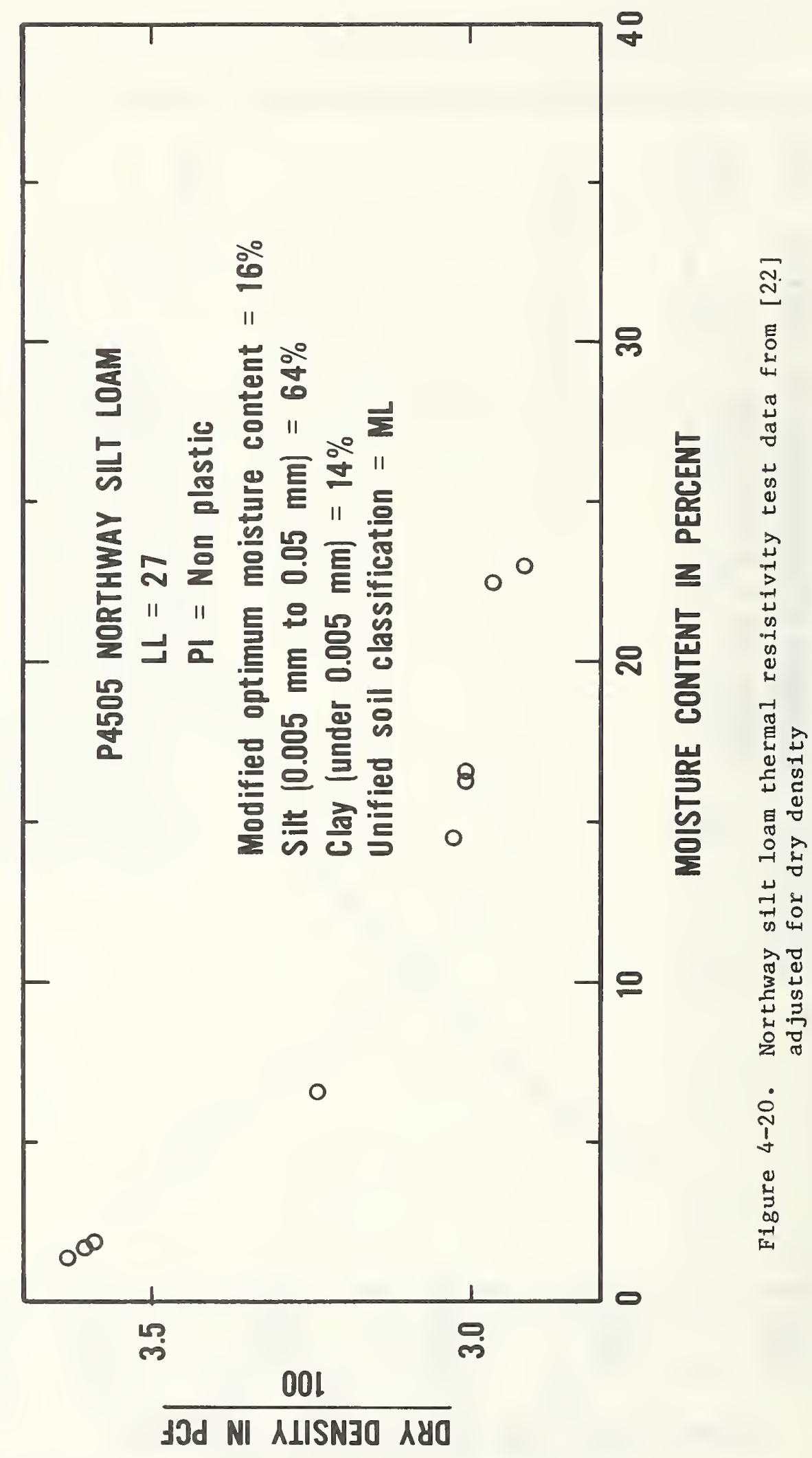






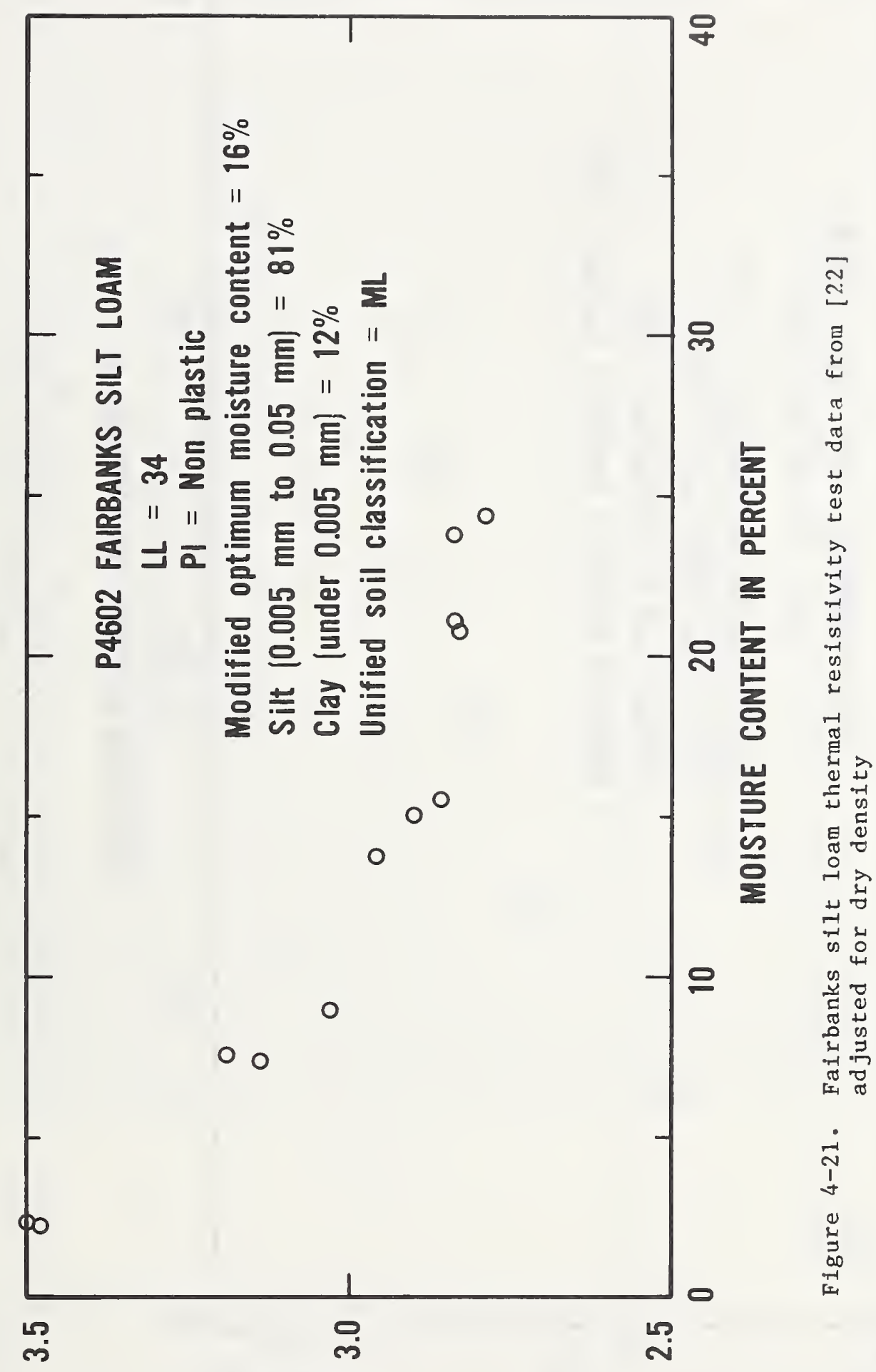

$\frac{001}{\text { Jad NI ADSN3a kya }}$

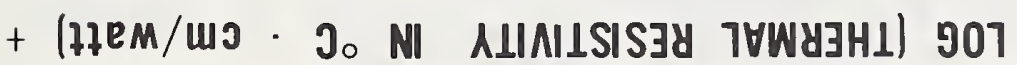









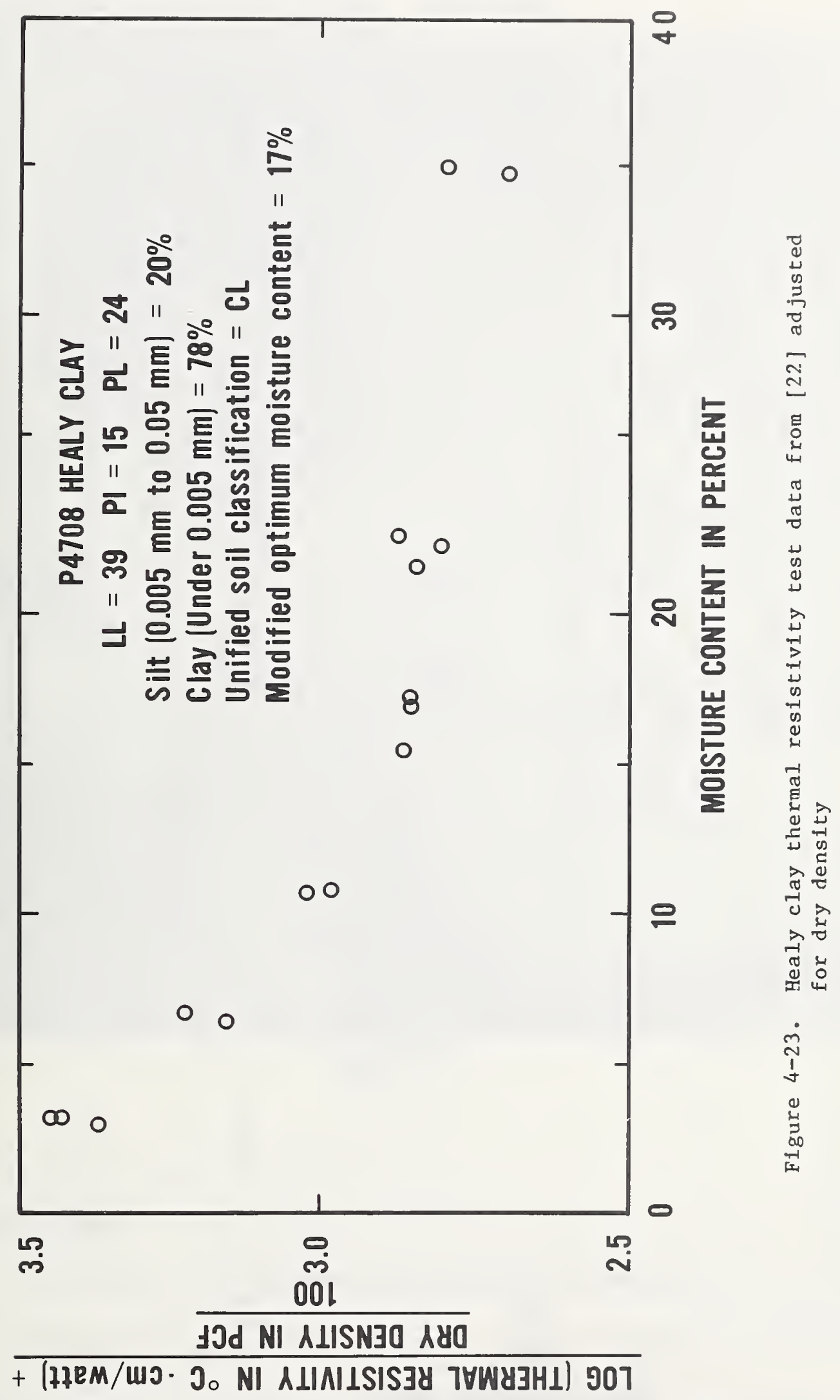


FACING PAGE: Inserting a 25-mm (1-in) diameter thin wall tuhe to obtain the inner core moisture content sample.

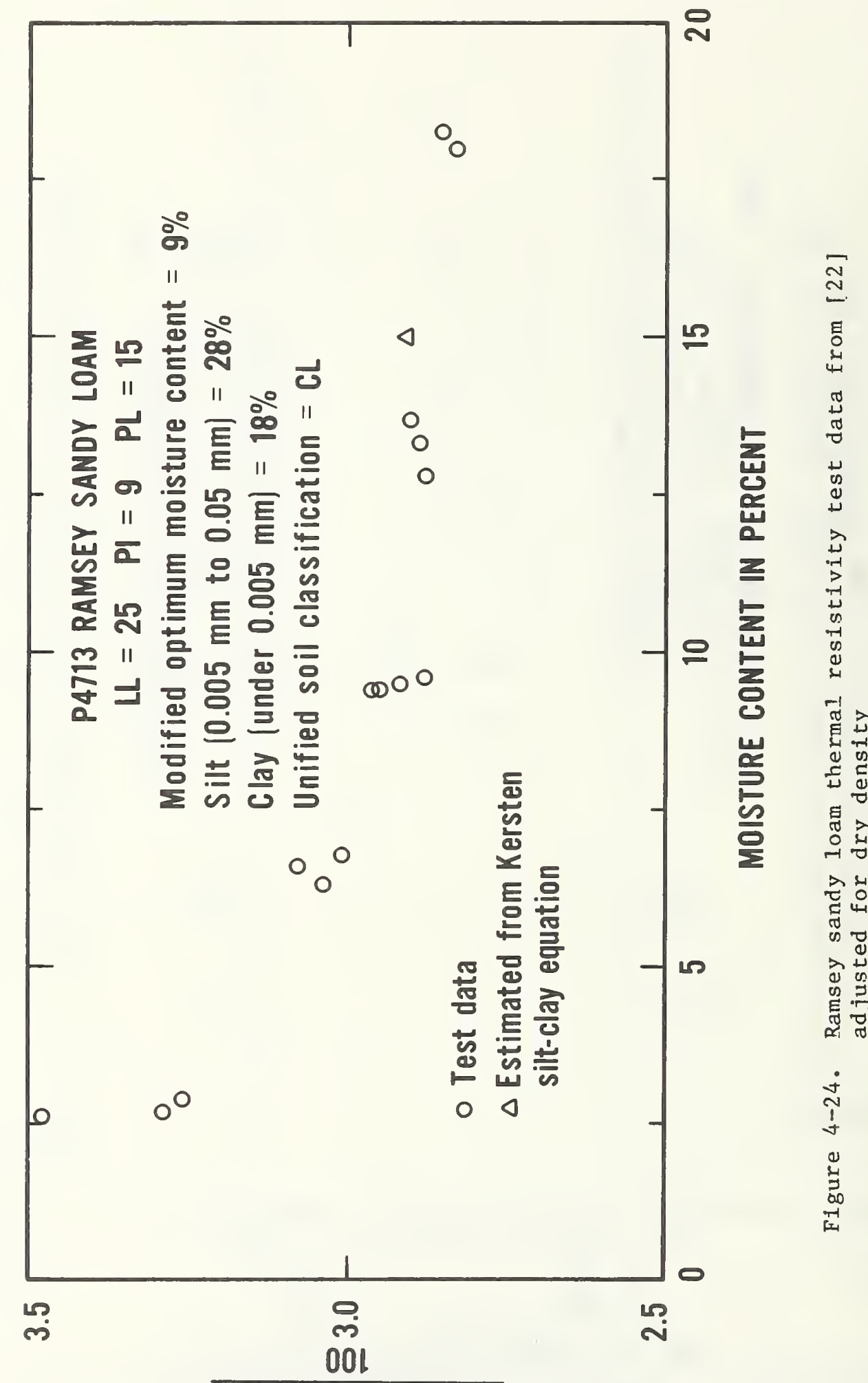

JOd NI ALISN30 180

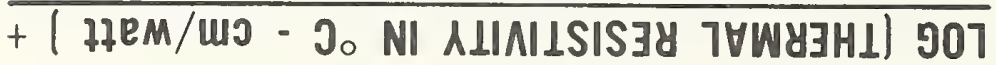




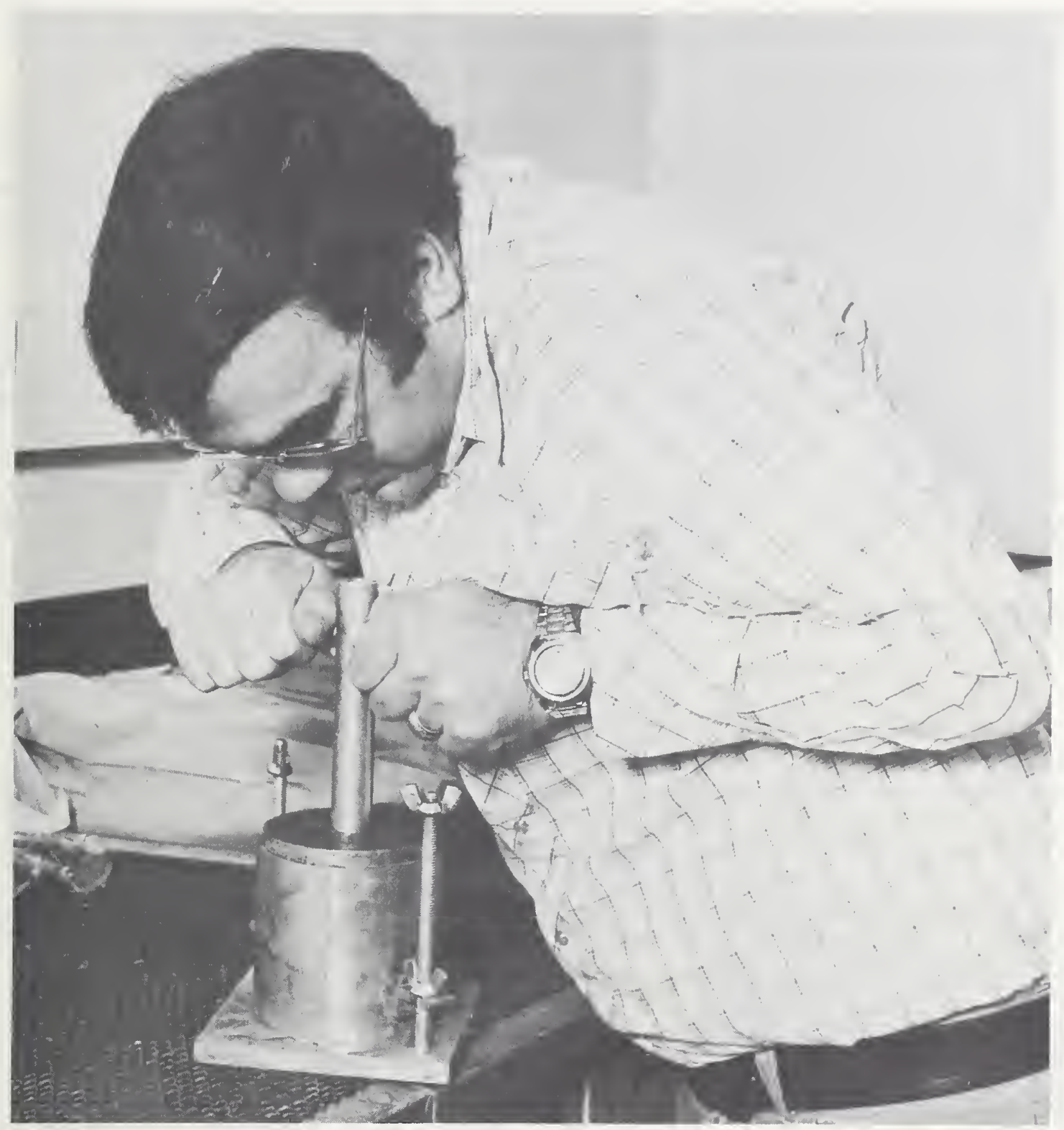

5. CONCLUSIONS AND RECOMMENDATIONS

\subsection{CONCLUSIONS}

Based on this study, the following conclusions are warranted:

1) The critical moisture content increases as the dry density of the soil decreases.

2) A large increase in thermal resistivity with a small change in moisture content occurs when the moisture content of the soil is less than the critical moisture content. 
3) As the compactive effort for preparing samples was decreased, a compactive effort $\left(1.42 \times 10^{5} \mathrm{~J} / \mathrm{m}^{3}\right)$ that resulted in the critical moisture content, optinum moisture content and plastic limit being approximately equal was found.

4) The index property and thermal resistivity test data obtained for the AMRL reference soil and other fine-grained soil indicate that the critical moisture content can be defined by the optimum moisture content. The compactive effort chosen to determine the optimum moisture content will depend on the dry density for which the critical moisture content is being defined.

5) The Thermal Performance Index, TPI, provided an indication of the thermal performance of the AMRL reference soil under saturated conditions. It measured the change in thermal resistivity per unit change in moisture content over the range of densities expected under natural or artificial (man-made) field conditions.

6) The Thermal Stability Index, TSI, defined in this study provided an approximate approach for evaluating the thermal stability of the AMRL soil using the moisture content of the soil expected under design conditions.

\subsection{RECOMMENDATIONS}

Based on this study the following recommendations are made:

1) The approach developed for this study was useful when establishing the thernal behavior of the AMRL reference soils. Because classification and thermal properties of fine-grained soils are not generally found in the literature, other researchers are encouraged to use the approach described in this study when measuring and reporting the thermal properties of soils.

2) The concepts used to establish the thermal behavior of the AMRL soil should be studied further using a wide variety of soils, and exceptions, if any, to the general trends should be identified.

3) A dry density or the compactive effort used to prepare the samples should be specified when defining the critical moisture content. The dry density specified can be the in situ dry density (natural) or a dry density which is a percentage of the laboratory maximum dry density determined by some standard test, e.g. standard Proctor test (ASTM D698-78 procedures) or the modified Proctor test (ASTM D1557-78 procedures).

4) Correlations of index properties and the thermal behavior of soils provide a cost effective method for assessing the probable thermal performance of soils in an engineering situation. These correlations should be used in conjunction with those thermal property measurements required to evaluate system performance (viz: underground power cables, heat storage, heat loss into ground and frost penetration) over the range of operating conditions expected.

FACING PAGE: Extrusion of the remaining compacted sample using soil extruder for total moisture content determination. 


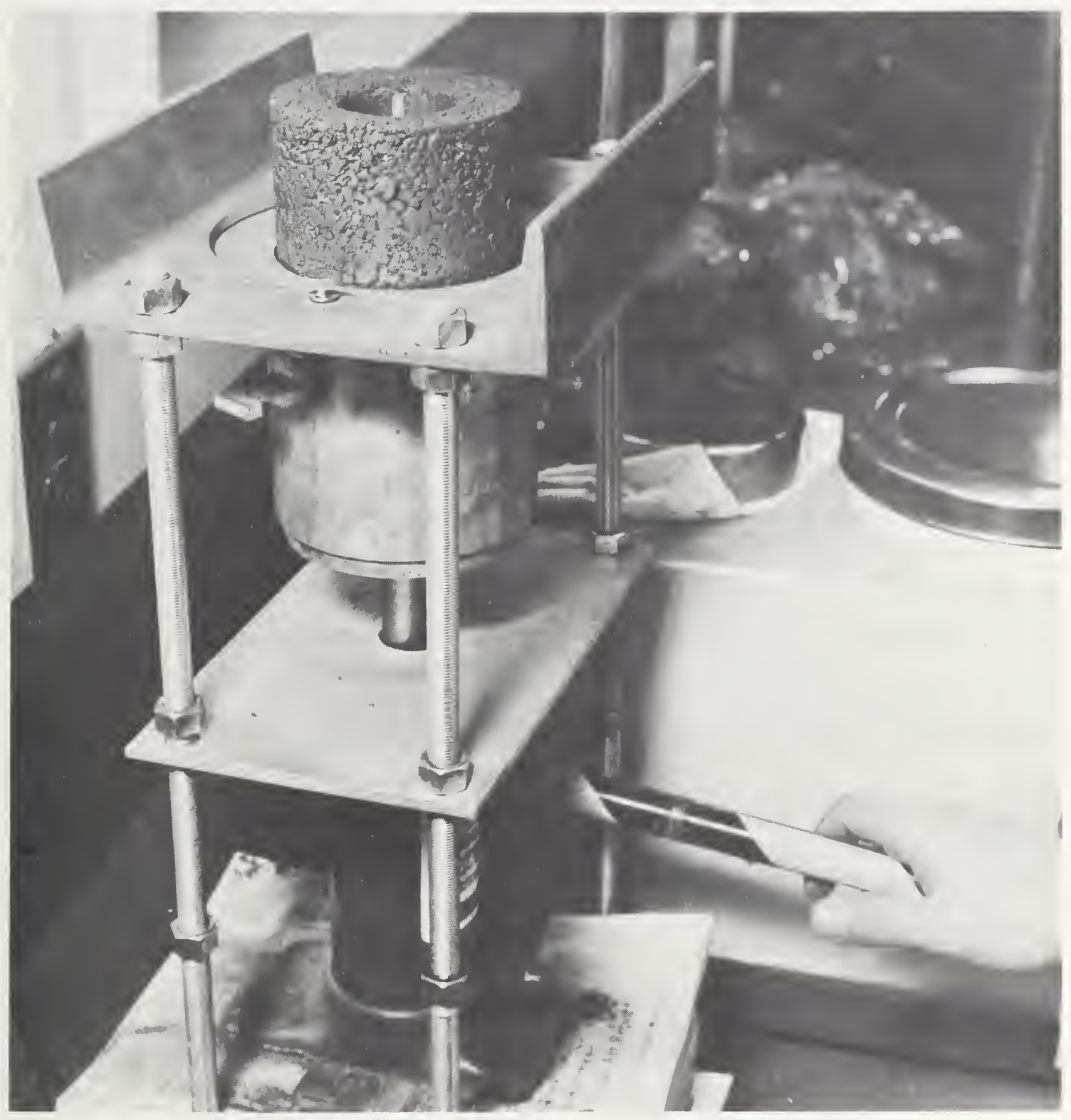

\section{ACKNOWLEDGMENTS}

The writers wish to thank J. Lichtenberg and H. Puluzzi of Potomac Electric Power Company (PEPCO) and T. Rodenbaugh of the Electric Power Research Institute (EPRI) for making the necessary arrangements which allowed us to use the EPRI Thermal Property Analyzer during the study. The useful discussions with T. Rodenbaugh of EPRI, H. S. Radhakrishna, S. Boggs, and J. Steinmanis of Ontario Hydro and D. Parmer of Geotherm, Inc. about the equipment used in the study and their experience in thermal property measurements was also greatly appreciated. The writers wish to thank those providing index and thermal property data on other types of soil: H. S. Radhakrishna of Ontario Hydro, D. Parmer of Geotherm, Inc., W. Murphy and D. Horna of Dames and Moore, W. Black 
of Georgia Tech, T. Nishioka of Arizona Public Service Company, and D. Slack, $\mathrm{J}$. Mostaghimi and J. Ramsey of the University of Minnesota. In the case of $T$. Nishioka of Arizona Public Service Company and D. Slack of the University of Minnesota, obtaining the required index property data involved performing additional index property tests. Their special effort is greatly appreciated by the writers.

The writers also acknowledge the assistance of 0 . W. McIntosh of the AASHTO Materials Reference Laboratory who made the necessary arrangements for obtaining the required quantities of soll used in the testing program and $W$. Liggett of the NBS Statistical Engineering Group for his assistance in analyzing the thermal resistivity test data. H. S. Radhakrishna of Ontario Hydro reviewed the report. His comments and suggestions are greatly appreciated. A special thanks is also given to Brenda Thompson for typing this report. 


\section{REFERENCES}

[1] American Institute of Electrical Engineers "Soil Thermal Characteristics in Relation to Underground Power Cables," Proceedings from Summer General Meeting, Atlantic City, New Jersey, 1960, 67 pp.

[2] Fink, L. H., Discussion of "Thermal Instability and its Prediction in Cable Backfill Soils," Radhakrishna, H. S. and others (1980). IEEE Transactions on Power Apparatus and Systems. Vol. PAS-99, No. $\overline{3,1980,}$ p. 865 .

[3] Holtz, R. D. and Kovacs, W. D., An Introduction to Geotechnical Engineering, Prentice-Hall, Inc., Englewood Cliffs, New Jersey, 1981, pp. 26-27.

[4] Salomone, L. A., "Improving Geotechnical Investigations for Underground Transmission Lines" in Underground Cable Thermal Backfill, Toronto:

Pergamon Press; 1982, pp. 57-71.

[5] Wechsler, A. E., "Development of Thermal Conductivity Probes for Soils and Insulations," USA Cold Regions Research and Engineering Laboratory, Technical Report 182, 1966, 83 pp.

[6] Carslow, H. S. and Jaeger, J. C., Conduction of Heat in Solids, 2nd ed., Oxford University Press, London, 1959.

[7] Jahnke-Emde-Lösch, Tables of Higher Functions, McGraw-Hil1 Book Company, Inc., New York, 1960 .

[8] Ontario Hydro Research Laboratory, "Soil Thermal Resistivity and Thermal Stability Measuring Instrument, Volume 2: Manual for Operation and Use of the Thermal Property Analyzer and Statistical Weather Analysis Program to Determine Thermal Design Parameters," EPRI Final Report No. EL-2128, 1981, $41 \mathrm{pp}$.

[9] American Association of State Highway and Transportation Officials. Standard Specifications for Transportation Materials and Methods of Sampling and Testing (1978) Part II, Washington, D.C. T87 (pp. 247-249), T88 (pp. 250-263), T89 (pp. 263-270), T90 (pp. 271-272), T99 (pp. 292-299), T100 (pp. 299-302), T180 (pp. 570-577), T190 (pp. 591-601).

[10] AASHTO Materials Reference Laboratory, "Report for Soil Reference Samples 61 and 62," National Bureau of Standards, Washington, D.C., 1981, 23 pp.

[11] U.S. Army Engineer Waterways Experiment Station, "The Unified Soil Classification System," Technical Memorandum No. 3-357. Appendix A, Characteristics of Soil Groups Pertaining to Embankments and Foundations, 1953; Appendix B, Characteristics of Soil Groups Pertaining to Roads and Airfields, 1957, 1960.

[12] American Society for Testing and Materials Annual Book of ASTM Standards, Soil and Rock, Building Stones, Part 19, Philadelphia, 1981, pp. 113-123. 
[13] Sinclair, W. A., Buller, F. H., and Benham, C. B., "Soll Therma1 Resistivity; Typical Field Values and Calculating Formulas," Part IV of a report of the American Institute of Electrical Engineers [1], 1960, pp. 31-43.

[14] Winterkorn, H. F., "Behavior of Moist Soils in a Thermal Energy Field," Clays and Clay Minerals, Vo1. 9, Pergamon Press, Oxford, 1962, pp. 85-103.

[15] Salomone, L. A., Singh, H., and Fischer, J. A., "Geotechnical Considerations for Designing Underground Transmission Lines," presented at the 1979 Transmission and Distribution Conference and Exposition, Atlanta, Georgia, 1979.

[16] Radhakrishna, H. S., Chu, F. Y., and Boggs, S. A., "Thermal Instability and Its Prediction in Cable Backfill Soils," IEEE Transactions on Power Apparatus and Systems, Vo1. PAS-99, No. 3, 1980, pp. 856-867.

[17] Fink, L. H., "Soil Moisture Characteristics," Part II of a report of the American Institute of Electrical Engineers [1], 1960, pp 803-819.

[18] Kohnke, H., Soil Physics, McGraw-Hill Book Company, New York, New York, 1968, pp. 49-54.

[19] Gowda, K. R. S. and Winterkorn, H. F., (1949) "Theoretical and Experimental Exploration of the Practical Possibilities of Electrosmosis: Final Report on Beach Stabilization Research (1947-1949)," Part V, Bureau of Yards and Docks, U.S. Navy, NO. y-15087, 1949, pp. 454-562.

[20] Atterberg, A.,.."Lerornas Förhallande till Vatten, deras Plasticitetsgranser och Plasticitetsgrader," ("The Behavior of Clays with Water, their Limits of Plasticity and the Degrees of Plasticity,") Kungliga Lantbruksakademiens Handlingar och Tidskrift, Vo1. 50, No.2, 1911, pp. 132-158; also in Internationale Mitteilungen für Bodenkunde, Vol. 1, pp. 10-43 ("Uber die Physikalische Bodenuntersuchung und über die Plastizität der Tone").

[21] Casagrande, A., "Research on the Atterberg Limits of Solls," Public Roads, Vol. 13, No. 8, 1932, pp 121-136.

[22] Kersten, M. S., "Thermal Properties of Sol1s," Bulletin 28, Engineering Experiment Station, University of Minnesota, Minneapolis, 1949, $225 \mathrm{pp}$.

[23] Russel1, E. A. and Mickle, J. L., "Correlation of Suction Curves with the Plasticity Index of Soils," Journal of Materials, JMLSA, Vol. 6, No. 2, June 1971, pp. 320-331.

[24] Adams, J. and Baljet, A., "The Thermal Behavior of Cable Backfill Materials," IEEE Transactions on Power Apparatus and Systems, Vo1. PAS-87, No. 4, 1968, pp. 1149-1161. 
[25] Radhakrishna, H. S. and Steinmanis, J. E., "Ontario Hydro-General Public Utility Interconnection Lake Erie Marine Cable Crossing Thermal Resistivity Surveys," Ontario Hydro Research Division Report 81-378-K, 1981.

[26] Allison, R. W., Cheng, C. L., Griffiths, K. G., and Jue, J. S., "Thermal Resistivities of Ocean Sediment," In Underground Cable Thermal Backfill, S.A. Boggs et al., Eds., Pergamon Press, Toronto, 1982, pp. 110-118.

[27] Steinmanis, J. E., "Thermal Property Measurements Using a Thermal Probe," in Underground Cable Thermal Backfill, S.A. Boggs et al., Eds., Pergamon Press, Toronto, 1982, pp. 72-85. 

APPENDIX A - TABULATION OF DATA

$\mathrm{A}-1$ 



\begin{tabular}{|c|c|}
\hline  & 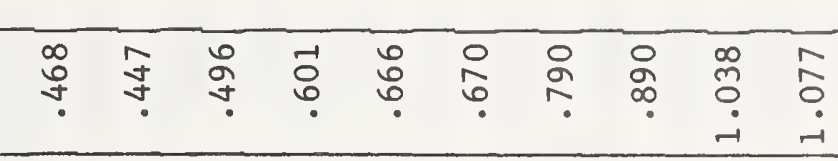 \\
\hline & 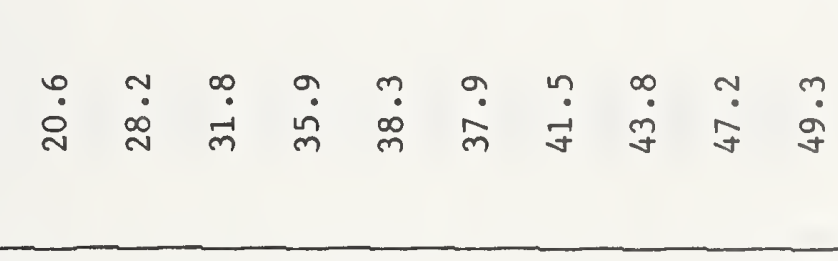 \\
\hline & 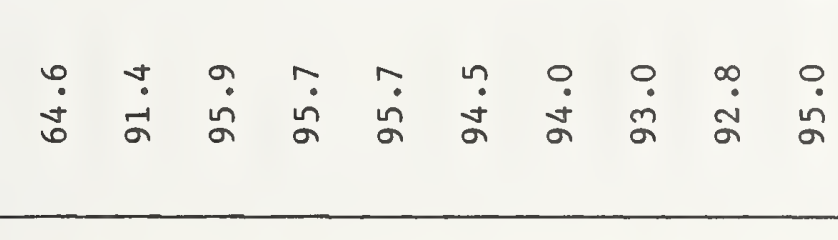 \\
\hline & 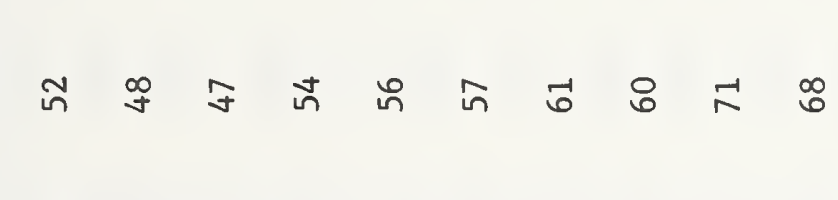 \\
\hline 䇏贯 &  \\
\hline & 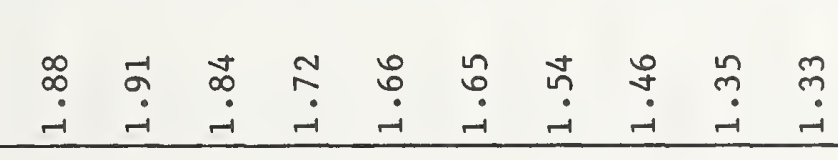 \\
\hline & 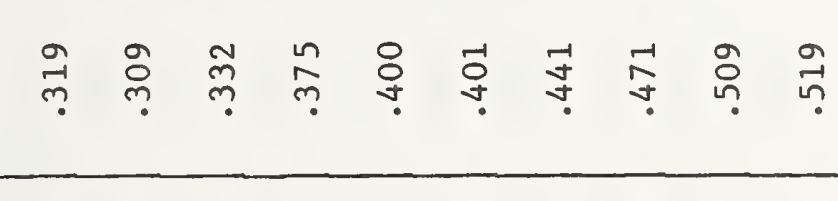 \\
\hline & 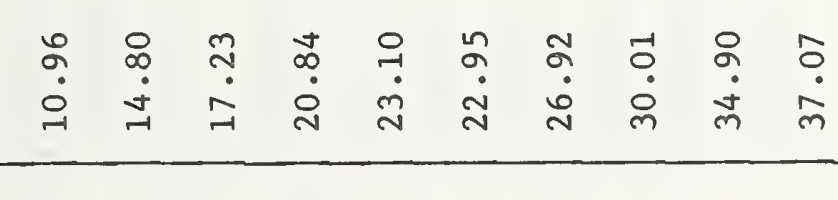 \\
\hline  &  \\
\hline 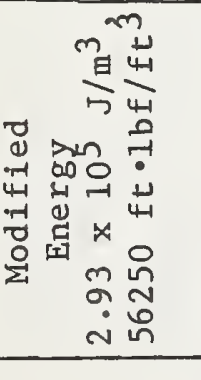 & 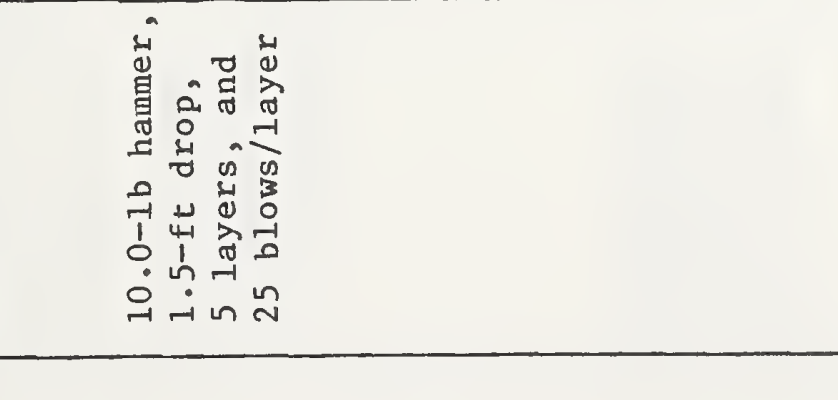 \\
\hline
\end{tabular}




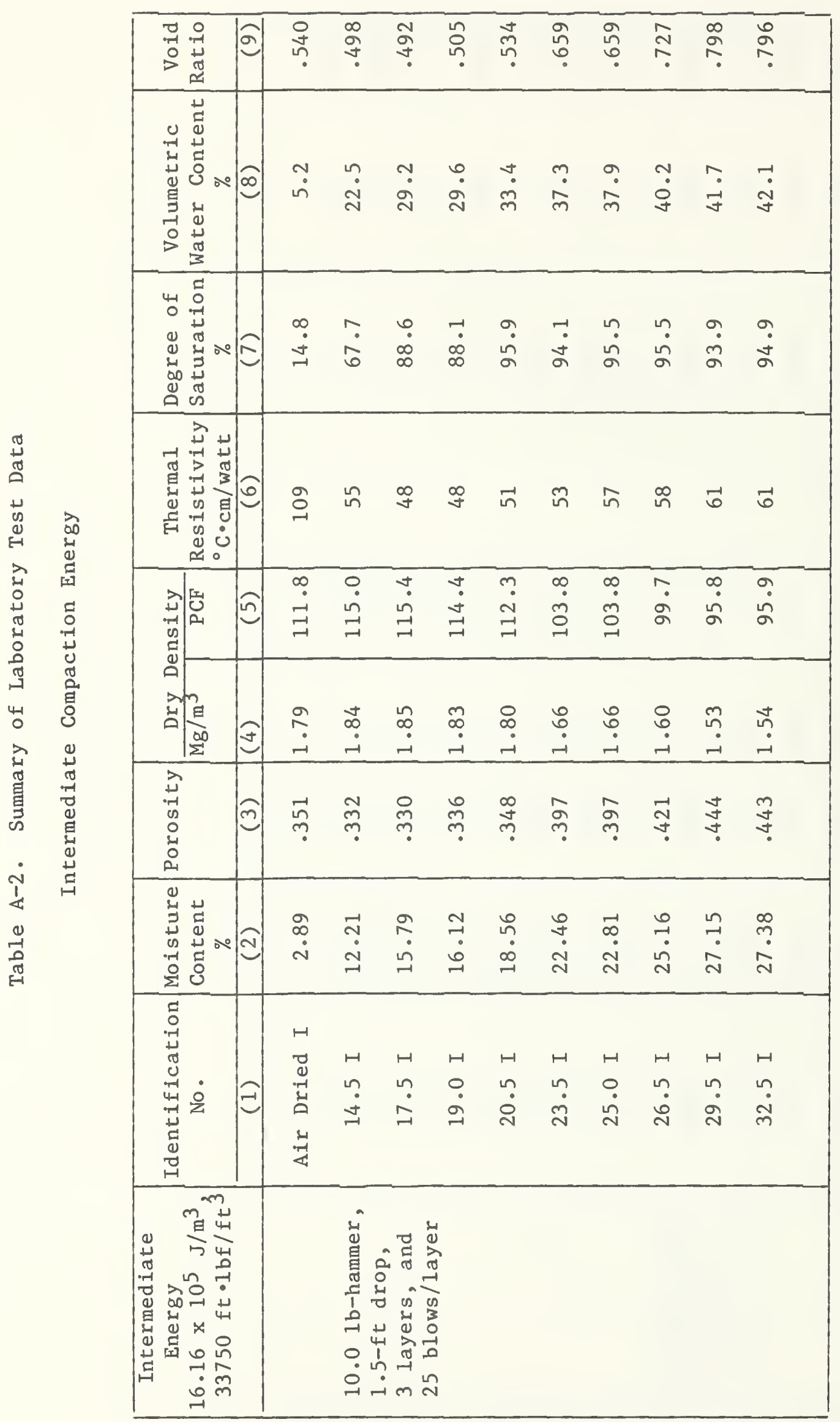




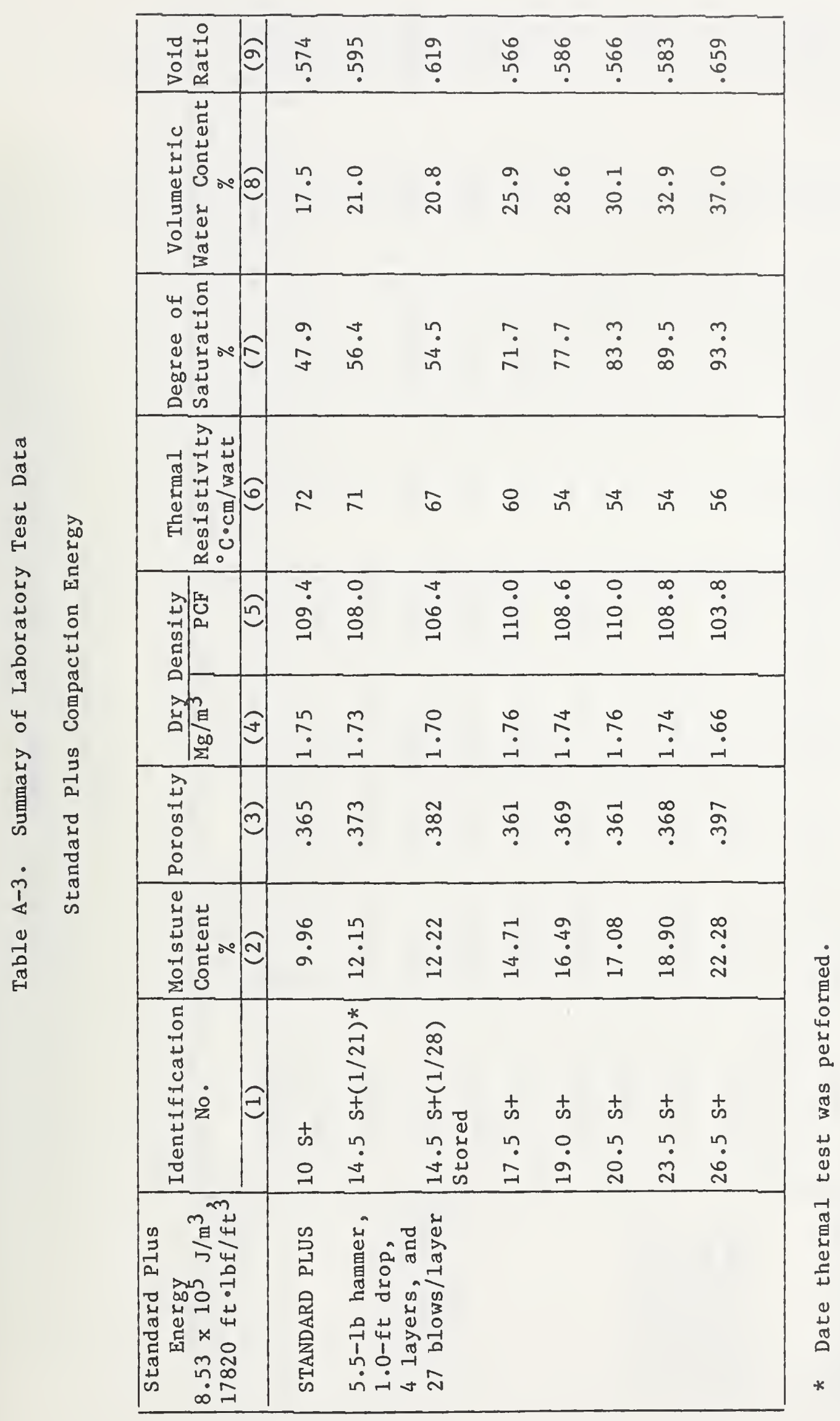




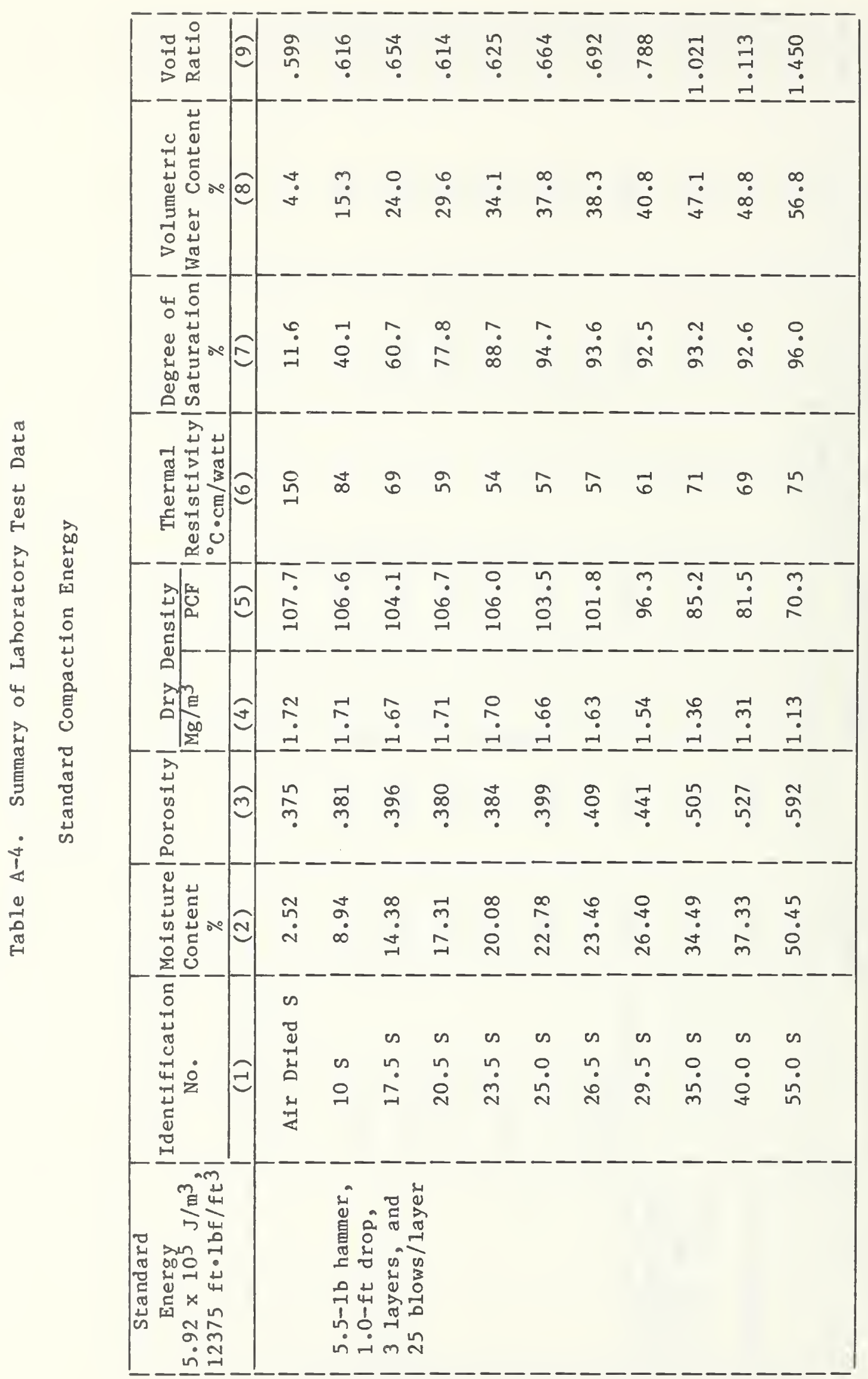




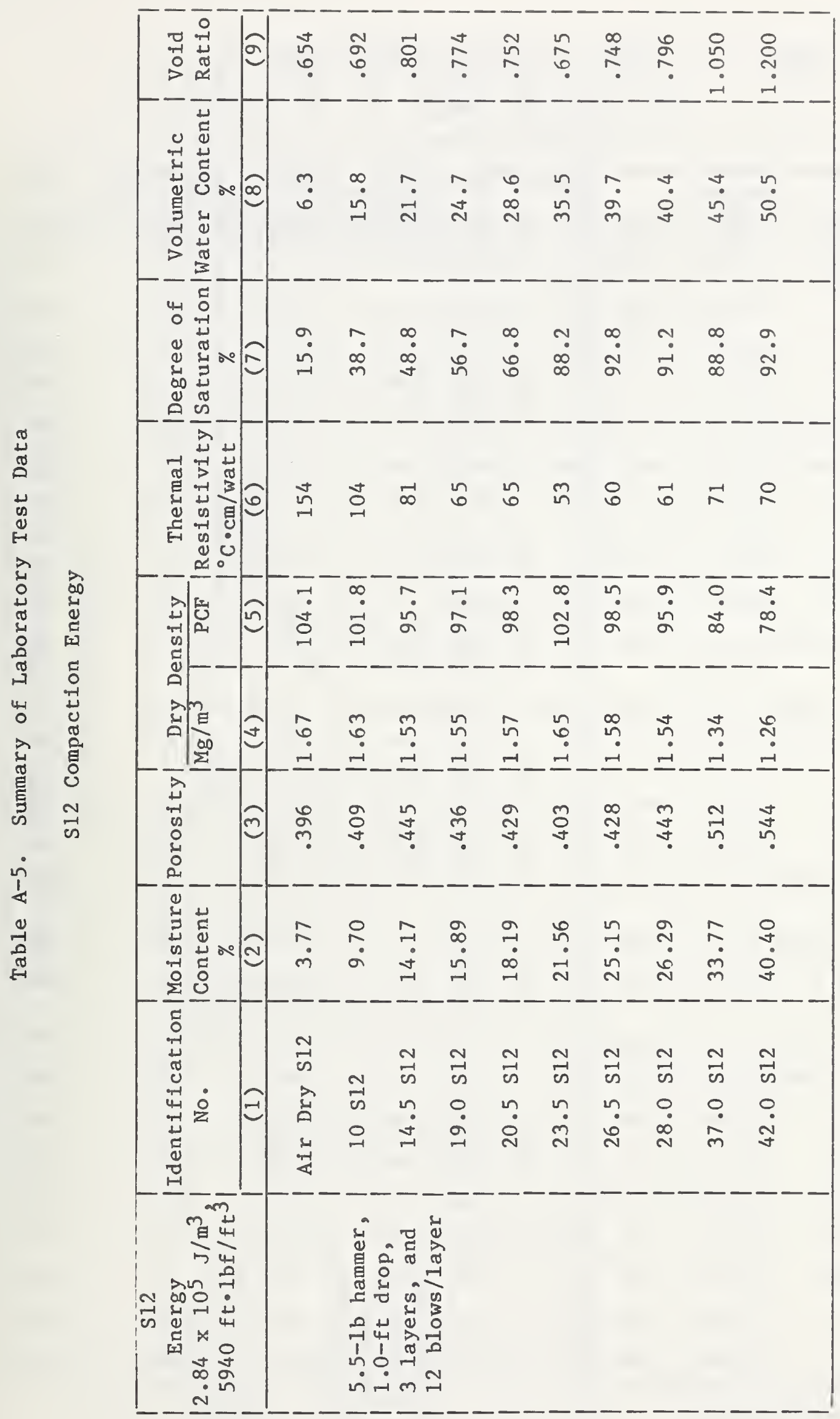


Table A-6. Summary of Laboratory Test Data

S6 Compaction Fnergy

\begin{tabular}{|c|c|c|c|c|c|c|c|c|c|}
\hline \multirow{4}{*}{\begin{tabular}{|c}
$\mathrm{S6}$ \\
Energy \\
$1.42 \times 10^{5} \mathrm{~J} / \mathrm{m}^{3}$ \\
$2970 \mathrm{ft} \cdot 1 \mathrm{bf} / \mathrm{ft}^{3}$
\end{tabular}} & \multirow{3}{*}{$\begin{array}{l}\text { Ident1fication } \\
\text { No. }\end{array}$} & \multirow{3}{*}{$\begin{array}{l}\text { | Molsture } \\
\text { |Content } \\
\mid \%\end{array}$} & \multirow{3}{*}{ Porosity } & \multirow{2}{*}{\multicolumn{2}{|c|}{ Dry Density }} & \multirow{2}{*}{ Thermal } & \multirow{2}{*}{ Degree of } & \multirow{3}{*}{$\begin{array}{l}\text { Volumetric } \\
\text { Water Content }\end{array}$} & \multirow{3}{*}{\begin{tabular}{|l|}
$\mid$ Vold \\
Rat1o
\end{tabular}} \\
\hline & & & & & & & & & \\
\hline & & & & $\mathrm{Mg} / \mathrm{m}^{3}$ & PCF & Resistivity & Saturation & & \\
\hline & (1) & (2) & (3) & (4) & (5) & (6) & $(7)$ & $(8)$ & (9) \\
\hline \multirow{27}{*}{$\begin{array}{l}5.5-1 b \text { hammer, } \\
1.0 \text {-ft drop, } \\
3 \text { layers, and } \\
6 \text { blows/layer }\end{array}$} & |A1r Dry S6 & 1.95 & .419 & 1.60 & 100.01 & 228 & 7.4 & 3.1 & .722 \\
\hline & $11.5 \mathrm{s6}$ & 10.00 & .458 & 1.50 & 93.41 & 133 & 32.7 & 15.0 & .844 \\
\hline & 11.350 & 10.00 & .430 & 11.30 & ! & 133 & 32.1 & 13.0 & .844 \\
\hline & 14.5 S6 & 12.33 & .477 & 1.44 & $90.0 \mid$ & 118 & 37.2 & 17.8 & .914 \\
\hline & 17.5 s6 & 15.55 & .473 & 1.45 & 90.71 & 84 & 47.7 & 22.6 & .899 \\
\hline & 19 s6 $(2 / 3)^{*}$ & 15.13 & .474 & 1.45 & 90.6 & 87 & 46.4 & 22.0 & .901 \\
\hline & 19 S6 $\quad(2 / 8)$ & 17.36 & .487 & 1.42 & 88.4 & 83 & 50.5 & 24.6 & .948 \\
\hline & $\begin{array}{l}20.5 \mathrm{~s} 6 \\
\text { | Stored }\end{array}$ & 16.60 & .473 & 1.45 & $90.7 \mid$ & 72 & 51.0 & 24.1 & .899 \\
\hline & $21.0 \mathrm{~s} 6$ & 18.94 & .478 & 1.44 & $89.9 \mid$ & 73 & 57.1 & 27.3 & .916 \\
\hline & 22.25 s6 & 20.10 & .476 & 1.45 & 90.31 & 71 & 61.2 & 29.1 & .907 \\
\hline & $\begin{array}{l}23.5 \text { S6 }(2 / 1) \\
\text { Stored }\end{array}$ & 20.11 & .469 & 1.46 & 91.5 & 67 & 62.9 & 29.5 & .882 \\
\hline & 23.5 s6 $(2 / 10)$ & 22.68 & .469 & 1.47 & 91.5 & 68 & 71.0 & 33.3 & .882 \\
\hline & $\begin{array}{l}23.5 \text { s6 }(2 / 12) \\
\mid \text { Stored }\end{array}$ & 20.68 & .451 & 1.51 & | $94.6 \mid$ & 66 & 69.5 & 31.4 & .821 \\
\hline & $24.75 \mathrm{~s} 6$ & 22.60 & .463 & 1.48 & $92.5 !$ & 60 & 72.4 & 33.5 & .862 \\
\hline & $25.0 \mathrm{S6}$ & 22.56 & .464 & 1.48 & $92.3 \mid$ & 63 & 71.9 & 33.4 & .866 \\
\hline & $\begin{array}{l}26.5 \text { S6 } \\
\text { Stored }\end{array}$ & 22.76 & .459 & 1.49 & 93.1 & 66 & 73.9 & 33.9 & .850 \\
\hline & 26.5 S6 $(2 / 10)$ & 24.53 & .459 & 1.49 & 93.11 & 63 & 79.6 & 36.6 & .850 \\
\hline & $\begin{array}{l}\mid 27(26.5) \quad S 6 \\
\text { Stored }\end{array}$ & 24.57 & .459 & 11.49 & 93.2 & 59 & 80.0 & 36.7 & .848 \\
\hline & 28.0 s6 $\quad(2 / 4)$ & 26.36 & .465 & 1.48 & 92.11 & 59 & 83.6 & 38.9 & .870 \\
\hline & $28.0 \leq 6 \quad(2 / 8)$ & 26.34 & .465 & 1.48 & 92.21 & 59 & 83.8 & 38.9 & .868 \\
\hline & $31.0 \mathrm{~s} 6$ & 28.64 & .468 & 1.47 & 91.61 & 66 & 89.8 & 42.0 & .880 \\
\hline & $35.0 \quad 56 / 1$ & 34.17 & .511 & 1.35 & 84.21 & 66 & 90.2 & 46.1 & 1.045 \\
\hline & $35.0 \mathrm{s6} / 2$ & 33.78 & .510 & 1.35 & 84.31 & 62 & 89.4 & 45.6 & 1.043 \\
\hline & $40.0 \mathrm{~s} 6 / 1$ & 36.94 & .532 & 1.29 & 80.61 & 61 & 89.7 & 47.7 & .137 \\
\hline & $40.0 \mathrm{~s} 6 / 2$ & 36.86 & .538 & 1.27 & 79.61 & 64 & 87.4 & 47.0 & 1.164 \\
\hline & 47.5 s6 & 41.86 & .564 & 1.20 & 75.11 & 78 & 89.4 & 50.4 & 11.293 \\
\hline & $55.0 \mathrm{~s} 6$ & 49.48 & .592 & 1.12 & $70.3 \mid$ & 80 & 94.2 & 55.8 & 1.450 \\
\hline
\end{tabular}

* Date thermal probe test was performed. 





Table A-8. Computed Values for the Zero Air Voids Curve for $G_{S}=2.76$ (100\% Saturation)

\begin{tabular}{|c|c|c|}
\hline $\begin{array}{c}\text { Moisture } \\
\text { Content } \\
\%\end{array}$ & $\begin{array}{r}\text { Dry } \\
\mathrm{Mg} / \mathrm{m}^{3}\end{array}$ & $\begin{array}{r}\text { Density } \\
\text { PCF }\end{array}$ \\
\hline (1) & (2) & (3) \\
\hline 6.8 & 2.32 & 145 \\
\hline 8.4 & 2.24 & 140 \\
\hline 10.0 & 2.16 & 135 \\
\hline 11.8 & 2.08 & 130 \\
\hline 13.7 & 2.00 & 125 \\
\hline 15.8 & 1.92 & 120 \\
\hline 18.1 & 1.84. & 115 \\
\hline 20.5 & 1.76 & 110 \\
\hline 23.2 & 1.68 & 105 \\
\hline 26.2 & 1.60 & 100 \\
\hline 29.5 & 1.52 & 95 \\
\hline 33.1 & 1.44 & 90 \\
\hline 37.2 & 1.36 & 85 \\
\hline 41.8 & 1.28 & 80 \\
\hline 47.0 & 1.20 & 75 \\
\hline 53.0 & 1.12 & 70 \\
\hline 59.8 & 1.04 & 65 \\
\hline 67.8 & 0.96 & 60 \\
\hline 77.3 & 0.88 & 55 \\
\hline 88.6 & 0.80 & 50 \\
\hline
\end{tabular}


Table A-9. Summary of Moisture Content Data

Modified Compaction Energy*

\begin{tabular}{|c|c|c|c|c|}
\hline $\begin{array}{c}\text { Identification } \\
\text { No. }\end{array}$ & $\begin{array}{c}\text { Trimmings } \\
\text { (Percent) }\end{array}$ & $\begin{array}{c}\text { Inner } \\
\text { (Percent) }\end{array}$ & $\begin{array}{c}\text { Outer } \\
\text { (Percent) }\end{array}$ & $\begin{array}{c}\text { Total } \\
\text { (Percent) }\end{array}$ \\
\hline$(1)$ & $(2)$ & $(3)$ & $(4)$ & $(5)$ \\
\hline $13.0 \mathrm{M}$ & 10.58 & -- & - & 10.96 \\
\hline $17.5 \mathrm{M}$ & 14.77 & 14.80 & 14.77 & 14.86 \\
\hline $20.5 \mathrm{M}$ & 18.46 & 17.23 & 17.34 & 17.50 \\
\hline $23.5 \mathrm{M}$ & 21.80 & 20.84 & 20.88 & 20.60 \\
\hline $25.0 \mathrm{M}$ & 23.05 & 23.10 & 22.91 & 23.03 \\
\hline $26.5 \mathrm{M}$ & 23.81 & 22.95 & 22.99 & 22.90 \\
\hline $29.5 \mathrm{M}$ & 26.17 & 26.92 & 26.59 & 26.62 \\
\hline $32.5 \mathrm{M}$ & 29.57 & 30.01 & 29.85 & 29.85 \\
\hline $35.0 \mathrm{M}$ & 34.59 & 34.90 & 34.74 & 34.57 \\
\hline $40.0 \mathrm{M}$ & 36.64 & 37.07 & 36.96 & 36.77 \\
\hline
\end{tabular}

* 10.0-1b hammer, 1.5-ft drop, 5 layers, and 25 blows/layer.

Table A-10. Summary of Moisture Content Data

Intermediate Compaction Energy*

\begin{tabular}{|c|c|c|c|c|}
\hline $\begin{array}{c}\text { Identification } \\
\text { No. }\end{array}$ & $\begin{array}{c}\text { Trimmings } \\
\text { (Percent) }\end{array}$ & $\begin{array}{c}\text { Inner } \\
\text { (Percent) }\end{array}$ & $\begin{array}{c}\text { Outer } \\
\text { (Percent) }\end{array}$ & $\begin{array}{c}\text { Total } \\
\text { (Percent) }\end{array}$ \\
\hline (1) & $(2)$ & $(3)$ & $(4)$ & $(5)$ \\
\hline Air Dried I & 2.29 & 2.89 & -- & 2.81 \\
\hline 14.5 I & 12.60 & 12.21 & -- & 12.00 \\
\hline 17.5 I & 15.61 & 15.79 & 15.52 & 15.93 \\
\hline 19.0 I & 16.63 & 16.12 & -- & 16.34 \\
\hline 20.5 I & 19.68 & 18.56 & 18.28 & 18.67 \\
\hline 23.5 I & 23.41 & 22.46 & 22.50 & 23.00 \\
\hline 25.0 I & 23.51 & 22.81 & 22.82 & 22.86 \\
\hline 26.5 I & 24.95 & 25.16 & 25.14 & 25.18 \\
\hline 29.5 I & 26.51 & 27.15 & 27.15 & 27.06 \\
\hline 32.5 I & 26.90 & 27.38 & 27.04 & 27.26 \\
\hline
\end{tabular}

* 10.0-1b hammer, 1.5-ft drop, 3 layers, and 25 blows/layer. 
Table A-11. Summary of Moisture Content Data

Standard Plus Compaction Energy*

\begin{tabular}{|c|c|c|c|c|}
\hline $\begin{array}{c}\text { Identification } \\
\text { No. }\end{array}$ & $\begin{array}{c}\text { Trimmings } \\
\text { (Percent) }\end{array}$ & $\begin{array}{c}\text { Inner } \\
\text { (Percent) }\end{array}$ & $\begin{array}{c}\text { Outer } \\
\text { (Percent) }\end{array}$ & $\begin{array}{c}\text { Total } \\
\text { (Percent) }\end{array}$ \\
\hline$(1)$ & $(2)$ & $(3)$ & $(4)$ & $(5)$ \\
\hline $10 \mathrm{St}$ & 8.28 & 9.96 & -- & 10.10 \\
\hline $14.5 \mathrm{~S}+(1 / 21)$ & - & 12.15 & 12.78 & 12.29 \\
\hline $\begin{array}{c}14.5 \mathrm{~S}+(1 / 28) \\
\text { Stored }\end{array}$ & 11.98 & 12.22 & 12.62 & - \\
\hline $17.5 \mathrm{~S}+$ & 13.69 & 14.71 & -- & 15.15 \\
\hline $19.0 \mathrm{St}$ & 16.44 & 16.49 & 16.37 & 16.87 \\
\hline $20.5 \mathrm{St}$ & 18.84 & 17.08 & -- & 17.37 \\
\hline $23.5 \mathrm{~S}+$ & 17.04 & 18.90 & 18.79 & 19.43 \\
\hline $26.5 \mathrm{~S}+$ & 23.85 & 22.28 & 22.38 & 22.93 \\
\hline
\end{tabular}

* 5.5-1b hammer, 1.0-ft drop, 4 layers, and 27 blows/layer.

Table A-12. Summary of Moisture Content Data

Standard Compaction Energy*

\begin{tabular}{|c|c|c|c|c|}
\hline $\begin{array}{c}\text { Identification } \\
\text { No. }\end{array}$ & $\begin{array}{c}\text { Trimmings } \\
\text { (Percent) }\end{array}$ & $\begin{array}{c}\text { Inner } \\
\text { (Percent) }\end{array}$ & $\begin{array}{c}\text { Outer } \\
\text { (Percent) }\end{array}$ & $\begin{array}{c}\text { Total } \\
\text { (Percent) }\end{array}$ \\
\hline (1) & $(2)$ & $(3)$ & $(4)$ & $(5)$ \\
\hline Air Dried S & 2.01 & -- & -- & 2.52 \\
\hline $10.0 \mathrm{~S}$ & 8.36 & 8.94 & -- & 8.80 \\
\hline $17.5 \mathrm{~S}$ & 15.05 & 14.38 & 14.63 & 14.97 \\
\hline $20.5 \mathrm{~S}$ & 18.60 & 17.31 & 17.36 & 17.76 \\
\hline $23.5 \mathrm{~S}$ & 20.20 & 20.08 & 19.91 & 20.30 \\
\hline $25.0 \mathrm{~S}$ & 22.02 & 22.78 & 22.49 & 22.68 \\
\hline $26.5 \mathrm{~S}$ & 23.90 & 23.46 & 23.43 & 23.66 \\
\hline $29.5 \mathrm{~S}$ & 25.19 & 26.40 & 26.46 & 26.55 \\
\hline $35.0 \mathrm{~S}$ & 33.83 & 34.49 & 34.29 & 33.87 \\
\hline $40.0 \mathrm{~S}$ & 37.96 & 37.33 & 36.96 & 37.07 \\
\hline $55.0 \mathrm{~S}$ & 50.54 & 50.45 & 50.04 & 50.86 \\
\hline
\end{tabular}

* 5.5-1b hammer, 1.0-ft drop, 3 layers, and 25 blows/layer. 
Table A13. Summary of Moisture Content Data

S12 Compaction Energy*

\begin{tabular}{|c|c|c|c|c|}
\hline Identification & Trimmings & Inner & Outer & Tota]. \\
\hline No. & (Percent) & (Percent) & (Percent) & (Percent) \\
\hline$(1)$ & (2) & (3) & (4) & $(5)$ \\
\hline Alr Dried Sl2 & 3.71 & $-\infty$ & -- & 3.77 \\
\hline $10.0 \mathrm{~S} 12$ & 8.36 & 9.70 & -- & 10.02 \\
\hline$\overline{14.5} \overline{\mathrm{S12}}$ & 14.65 & 14.17 & -- & 14.07 \\
\hline $19.0 \mathrm{~S} 12$ & 16.89 & 15.89 & 16.15 & 16.57 \\
\hline $20.5 \mathrm{S12}$ & 19.56 & 18.19 & 18.45 & 18.54 \\
\hline $23.5 \quad 512$ & 21.73 & 21.56 & 21.77 & 21.95 \\
\hline 26.5 S12 & 25.45 & 25.15 & 25.31 & 25.16 \\
\hline $28.0 \quad 512$ & 25.82 & 26.29 & 25.95 & 26.06 \\
\hline $37.0 \quad \mathrm{~S} 12$ & 33.28 & 33.77 & 33.87 & 33.80 \\
\hline $42.0 \mathrm{S12}$ & 39.51 & 40.40 & 38.68 & 38.89 \\
\hline & & & & \\
\hline
\end{tabular}

* 5.5-1b hammer, 1.0-ft drop, 3 layers, and 12 blows/layer. 
Table A-14. Summary of Moisture Content Data

S6 Compaction Energy*

\begin{tabular}{|c|c|c|c|c|}
\hline Identification & Trimmings & Inner & Outer & Total \\
\hline No. & (Percent) & (Percent) & (Percent) & (Percent) \\
\hline$(1)$ & $(2)$ & (3) & $(4)$ & (5) \\
\hline Air dry s6 & 1.97 & - & - & 1.95 \\
\hline $11.5 \quad$ S6 & 9.85 & 10.00 & 9.97 & 10.29 \\
\hline 14.5 S6 & 13.24 & 12.33 & 12.52 & 12.98 \\
\hline $17.5 \quad$ S6 & 14.89 & 15.55 & 15.45 & 15.88 \\
\hline$(2 / 3)^{* *}$ & & & & \\
\hline $19.0 \mathrm{~S} 6$ & 13.37 & 15.13 & 15.46 & 16.01 \\
\hline$(2 / 8)$ & & & & \\
\hline $19.0 \quad \mathrm{~S} 6$ & 17.68 & 17.36 & 17.56 & 17.83 \\
\hline $20.5 \quad 56$ & & & & \\
\hline Stored & 15.28 & 16.60 & 16.68 & 16.95 \\
\hline 21.0 & 19.31 & 18.94 & 19.04 & 19.36 \\
\hline $22.25 \mathrm{S6}$ & 20.16 & 20.10 & 20.06 & 20.31 \\
\hline$\overline{23.5 \text { S6 (2/1) }}$ & & & & \\
\hline Stored & 19.90 & 20.11 & 19.85 & 20.37 \\
\hline$(2 / 10)$ & & & & \\
\hline $23.5 \quad S 6$ & 22.31 & 22.68 & 22.37 & 22.50 \\
\hline $23.5 \mathrm{S6}(2 / 12)$ & & & & \\
\hline Stored & 19.48 & 20.68 & 20.48 & 20.67 \\
\hline $24.75 \quad 56$ & 22.46 & 22.60 & 22.46 & 22.74 \\
\hline 25.0 S6 & 23.07 & 22.50 & 22.45 & 22.65 \\
\hline $26.556(1 / 27)$ & & & & \\
\hline Stored & 24.53 & 22.76 & 23.44 & 23.72 \\
\hline $26 / 5$ S6 (2/10) & 23.59 & 24.53 & 24.36 & 24.42 \\
\hline $27(26.5) \mathrm{S} 6$ & & & & \\
\hline Stored & 23.98 & 24.57 & 24.74 & 24.54 \\
\hline$(2 / 4)$ & & & & \\
\hline $28.0 \quad 56$ & 26.24 & 26.36 & 26.54 & 26.33 \\
\hline$(2 / 8)$ & & & & \\
\hline $28.0 \quad S 6$ & 26.02 & 26.34 & 26.60 & 26.23 \\
\hline 31.0 S6 & 28.42 & 28.64 & 28.98 & 28.20 \\
\hline $35.0 \quad 56 / 1$ & 34.72 & 34.17 & 34.75 & 35.19 \\
\hline $35.0 \quad 56 / 2$ & 33.72 & 33.78 & 33.98 & 33.81 \\
\hline $40.0 \quad 56 / 1$ & 36.88 & 36.94 & 36.71 & 37.02 \\
\hline $40.0 \quad 56 / 2$ & 36.96 & 36.86 & 36.92 & 37.02 \\
\hline $47.5 \quad 56$ & 43.04 & 41.86 & 41.82 & 42.54 \\
\hline \multirow[t]{2}{*}{$55.0 \quad 56$} & 52.58 & 49.48 & 49.63 & 51.26 \\
\hline & & & & \\
\hline
\end{tabular}

* 5.5-1b hammer, 1.0-ft drop, 3 layers, and 6 blows/layer.

** Date thermal probe test was performed. 
Table A-15. Summary of Moisture Content Data

S4 Compaction Energy*

\begin{tabular}{|c|c|c|c|c|}
\hline $\begin{array}{c}\text { Identification } \\
\text { No. }\end{array}$ & $\begin{array}{c}\text { Trimmings } \\
\text { (Percent) }\end{array}$ & $\begin{array}{c}\text { Inner } \\
\text { (Percent) }\end{array}$ & $\begin{array}{c}\text { Outer } \\
\text { (Percent) }\end{array}$ & $\begin{array}{c}\text { Total } \\
\text { (Percent) }\end{array}$ \\
\hline$(1)$ & $(2)$ & $(3)$ & $(4)$ & $(5)$ \\
\hline $22.0 \mathrm{~S} 4$ & 21.23 & 20.30 & 20.52 & 21.14 \\
\hline $26.0 \mathrm{~S} 4$ & 24.65 & 24.87 & 24.79 & 25.08 \\
\hline $27.0 \mathrm{~S} 4$ & 25.26 & 25.74 & 26.39 & 25.78 \\
\hline $28.0 \mathrm{S4}$ & 25.28 & 25.89 & 25.92 & 25.80 \\
\hline $32.0 \mathrm{S4}$ & 30.46 & 31.30 & 31.22 & 31.38 \\
\hline
\end{tabular}

* 5.5-1b hammer, 1.0-ft drop, 3 layers, and 4 blows/layer. 
Table A-16. Moisture Loss (Gain) of the Test Samples During the Thermal Probe Test, Modified Compaction Energy*

\begin{tabular}{|c|c|c|c|c|}
\hline $\begin{array}{c}\text { Identification } \\
\text { No. }\end{array}$ & $\begin{array}{c}\text { Mass of mold and base } \\
\text { plate plus wet soil }\end{array}$ & $\begin{array}{c}\text { Moisture } \\
\text { (g) (gain) }\end{array}$ & $\begin{array}{c}\text { Percent } \\
\text { moisture } \\
\text { loss (gain) }\end{array}$ \\
\hline & $\begin{array}{c}\text { Before } \\
\text { thermal } \\
\text { probe test }\end{array}$ & $\begin{array}{c}\text { After } \\
\text { thermal }\end{array}$ & & \\
\hline$(1)$ & $(2)$ & $(3)$ & & \\
\hline $13.0 \mathrm{M}$ & 6318.8 & 6318.2 & -0.6 & -0.03 \\
\hline $17.5 \mathrm{M}$ & 6396.2 & 6395.2 & -1.0 & -0.05 \\
\hline $20.5 \mathrm{M}$ & 6389.4 & 6389.5 & -0.1 & -0.005 \\
\hline $23.5 \mathrm{M}$ & 6314.1 & 6313.5 & -0.6 & -0.03 \\
\hline $25.0 \mathrm{M}$ & 6270.2 & 6269.8 & -0.4 & -0.02 \\
\hline $26.5 \mathrm{M}$ & 6265.4 & 6265.1 & -0.3 & -0.02 \\
\hline $29.5 \mathrm{M}$ & 6169.4 & 6168.5 & -0.9 & -0.05 \\
\hline $32.5 \mathrm{M}$ & 6137.8 & 6137.1 & -0.7 & -0.04 \\
\hline $35.0 \mathrm{M}$ & 6044.8 & 6044.3 & -0.5 & -0.03 \\
\hline $40.0 \mathrm{M}$ & 6062.7 & 6063.0 & +0.3 & +0.02 \\
\hline
\end{tabular}

* 10.0-1b hammer, 1.5-ft drop, 5 layers, and 25 blows/layer.

Average loss -0.03 percent Average gain t0.02 percent 
Table A-17. Moisture Loss (Gain) of the Test Samples During the Thermal Probe Test, Intermediate Compaction Energy

\begin{tabular}{|c|c|c|c|c|}
\hline \multirow{3}{*}{$\begin{array}{c}\text { Identification } \\
\text { No. }\end{array}$} & \multirow{2}{*}{\multicolumn{2}{|c|}{$\begin{array}{c}\text { Mass of mold and base } \\
\text { plate plus wet soll } \\
\text { ( } \mathrm{g} \text { ) }\end{array}$}} & \multirow{3}{*}{\begin{tabular}{|c|} 
Moisture \\
$\mid$ loss (gain) \\
$(\mathrm{g})$
\end{tabular}} & \multirow{3}{*}{$\begin{array}{c}\text { Percent } \\
\text { moisture } \\
\text { loss (gain) }\end{array}$} \\
\hline & & & & \\
\hline & $\begin{array}{l}\text { Before } \\
\text { thermal } \\
\text { probe test }\end{array}$ & $\begin{array}{l}\text { After } \\
\text { thermal } \\
\text { probe test }\end{array}$ & & \\
\hline (1) & (2) & (3) & (4) & (5) \\
\hline Air Dried I & 6088.3 & 6087.6 & -0.7 & -0.04 \\
\hline $14.5 \mathrm{I}$ & 6297.9 & -- & -- & -- \\
\hline $17.5 \mathrm{I}$ & 6370.8 & 6370.6 & -0.2 & -0.01 \\
\hline $19.0 \mathrm{I}$ & 6355.6 & 6355.8 & +0.2 & +0.01 \\
\hline $20.5 \mathrm{I}$ & 6335.5 & 6335.3 & -0.2 & -0.01 \\
\hline $23.5 \mathrm{I}$ & 6271.0 & 6271.0 & 0.0 & 0.0 \\
\hline $25.0 \mathrm{I}$ & 6250.3 & 6249.5 & -0.8 & -0.04 \\
\hline $26.5 \mathrm{I}$ & 6209.6 & 6209.6 & 0.0 & 0.0 \\
\hline $29.5 \mathrm{I}$ & 6191.7 & 6191.3 & -0.4 & -0.02 \\
\hline $32.5 \mathrm{I}$ & 6168.4 & 6166.2 & -2.2 & -0.12 \\
\hline
\end{tabular}

* 10.0-1b hammer, 1.5-ft drop, 5 layers, and 25 blows/layer.

$$
\begin{aligned}
& \text { Average loss }-0.03 \text { percent } \\
& \text { Average gain }+0.01 \text { percent }
\end{aligned}
$$

Table A-18. Moisture Loss of the Test Samples During the Thermal

\begin{tabular}{|c|c|c|c|c|}
\hline \multirow[t]{2}{*}{$\begin{array}{c}\text { Identification } \\
\text { No. }\end{array}$} & \multicolumn{2}{|c|}{$\begin{array}{c}\text { Mass of mold and base } \\
\text { plate plus wet soll } \\
(\mathrm{g})\end{array}$} & \multirow[t]{2}{*}{$\begin{array}{c}\text { Moisture } \\
\text { Ioss (gain) } \\
\text { (g) }\end{array}$} & \multirow[t]{2}{*}{\begin{tabular}{|c|} 
Percent \\
moisture \\
loss (gain)
\end{tabular}} \\
\hline & $\begin{array}{l}\text { Before } \\
\text { thermal } \\
\text { probe test }\end{array}$ & $\begin{array}{l}\text { After } \\
\text { thermal } \\
\text { probe test }\end{array}$ & & \\
\hline (1) & $(2)$ & (3) & $(4)$ & (5) \\
\hline $10.0 \mathrm{st}$ & 6169.1 & -- & -- & -- \\
\hline$(1 / 21)^{*}$ & & & & \\
\hline $14.5 \mathrm{St}$ & 6155.3 & 6152.8 & -2.5 & -0.14 \\
\hline $14.5 \mathrm{st}$ & & & & \\
\hline Stored $(1 / 28)$ & 6159.6 & 6155.1 & -4.5 & -0.25 \\
\hline $17.5 \mathrm{st}$ & 6255.4 & 6254.8 & -0.6 & -0.03 \\
\hline $19.0 \mathrm{st}$ & 6261.9 & 6261.9 & 0.0 & 0.0 \\
\hline $20.5 \mathrm{st}$ & 6271.4 & 6268.9 & -2.5 & -0.13 \\
\hline $23.5 \mathrm{st}$ & 6305.9 & 6305.7 & -0.2 & -0.01 \\
\hline $26.5 \mathrm{st}$ & 6242.7 & 6242.0 & -0.7 & -0.04 \\
\hline
\end{tabular}
Probe Test, Standard Plus Compaction Energy

* 5.5-1b hammer, 1.0-ft drop, 4 layers, and 27 blows/layer.

** Date thermal probe test was performed.

Average loss -0.09 percent 
Table A-19. Moisture Loss (Gain) of the Test Samples During the Thermal Probe Test, Standard Compaction Energy*

\begin{tabular}{|c|c|c|c|c|}
\hline \multirow{3}{*}{ Identification } & \multirow{2}{*}{\multicolumn{2}{|c|}{$\begin{array}{l}\text { Mass of mold and base } \\
\text { plate plus wet soil } \\
(\mathrm{g})\end{array}$}} & \multirow{3}{*}{\begin{tabular}{|c|} 
Moisture \\
$\mid$ loss (gain) \\
$(\mathrm{g})$
\end{tabular}} & \multirow{3}{*}{$\begin{array}{c}\text { Percent } \\
\text { moisture } \\
\text { loss (gain) }\end{array}$} \\
\hline & & & & \\
\hline & $\begin{array}{l}\text { Before } \\
\text { thermal } \\
\text { probe test }\end{array}$ & $\begin{array}{l}\text { After } \\
\text { thermal } \\
\text { probe test }\end{array}$ & & \\
\hline (1) & (2) & (3) & (4) & (5) \\
\hline Air Dried & 5991.4 & 5989.8 & -1.6 & -0.10 \\
\hline $10 \mathrm{~s}$ & 6109.6 & 6105.1 & -4.5 & -0.25 \\
\hline $17.5 \mathrm{~s}$ & 6146.7 & 6146.7 & 0.0 & 0.0 \\
\hline $20.5 \mathrm{~s}$ & 6242.2 & 6241.9 & -0.3 & -0.02 \\
\hline $23.5 \mathrm{~s}$ & 6245.8 & 6245.9 & +0.1 & +0.005 \\
\hline $25.0 \mathrm{~s}$ & 6271.1 & 6270.6 & -0.5 & -0.03 \\
\hline $26.5 \mathrm{~s}$ & 6249.3 & 6247.8 & -1.5 & -0.08 \\
\hline $29.5 \mathrm{~s}$ & 6192.5 & 6190.6 & -1.9 & -0.10 \\
\hline $35.0 \mathrm{~S}$ & 6081.3 & 6081.0 & -0.3 & -0.02 \\
\hline $40.0 \mathrm{~s}$ & 6040.7 & 6040.8 & +0.1 & +0.006 \\
\hline $55.0 \mathrm{~s}$ & 5947.3 & 5946.6 & -0.7 & -0.04 \\
\hline
\end{tabular}

* 5.5-1b hammer, 1.0-ft drop, 3 layers, and 25 blows/layer.

Average loss -0.07 percent Average gain +0.005 percent

Table A-20. Moisture Loss of the Test Samples During the Thermal Probe Test, S12 Compaction Energy*

\begin{tabular}{|c|c|c|c|c|}
\hline \multirow{3}{*}{$\begin{array}{c}\text { Identification } \\
\text { No. }\end{array}$} & \multirow{2}{*}{\multicolumn{2}{|c|}{$\begin{array}{c}\text { Mass of mold and base } \\
\text { plate plus wet soil } \\
\text { (g) }\end{array}$}} & \multirow{3}{*}{\begin{tabular}{|c|}
$\mid$ Moisture \\
$\mid$ loss (gain) \\
$\mid$ \\
$(\mathrm{g})$
\end{tabular} \mid} & \multirow{3}{*}{$\begin{array}{c}\text { Percent } \\
\text { moisture } \\
\text { loss (gain) }\end{array}$} \\
\hline & & & & \\
\hline & $\begin{array}{l}\text { Before } \\
\text { thermal } \\
\text { probe test }\end{array}$ & $\begin{array}{l}\text { After } \\
\text { thermal } \\
\text { probe test }\end{array}$ & & \\
\hline (1) & (2) & (3) & (4) & (5) \\
\hline Air Dried S12 & 5980.2 & 5979.7 & -0.5 & -0.03 \\
\hline $10.0 \mathrm{~S} 12$ & 6036.0 & 6035.2 & -0.8 & -0.05 \\
\hline $14.5 \quad 512$ & 6001.2 & 6000.6 & -0.6 & -0.04 \\
\hline $19.0 \mathrm{~S} 12$ & 6020.9 & 6020.6 & -0.3 & -0.02 \\
\hline $20.5 \quad S 12$ & 6102.3 & 6102.4 & -0.1 & -0.006 \\
\hline 23.5 S12 & 6240.0 & 6239.6 & -0.4 & -0.02 \\
\hline 26.5 s12 & 6185.0 & 6184.9 & -0.1 & -0.005 \\
\hline $28.0 \quad \mathrm{~S} 12$ & 6179.1 & 6179.1 & 0.0 & 0.0 \\
\hline $37.0 \quad 512$ & 6044.8 & 6044.7 & -0.1 & -0.006 \\
\hline $42.0 \quad \mathrm{~S} 12$ & 6009.9 & 6009.3 & -0.6 & -0.01 \\
\hline & & & & \\
\hline
\end{tabular}

* 5.5-1b hammer, 1.0-ft drop, 3 layers, and 12 blows/layer. Average loss -0.02 percent 
Table A-21. Moisture Loss (Gain) of the Test Samples During the Thermal Probe Test, S6 Compaction Energy*

\begin{tabular}{|c|c|c|c|c|}
\hline \multirow[t]{2}{*}{$\begin{array}{c}\text { Identification } \\
\text { No. }\end{array}$} & \multicolumn{2}{|c|}{$\begin{array}{l}\text { Mass of mold and base } \\
\text { plate plus wet soil } \\
\text { (g) }\end{array}$} & \multirow[t]{2}{*}{$\begin{array}{c}\text { Moisture } \\
\text { 1oss (gain) } \\
\text { (g) }\end{array}$} & \multirow[t]{2}{*}{$\begin{array}{c}\text { Percent } \\
\text { moisture } \\
\text { loss (gain) }\end{array}$} \\
\hline & $\begin{array}{l}\text { Before } \\
\text { thermal } \\
\text { probe test }\end{array}$ & $\begin{array}{l}\text { After } \\
\text { thermal } \\
\text { probe test }\end{array}$ & & \\
\hline (1) & (2) & (3) & (4) & (5) \\
\hline $\begin{array}{l}\text { Air } \\
\text { Dried S6 }\end{array}$ & 5885.3 & 5884.9 & -0.4 & -0.03 \\
\hline $11.5 \quad \mathrm{~S} 6$ & 5899.5 & 5898.4 & -1.1 & -0.07 \\
\hline 14.5 S6 & 5876.0 & 5875.4 & -0.6 & -0.04 \\
\hline $17.5 \quad \mathrm{~S} 6$ & 5905.0 & 5903.9 & -1.1 & -0.07 \\
\hline $19.0 \mathrm{~S} 6^{(2 / 3)^{\frac{1}{*} *}}$ & 5897.2 & 5896.8 & -0.4 & -0.03 \\
\hline $19.0 \mathrm{S6}^{(2 / 8)}$ & 5888.2 & 5887.2 & $-1 \cdot 0$ & -0.06 \\
\hline $\begin{array}{l}20.5 \text { S6 } \\
\text { Stored }\end{array}$ & 5919.0 & 5918.8 & -0.2 & -0.01 \\
\hline 21.0 s6 & 5961.0 & 5961.3 & +0.3 & +0.02 \\
\hline $22.25 \mathrm{~s} 6$ & 5959.1 & 5959.3 & +0.2 & +0.01 \\
\hline $\begin{array}{l}23.5 \text { S6 (2/1) } \\
\text { Stored }\end{array}$ & 6007.1 & 6007.1 & 0.0 & 0.0 \\
\hline $23.5 \quad 56^{(2 / 10)}$ & 6045.6 & 6045.3 & $=-0.3$ & -0.02 \\
\hline $\begin{array}{l}23.5 \text { S6 }(2 / 12) \\
\text { Stored }\end{array}$ & 6073.3 & 6073.2 & -0.1 & -0.006 \\
\hline $24.75 \mathrm{~s} 6$ & 6062.8 & 6062.4 & -0.4 & -0.02 \\
\hline $25.0 \quad \mathrm{~s} 6$ & 6030.6 & 6030.3 & -0.3 & -0.02 \\
\hline $\begin{array}{l}25.0 \text { S6 }(1 / 27) \\
\text { Stored }\end{array}$ & 6077.6 & 6077.4 & -0.2 & -0.01 \\
\hline 26.5 S6 $^{(2 / 10)}$ & $6072 \cdot 3$ & 6072.6 & +0.3 & +0.02 \\
\hline $\begin{array}{l}27(26.5) \text { S6 } \\
\text { Stored }\end{array}$ & 6099.6 & 6099.5 & -0.1 & -0.006 \\
\hline 28.0 S6 $^{(2 / 4)}$ & 6079.5 & 6079.4 & -0.1 & -0.006 \\
\hline 28.0 s6 & 6110.2 & 6110.1 & -0.1 & -0.006 \\
\hline $31.0 \quad \mathrm{~s} 6$ & 6132.8 & 6131.1 & -1.7 & -0.09 \\
\hline $35.0 \mathrm{~s} 6 / 1$ & 6052.0 & 6051.7 & -0.3 & -0.02 \\
\hline $35.0 \mathrm{~s} 6 / 2$ & 6050.4 & 6049.7 & -0.7 & -0.04 \\
\hline $40.0 \mathrm{~s} 6 / 1$ & 5988.7 & 5988.5 & -0.2 & -0.01 \\
\hline $40.0 \quad \mathrm{~S} 6 / 2$ & 5967.3 & 5966.8 & -0.5 & -0.03 \\
\hline 47.5 S6 & 5930.1 & 5929.3 & -0.8 & -0.05 \\
\hline 55.0 S6 & 5908.2 & 5907.4 & -0.8 & -0.05 \\
\hline
\end{tabular}

* 5.5-1b hammer, 1.0-ft drop, 3 layers, and 6 blows/layer.

** Date thermal probe test was performed

Average loss -0.03 percent

Average gain +0.02 percent 
Table A-22. Moisture Loss of the Test Samples During the Thermal Probe Test, 54 Compaction Energy

\begin{tabular}{|c|c|c|c|c|}
\hline \multirow[t]{2}{*}{$\begin{array}{c}\text { Identification } \\
\text { No. }\end{array}$} & \multicolumn{2}{|c|}{$\begin{array}{c}\text { Mass of mold and base } \\
\text { plate plus wet soil } \\
\text { (g) }\end{array}$} & \multirow[t]{2}{*}{$\begin{array}{c}\text { Moisture } \\
\text { loss } \\
\text { (g) }\end{array}$} & \multirow[t]{2}{*}{$\begin{array}{l}\text { Percent } \\
\text { moisture } \\
\text { loss }\end{array}$} \\
\hline & $\begin{array}{l}\text { Before } \\
\text { thermal } \\
\text { probe test }\end{array}$ & $\begin{array}{l}\text { After } \\
\text { thermal } \\
\text { probe test }\end{array}$ & & \\
\hline (1) & (2) & (3) & (4) & (5) \\
\hline 22.0 S4 & 5932.5 & 5932.3 & -0.2 & -0.01 \\
\hline 26.0 & 6083.6 & 6083.3 & -0.3 & -0.02 \\
\hline 27.0 & 6011.6 & 6010.6 & -1.0 & -0.06 \\
\hline 28.0 & 5978.1 & 5977.8 & -0.3 & -0.02 \\
\hline $32.0 \quad$ S4 & 6052.1 & 6051.8 & -0.3 & -0.02 \\
\hline
\end{tabular}

* 5.5-1b hammer, 1.0-ft drop, 3 layers, and 4 blows/layer. Average loss -0.03 percent 




10. SUPPLEMENTARY NOTES

Library of Congress Catalog Card Number: 82-600636

[Document describes a computer program; SF-185, FIPS Software Summary, is attached.

11. ABSTRACT (A 200-word or less factual summary of most significant information. If document includes a significant bibliogrophy or literoture survey, mention it here)

Laboratory thermal probe tests performed on an AASHTO standard reference material (a silty clay) showed that thermal resistivity $\left({ }^{\circ} \mathrm{C} \cdot \mathrm{cm} /\right.$ watt) varies with soil moisture content and dry density. The tests were performed to correlate soil thermal behavior with the limit states of fine-grained soils. Over 80 thermal resistivity measurements were made on specimens compacted to various densities and moisture contents.

Results are presented which indicate that the optimum moisture content of soils and the Atterberg Limits can be correlated with the thermal behavior of finegrained soils. It was found that the minimum thermal resistivity (i.e., the critical moisture content) occurred at the optimum moisture content when the soils were compacted using various compactive efforts. The critical moisture content defines the knee of the thermal resistivity versus moisture content curye. When the soils were compacted using a compactive effort of $1.42 \times 10^{5}$ $\mathrm{J} / \mathrm{m}^{3}$ (2970 ft-1bs per cubic foot), the minimum thermal resistivity occurred at the plastic limit of the AASHTO standard reference material. Also, indices are defined which allow comparison of the thermal behavior of fine-grained soils.

12. KEY WORDS (Six to twelve entries; alphabetical order; capitalize only proper names; and separate key words by semicolons)

Atterberg Limit tests; compaction; compaction tests; heat flow; laboratory tests; soil moisture; soil tests; tests; thermal conductivity; thermal resistivity

13. AVAILABILITY

[X] Unlimited

$\square$ For Official Distribution. Do Not Release to NTIS

[X] Order From Superintendent of Documents, U.S. Government Printing Office, Washington, D.C. 20402.

[ Order From National Technical Information Service (NTIS), Springfield, VA. 22I6I

14. NO. OF

PRINTED PAGES

102

15. Price

$\$ 5.50$ 



\section{NBS TECHNICAL PUBLICATIONS}

\section{PERIODICALS}

JOURNAL OF RESEARCH-The Journal of Research of the National Bureau of Standards reports NBS research and development in those disciplines of the physical and engineering sciences in which the Bureau is active. These include physics, chemistry, engineering, mathematics, and computer sciences. Papers cover a broad range of subjects, with major emphasis on measurement methodology and the basic technology underlying standardization. Also included from time to time are survey articles on topics closely related to the Bureau's technical and scientific programs As a special service to subscribers each issue contains complete citations to all recent Bureau publications in both NBS and nonNBS media. Issued six times a year. A nnual subscription: domestic $\$ 18$; foreign $\$ 22.50$. Single copy, $\$ 4.25$ domestic; $\$ 5.35$ foreign.

\section{NONPERIODICALS}

Monographs-Major contributions to the technical literature on various subjects related to the Bureau's scientific and technical activities.

Handbooks-Recommended codes of engineering and industrial practice (including safety codes) developed in cosperation with interested industries, professional organizations, and regulatory bodies.

Special Publications-Include proceedings of conferences sponsored by NBS, NBS annual reports, and other special publications appropriate to this grouping such as wall charts, pocket cards, and bibliographies.

Applied Mathematics Series-Mathematical tables, manuals, and studies of special interest to physicists, engineers, chemists, biologists, mathematicians, computer programmers, and others engaged in scientific and technical work.

National Standard Reference Data Series-Provides quantitative data on the physical and chemical properties of materials, compiled from the world's literature and critically evaluated Developed under a worldwide program coordinated by NBS under the authority of the National Standard Data Act (Public Law 90-396).

NOTE: The principal publication outlet for the foregoing data is the Journal of Physical and Chemical Reference Data (JPCRD) published quarterly for NBS by the American Chemical Society (ACS) and the American Institute of Physics (AIP). Subscriptions, reprints, and supplements available from ACS, 1155 Sixteenth St. NW, Washington, DC 20056
Building Science Series-Disseminates technical information developed at the Bureau on building materials, components, systems, and whole structures. The series presents research results, test methods, and performance criteria related to the structural and environmental functions and the durability and safety characteristics of building elements and systems.

Technical Notes-Studies or reports which are complete in themselves but restrictive in their treatment of a subject. Analogous to monographs but not so comprehensive in scope or definitive in treatment of the subject area. Often serve as a vehicle for final reports of work performed at NBS under the sponsorship of other government agencies.

Voluntary Product Standards-Developed under procedures published by the Department of Commerce in Part 10, Title 15, of the Code of Federal Regulations. The standards establish nationally recognized requirements for products, and provide all concerned interests with a basis for common understanding of the characteristics of the products. NBS administers this program as a supplement to the activities of the private sector standardizing organizations.

Consumer Information Series-Practical information, based on NBS research and experience, covering areas of interest to the consumer. Easily understandable language and illustrations provide useful background knowledge for shopping in today's technological marketplace

Order the above NBS publications from: Superintendent of Documents, Government Printing Office, Washington, DC 20402.

Order the following NBS publications-FIPS and NBSIR's-from the National Technical Information Services. Springfield, VA 22161.

Federal Information Processing Standards Publications (FIPS PUB)-Publications in this series collectively constitute the Federal Information Processing Standards Register. The Register serves as the official source of information in the Federal Government regarding standards issued by NBS pursuant to the Federal Property and Administrative Services Act of 1949 as amended. Public Law 89-306 (79 Stat. 1127), and as implemented by Executive Order 11717 (38 FR 12315, dated May 11, 1973) and Part 6 of Title 15 CFR (Code of Federal Regulations).

NBS Interagency Reports (NBSIR) - A special series of interim or final reports on work performed by NBS for outside sponsors (both government and non-government). In general, initial distribution is handled by the sponsor: public distribution is by the National Technical Information Services, Springfield, VA 22161 . in paper copy or microfiche form. 
U.S. Department of Commerce

National Bureau of Standards

Washington, D.C. 20234

Official Business

U.S.MAIL

Penalty for Private Use $\$ 300$

OSTAGE AND FEES PAID U.S. DEPARTMENT OF COMMERCE COM-215

THIRD CLASS BULK RATE 